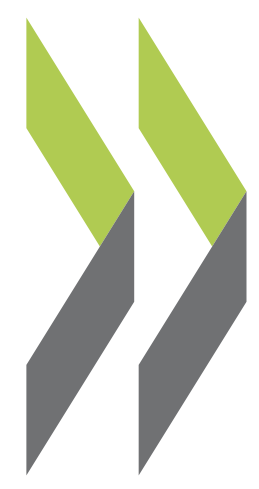

OECD Economics Department Working Papers No. 430

Fifteen Years of Economic Reform in Russia: What has been Achieved? What Rudiger Ahrend, Remains to be Done? 
Organisation de Coopération et de Développement Economiques

Organisation for Economic Co-operation and Development

ECONOMICS DEPARTMENT

English - Or. English

FIFTEEN YEARS OF ECONOMIC REFORM IN RUSSIA: WHAT HAS BEEN ACHIEVED? WHAT REMAINS TO BE DONE?

ECONOMICS DEPARTMENT WORKING PAPERS No. 430

By Rudiger Ahrend and William Tompson

All Economics Department Working Papers are now available throught the OECD Internet Web site at www.oecd.org/eco. 


\section{Abstract \\ Fifteen years of economic reform in Russia: what has been achieved? What remains to be done?}

The paper provides an overview of the course of economic reform and the performance of the Russian economy since the early 1990s and an analysis of the structural reform challenges ahead. It assesses the contribution of institutional and structural reforms to economic performance over the period, before turning to the question of where further structural reforms could make the biggest contribution to improved performance. Three major conclusions emerge. First, there is still a great deal to be done to strengthen the basic institutions of the market economy. While the Russian authorities have embarked on some impressive - and often technically complex - 'second-generation' reforms, many 'first-generation' reforms have yet to be completed. Secondly, the central challenges of Russia's second decade of reform are primarily concerned with reforming state institutions. Thirdly, the pursuit of reforms across a broad front could enable Russia to profit from complementarities that exist among various strands of reform.

JEL Classification: H1; K2; P21; P26; P27; P31; P37; P48.

Keywords: Russia; economy; reform; growth; stabilisation; transparency; corruption; state ownership; competition; transition.

***

\section{Résumé}

Quinze ans de réformes économiques en Russie : Qu'a-t-elle acquis ? Que reste-t-il à faire ?

L'article donne un aperçu du déroulement des réformes économiques et des performances de l'économie russe depuis le début des années 90, ainsi qu'une analyse des enjeux des futures réformes structurelles. L'article considère la contribution des réformes institutionnelles et structurelles à la performance économique durant la période, avant d'examiner dans quels domaines des réformes structurelles additionnelles pourraient avoir la plus grande contribution à l'amélioration de la performance économique. Il en résulte trois conclusions majeures. Premièrement, il reste encore beaucoup à faire pour renforcer les institutions de base d'une économie de marché. Bien que les autorités russes aient commencé quelques réformes de «seconde génération» qui sont impressionnantes - et souvent techniquement complexes-, il reste un bon nombre de réformes de «première génération » à achever. Deuxièmement, les défis centraux de la deuxième décennie de réformes concernent en première ligne la réforme des institutions de l'État. Troisièmement, la poursuite des réformes sur un large front permettrait à la Russie de profiter des complémentarités existantes entre les différents axes des réformes.

Classification JEL: H1 ; K2 ; P21 ; P26 ; P27 ; P31 ; P37 ; P48.

Mots clés: Russie; économie ; réforme; croissance; stabilisation; transparence ; corruption; entreprises d'État ; concurrence.

\section{Copyright OECD, 2005}

Application for permission to reproduce or translate all, or part of, this material should be made to: Head of Publications Service, OECD, 2 rue André Pascal, 75775 Paris Cedex 16, France. 


\section{TABLE OF CONTENTS}

\section{FIFTEEN YEARS OF ECONOMIC REFORM IN RUSSIA: WHAT HAS BEEN ACHIEVED?

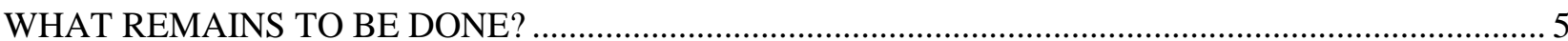

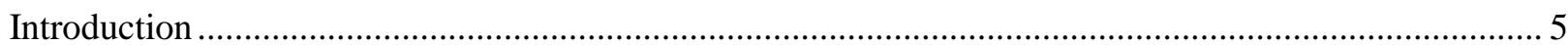

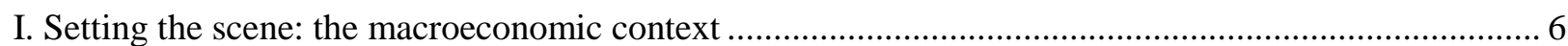

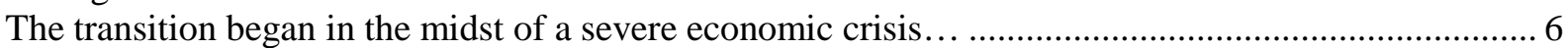

... which prompted the authorities to opt for a 'big bang' approach to reforms ................................. 7

The initial reform package was followed by several years of high inflation and falling output ........... 10

An exchange-rate-based stabilisation strategy reduced inflation but at a very high price..................... 12

The period of the 'rouble corridor' coincided with Russia's most controversial privatisation sales..... 14

The Asian crisis and falling commodity prices finally rendered the situation unsustainable ................ 15

The post-crisis recovery began sooner and has lasted longer than most observers expected................ 16

High prices and apparent security of property rights contributed to an oil-sector boom...................... 17

Prudent fiscal policies helped to sustain the recovery............................................................... 18

...while monetary policy has struggled to balance inflation and exchange-rate concerns .................... 18

Russian industry has raised productivity rapidly since the crisis ...................................................... 19

The post-crisis expansion has coincided with a period of renewed structural reform ........................... 21

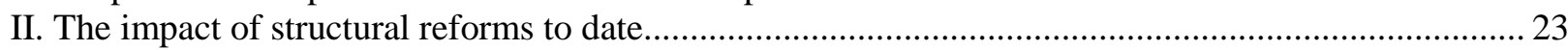

More than a decade of transformation has transformed the structure of ownership............................. 23

....as well as the structure of production, employment and foreign trade ........................................... 24

Price liberalisation, though painful, has brought significant benefits.................................................. 27

Liberalisation of foreign trade and FDI has benefited consumers and increased competition .............. 28

Russia's privatisation policies have attracted much criticism ............................................................ 30

Nevertheless, the evidence suggests that privatisation has improved enterprise performance.............. 32

Financial sector development has so far produced only limited benefits to the economy as a whole... 34

Russia's experience shows both the benefits of competition and the need for stronger competition

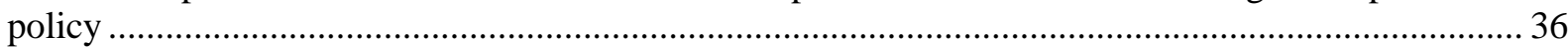

Judicial reforms have ended some abusive legal practices but the administration of law remains

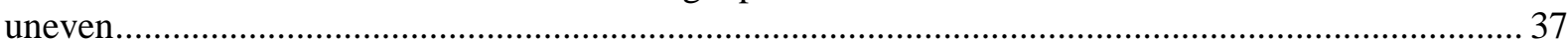

The law on technical regulation is potentially a major step forward for regulatory governance .......... 37

'De-bureaucratisation' legislation has helped to reduce the bureaucratic burden on private firms....... 38

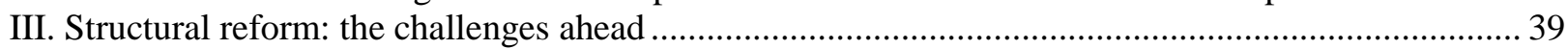

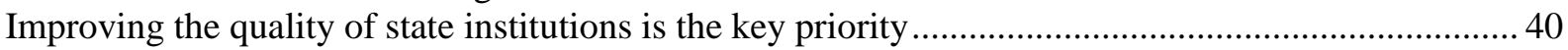

The reform of federal executive bodies got off to a rocky start............................................................. 41

Civil service reform is likely to prove an even greater challenge......................................................... 41

The Russian bureaucracy has undergone massive change, but little reform since 1991 ....................... 43

There is still little clarity concerning the strategic direction of civil service reform .............................. 44

Changes in the broader institutional environment will be crucial to the success of civil service

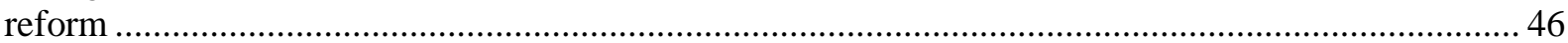

An effective anti-corruption strategy will of necessity be multi-faceted............................................. 48

Judicial reform is far from complete and much remains to be done to establish the rule of law........... 49

Greater coherence is needed in the application of rules across all levels of government.......................50

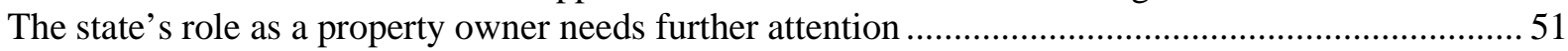


Further privatisation will help relieve the state of the burden of unwanted assets 51

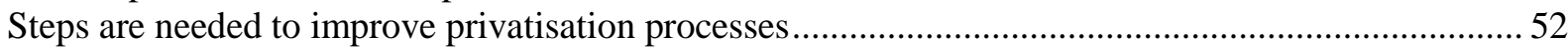

The governance of companies destined to remain in state ownership needs to be re-examined...........52

More needs to be done to curb the role of officials in the day-to-day activities of private firms.......... 53

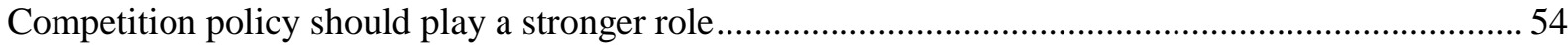

There are complementarities between stronger competition policy and better corporate governance.. 55

Many sectors would benefit from a relaxation of restrictions on foreign investment ........................... 56

Steps are needed to reform sectors dominated by state-controlled monopolies .................................... 57

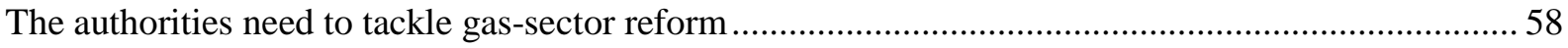

Better regulation of the financial sector will help foster the development of real financial

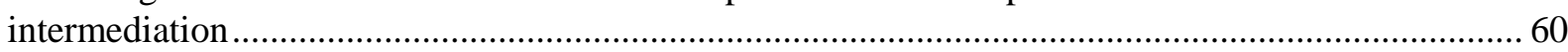

Banking reform will test both the political will and the regulatory capacities of the authorities .......... 60

More needs to be done to reduce the state's role in the provision of banking services..........................6 60

Financial markets need better sector-specific regulation and better framework conditions.................. 61

The financial sector would also benefit from the removal of the remaining barriers to foreign entry .. 62

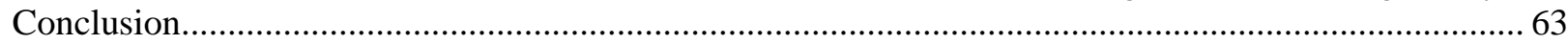

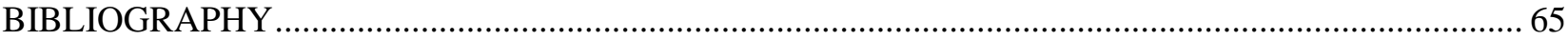

\section{Boxes}

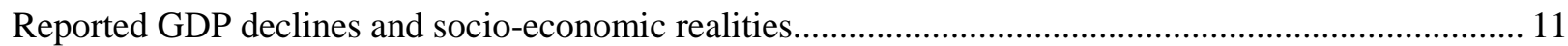

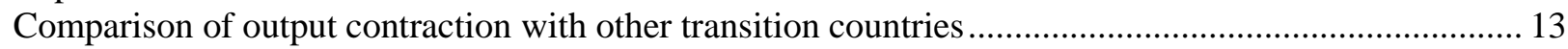

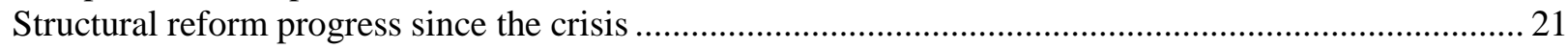

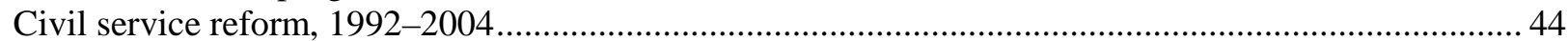

\section{List of Tables}

1. Basic economic indicators

2. Banking sector development in selected economies

\section{List of Figures}

1. Real GDP growth

2. Oil sector companies: relative performance

3. Labour productivity: changes in the 30 most important industrial sectors

4. The composition of industrial productivity growth

5. Structure of GDP

6. Structure of Exports, 2003 
ECO/WKP(2005)17

\title{
FIFTEEN YEARS OF ECONOMIC REFORM IN RUSSIA: WHAT HAS BEEN ACHIEVED? WHAT REMAINS TO BE DONE?
}

\author{
Rudiger Ahrend and William Tompson ${ }^{1}$
}

\section{Introduction}

The present paper provides a broad overview of the course of economic reform and the performance of the Russian economy since the onset of the market transformation and an analysis of the structural reform challenges that still lie ahead. ${ }^{2}$ The discussion begins with an analysis of economic policy and performance since the early 1990s. It then considers the contribution that institutional and structural reforms have made to recent performance, before turning to the question of where further structural reform would facilitate improved economic performance. Three major conclusions emerge from the analysis:

- There is still a great deal to be done to strengthen the basic institutions and framework conditions for the market economy. Establishing the rule of law and the security of property rights, increasing the transparency and accountability of state institutions, and combating corruption all remain critical priorities. While the Russian authorities have embarked on some impressive - and often technically complex - 'second-generation' reforms in fields such as electricity restructuring, many 'first-generation' reforms have yet to be completed.

- The central challenges of Russia's second decade of reform are primarily concerned with the reform of state institutions. Among the main tasks ahead are the civil service reform, judicial reform and the creation of new regulatory institutions and new forms of regulation better suited the needs of a market economy.

- The pursuit of reforms across a broad front could enable Russia to benefit from the complementarities that exist among various strands of reform. In a number of spheres, seemingly unrelated reforms are actually mutually reinforcing, sometimes in unexpected ways. Thus, there would appear to be synergies between reforms in such seemingly diverse spheres as corporate governance and competition policy or judicial reform and financial regulation. In such cases, the returns generated by implementing two or more reforms in tandem could exceed the sum of those that would be realised if each were pursued separately.

1. Economics Department, OECD, 2 rue André Pascal, 75775 Paris CEDEX 16, France; rudiger.ahrend@oecd.org or william.tompson@oecd.org. This paper is based on work done in conjunction with the OECD Regulatory Reform Review of the Russian Federation, and the authors are grateful to the many Russian and western officials, experts and businessmen, too numerous to list here by name, who discussed economic and regulatory reform issues with them. Special thanks go to Corinne Chanteloup for technical assistance, as well as to Muriel Duluc for secretarial assistance. The opinions expressed in the paper are theirs and do not necessarily reflect the views of the OECD or its member states.

2. As this paper has been prepared in conjunction with the OECD Regulatory Reform Review of Russia, it places special emphasis on characteristics of the economy of particular relevance to regulatory reform. 
The last of these three points is closely related to the former two, in so far as many of the reform complementarities addressed in the paper refer to the dependence of 'second generation' reforms on improvements in the functioning of state institutions and in the basic institutions of the market economy.

\section{Setting the scene: the macroeconomic context}

The macroeconomic context for structural reform in Russia has been defined by the post-communist transformation of the country's political and economic systems. It is critical to appreciate the dual nature of this transition. When Russia embarked on its transition to the market in January 1992, it had just emerged as an independent country from the break-up of the Soviet Union. While it inherited many of the structures of the now defunct Soviet state, the new Russia still lacked certain attributes conventionally associated with statehood. It had neither its own currency nor control over its borders, and it was unable to perform such basic functions as tax collection. Subnational governments openly defied the centre, while central bureaucracies were in turmoil. The transition to a more democratic form of government was still in its early stages, and many of the institutions and other structures inherited from the Soviet Union were singularly ill suited to the needs of Russia's democratic and market transitions. The last thirteen years have therefore been about reconstructing the state no less than about marketisation.

\section{The transition began in the midst of a severe economic crisis...}

Any analysis of Russia's market transformation must begin with the terminal crisis of the Soviet system. It is crucial to understand the situation facing the Russian Federation when it emerged as a newly independent state and embarked on radical economic reforms in the wake of the Soviet collapse. While this crisis had its roots in the long-term secular decline in growth rates experienced by the USSR from the 1950s onwards, the final breakdown of the Soviet command economy was precipitated by a combination of external shocks, ${ }^{3}$ ill conceived reforms and growing political unrest. The half-hearted economic reforms of the late 1980s, which aimed to introduce some market efficiencies into the Soviet system, merely made matters worse: they undermined many of the traditional structures and disciplines of the command economy without putting anything effective in their place.

By 1991, the polity was fragmenting and the economy was in free-fall. Real GDP that year dropped by somewhere between 8 and 17 per cent - estimates vary widely, owing to the chaotic economic and political situation of the time. ${ }^{4}$ Rising subsidies to back controlled prices, falling production and collapsing tax discipline pushed the Soviet state budget deficit above 16 per cent of GDP. Since this deficit could only be financed by printing money, the money supply ballooned, wrecking what remained of the system of price controls. Although the Soviet authorities continued to shy away from price liberalisation, wholesale price inflation in 1991 reached 138.1 per cent and retail price inflation 90.4 per cent; food prices jumped 112 per cent. The combination of price-controls and monetary incontinence meant that very high inflation coexisted with the shortages produced by price controls. ${ }^{6}$ The external picture was equally dismal. Exports in 1991 fell by 40 per cent in dollar terms and imports by 80 per cent. The Soviet external debt

3. These included the Chernobyl nuclear accident, the international oil price collapse of 1986, and a sharp decline in the value of the dollar in 1986-87. Chernobyl, in addition to its enormous human cost, arguably wrecked the $12^{\text {th }}$ Five-Year Plan. The oil price drop represented a major terms of trade shock, while the decline of the dollar merely aggravated this effect, since Soviet exports were generally priced in dollars but most imports were invoiced in West European currencies, particularly the Deutschmark.

4. Granville (1995:14); see also Ericson (1995:37).

5. Sinel'nikov (1995:20). It reached 26 per cent according to the IMF's calculations; see IMF (1992).

6. Fewer than a dozen of the 130 goods considered by the statistical authorities to be basic necessities for everyday life were available through normal retail channels by late 1991 . 
reached $\$ 67 \mathrm{bn}$ - roughly 566 per cent of rouble GDP at the market exchange rate. Foreign exchange reserves fell to $\$ 60 \mathrm{~m}$, around 10 hours' import cover - a product of western insistence that Russia service its debts until a restructuring could be agreed. An appreciation of these conditions is crucial to understanding why the early stages of the transition unfolded as they did.

\section{... which prompted the authorities to opt for a 'big bang' approach to reforms}

Faced with such an acute crisis, the Russian authorities at the end of 1991 concluded that they must act decisively and without delay. They opted for a 'big bang' approach to economic transformation, involving the rapid implementation of price and trade liberalisation, as well as large-scale privatisation. Critics have argued the public and the elite would have been more open to a gradualist approach, employing the traditional instruments of the old system, like administered price rises and rationing, to stabilise the situation before proceeding with reforms. However, given the erosion of central authority and the decay of Soviet economic institutions, it was not at all clear that such an approach was feasible, let alone desirable. The system of fixed prices had largely collapsed and it is doubtful whether even the most determined cabinet could have re-imposed wide-ranging price controls and ensured supplies of goods at official prices in sufficient quantities for the system to have any credibility. On 2 January 1992, therefore, some 90 per cent of retail and 80 per cent of producer prices were freed. The main exceptions were energy, some raw materials and some basic foodstuffs. At the same time, the government moved quickly towards external liberalisation. The state foreign trade monopoly was abolished, and quantitative controls on imports were scrapped in January. A flat 5 per cent import tariff was adopted in July.

These measures were accompanied by drastic cuts in federal spending, particularly on such previously sacrosanct items as defence procurement. Fiscal tightening was to be accompanied by tight monetary policies in an effort to ensure that, once the relative price adjustments set in train by liberalisation had taken place and the excess rouble liquidity generated in the late Soviet era had been absorbed, prices would stabilise at their new levels. Soon after prices were freed, the rapid privatisation of state property was undertaken, initially via a voucher scheme that was meant to enable virtually the whole of the country's adult population to become asset owners on at least a small scale. Rapid privatisation was intended to create a broad class of share owners who, having acquired a stake in the system, would support further reforms. It was also meant to separate economic and political decision-making and thereby to cut failing enterprises off from the state budget. Ultimately, the intention was to foster the emergence of a population of real sink-or-swim firms whose managers would have incentives to use resources efficiently. In any case, rapid privatisation was seen as a necessity in part because a process of spontaneous privatisation was already well under way. ${ }^{7}$ One of the government's chief priorities in this sphere was to regain a measure of control over that process. When the voucher phase ended in mid-1994, the state's average holding had fallen to 38 per cent across all industrial firms (including those not privatised at all to mid-1994) and an average of just 15 per cent in privatised enterprises. According to Goskomstat data, 57.9 per cent of the workforce (including 76 per cent of the industrial workforce) was employed in privatised or new private firms. Over 70 per cent of small-scale enterprises had been transferred to private ownership.

Political realities imposed limits on all three major strands of reform:

- After the initial shock of the January 1992 liberalisation package, price liberalisation actually proceeded relatively slowly, as many regional authorities feared the popular response to any rapid elimination of price controls on basic necessities, while the federal government feared the impact on industry of liberalising energy prices.

7. See Solnick (1998) and Rosefielde and Hedlund (2004). 
- Trade liberalisation was also far from complete. Exports of many commodities (most notably oil) were subject to quotas or very high export duties in an effort to hold down domestic prices. Numerous controls on imports remained, alongside subsidised imports of some necessities. Such controls appeased certain domestic constituencies and also created lucrative opportunities for those administering them.

- The authorities were able to proceed with voucher privatisation only after amending the legislation to grant special privileges to enterprise insiders (managers and labour collectives), thereby ensuring that most enterprises would emerge from the process with a dispersed and insider-oriented ownership structure. 


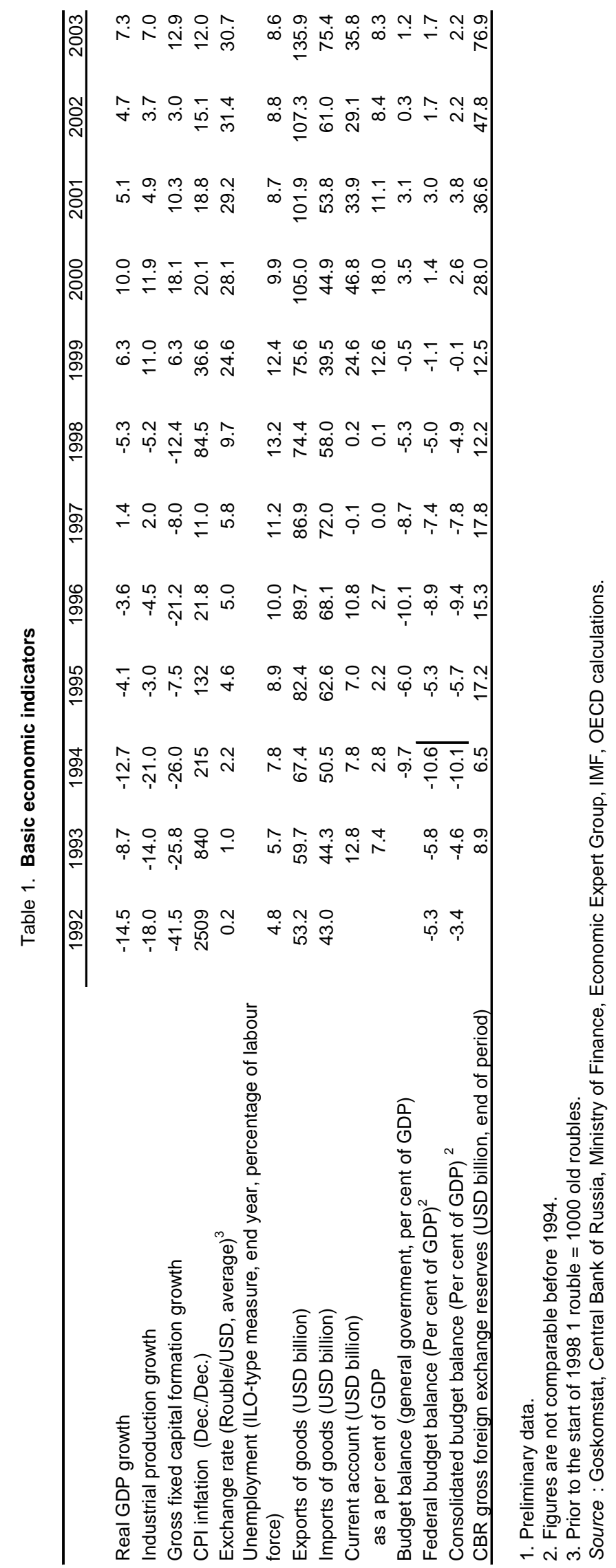




\section{ECO/WKP(2005)17}

\section{The initial reform package was followed by several years of high inflation and falling output}

The immediate results of the initial reform package were a spike in inflation and a large drop in GDP in 1992. What was unexpected, however, was that the output fall carried on far longer than expected. With the exception of a weak pick-up in 1997, the economy continued to contract until 1999. Inflation fell sharply after the initial shock, as had been anticipated, but the authorities succumbed to pressure for looser policies in mid-1992 and inflation surged again. The initial reform package of 1992 might have produced better results sooner had it been followed quickly by a range of other structural reforms needed to create the necessary framework for a market economy. That this did not occur was above all due to the failure to sustain the macroeconomic discipline needed to achieve stabilisation quickly. The reformers had believed that, after the initial freeing of prices, tight fiscal and monetary policies would bring about macroeconomic stability by late 1992 , setting the stage for an output recovery. In the event, it took four years to reduce inflation to double digits. The process of structural reform in many spheres simply stalled, while the government concentrated its energies on stabilisation. In any case, many needed structural measures were opposed by powerful vested interests, ${ }^{8}$ and the weakness of state institutions meant that the federal authorities simply lacked the administrative capacity to implement many structural reforms. Nevertheless, the initial reform push of 1992 succeeded in laying the foundations for a market economy.

The price liberalisation of early 1992 led not only to a large relative adjustment of prices, but also to a sharp increase in the general price level. This initial jump in the price level was expected. It was chiefly a product of the 'monetary overhang' that had developed in the late Soviet period as a result of money wages rising far faster than productivity. ${ }^{9}$ Households and firms at the end of 1991 were holding more roubles than they wished, simply because there was nothing to buy with them. ${ }^{10}$ When prices were freed, this mass of excess roubles drove prices up rapidly. Monthly inflation reached 245 per cent in January 1992. This jump was a one-off adjustment, and monthly inflation declined rapidly to around 10 per cent in the summer. However, this progress proved to be short-lived, as monetisation of budget deficits and largescale financing of the enterprise sector via central bank money creation continued. Inflation rose significantly in the second half of 1992 and stayed very high throughout 1993. The challenge of disinflation was greatly complicated by the maintenance of the rouble zone: the rouble remained the national currency of most former Soviet states in 1992-93, but no satisfactory arrangements for managing it were ever agreed. ${ }^{11}$ Instead, participating central banks abused their ability to create quasi-money, mainly to finance ailing enterprises in their respective countries. Each member state thus reaped the benefits of any additional quasi-money it created, while the ensuing additional inflation was shared across the zone. ${ }^{12}$ There were thus strong incentives for monetary creation. The Central Bank of Russian (CBR) lacked any effective mechanism to prevent such behaviour and was itself heavily engaged in extending soft credits to the Russian enterprise sector. After the break-up of the rouble zone and with the CBR focusing more on limiting growth of monetary aggregates, inflation started to decline from end-1993.

8. In many cases, these interests were precisely those which had gained from the first wave of reforms: incomplete early reforms created winners who resisted further reform efforts. For a detailed analysis, see Hellman (1998).

9. This overhang had begun to develop by about the 1960 s but grew extremely rapidly in the late 1980 s. Wages jumped by around one-third during 1987-91, while output per worker actually declined.

10. In an economy with free prices, this excess rouble liquidity would have resulted in inflation. In the Soviet context, repressed inflationary pressures expressed themselves in chronic shortages, rationing and queues on the one hand, and the accumulation of excess rouble liquidity on the other.

11. It is not clear that any effective regime for governing the rouble zone could have been negotiated, given the political situation at the time.

12. In essence, the rouble zone developed into a classic example of a 'common pool problem'. 
On the official data, real GDP fell by around 32 per cent during 1992-94, continuing the sharp contraction of the previous two years. Moreover, recorded output continued to decline through 1995 and 1996. The initial output drop must to a large degree be seen as the result of the dramatic changes that resulted from the attempt to transform a command into a market economy. Unsurprisingly, 1992 saw the largest drop in GDP - of around 15 per cent. From a demand-side perspective, a large part of the drop was explained by a sharp fall in private consumption that was connected to the uncertainties created by price and other reforms, as well as diminishing real purchasing power. On the supply side, a major reason for the contraction was the attempt to impose hard budget constraints on the enterprise sector for the first time. Yet while the continuation of the downturn in 1993-94 was to a significant degree part of an unavoidable transition shock, there were also other factors at work. High and volatile inflation had a significant negative impact throughout 1993-94, while the gradual break-up of the rouble zone, which did at least allow the CBR to focus on reducing inflation, contributed to further contraction in trade among the former Soviet republics.

While the fall in output was generalised across the economy, there were nonetheless very significant differences between sectors. Resource-based industries, which responded to collapsing domestic demand by increasing exports, held up relatively well, as did the service sector. Domestically oriented industrial sectors, by contrast, fared particularly badly. The low level of international competitiveness of these sectors meant that they could not export their output in order to offset the effects of shrinking domestic demand.

\section{Box 1. Reported GDP declines and socio-economic realities}

While there is no doubt that the initial transition recession was traumatic for Russia, there is considerable debate about just how severe it was and about whether output has yet recovered to its pre-transition peak. Official Russian data show real GDP falling by almost half from 1990 to 1998, with the post-crisis recovery bringing it to just over 80 per cent of its pre-transition level in 2003. In reality, the total output fall was almost certainly smaller than these numbers suggest. ${ }^{1}$ Under the Soviet system, enterprises had strong incentives to over-report their production. Moreover, pre1992 prices had little meaning. Relative prices in the manufacturing and consumer good sectors - compared to prices for natural resources and basic commodities - were generally far too high, so their share in aggregate output was significantly overstated. To the extent that the size of those sectors suffering the sharpest decline was overstated at the outset, so was the subsequent output collapse. Even so, Gavrilenkov and Koen (1994) estimate that real output fell by almost one-third during 1989-94. Much of the output collapse consisted of an end to production of goods that were of questionable value, and for which there was little, if any, demand. This point is highlighted by the fact that roughly 15 per cent of 1991 output proved impossible to sell - even in an environment characterised by widespread shortages and a monetary overhang - and was basically produced for stocks.

Since much of the 'lost' output had contributed little to the welfare of the population in any case, the fall in living standards during the transition - while substantial - was far smaller than the decline in production. This is reflected in both the official statistics (which, critics argue, tend in any case to underestimate incomes and consumption) and survey data on household consumption. Working on the basis of the official data, Gavrilenkov and Yasin (2005) find that private consumption never fell below $90 \%$ of its pre-reform (1991) level and that it has exceeded that level since 2000. Nevertheless, the available data from virtually all sources confirm that the transition has been extremely difficult for most households. Living standards for most Russians fell in the 1990s, and poverty increased dramatically (though it has been falling in recent years), while the health system and other social services deteriorated considerably and remain in dire need of both resources and reform. Indicators of basic human welfare, such as life expectancy, which had begun falling during the Soviet period, have continued to worsen. The incidence of tuberculosis and other povertyrelated diseases has risen dramatically. While there has been a marked rise in incomes and levels of consumption since 1999, with the largest increases in consumption coming among the least well off, health and mortality indicators have yet to improve much.

1. See OECD (1995:8-13) for a detailed discussion of the issue. 


\section{An exchange-rate-based stabilisation strategy reduced inflation but at a very high price}

After the roller coaster stabilisation efforts of 1992-94, the authorities in 1995 opted for an exchangerate based strategy that brought inflation down rapidly. However, this approach brought about a very rapid real appreciation of the exchange rate, which roughly doubled in value over the course of 1995. The toll this took on enterprises' competitiveness probably explains to a large degree why output continued to fall in 1995-96, rather than beginning to recover as the experience of other transition countries would have suggested..$^{13}$ The other major obstacle to recovery was fiscal. The exchange rate-based stabilisation was not accompanied by the fiscal adjustment needed to make it sustainable: the general government deficit was around 6 per cent of GDP in 1995 and rose to 10 per cent in 1996. Indeed, the very success of the exchange-rate strategy allowed the government to postpone fiscal adjustment, as it enabled the government to finance ever larger deficits on financial markets and so to avoid politically costly deficit financing via the printing press. ${ }^{14}$ The rapid growth of short-term domestic debt became increasingly burdensome for the budget, and rising debt service obligations contributed to further increasing budget deficits. The stock of rouble-denominated government debt rose from 4.5 per cent of GDP at the end of 1995 to around 18 per cent of GDP at the end of April 1998. Since the lack of fiscal progress was evident to many observers, there were doubts from the beginning about the sustainability of the exchange rate-based stabilisation. Such doubts kept interest rates higher than they would otherwise have been, thereby aggravating the government's debt problems and prolonging the output contraction.

Politically, fiscal stabilisation would in any case have been extremely difficult, if not impossible, in the circumstances. The rapid real exchange rate appreciation of 1995 had led to sharply rising input costs of labour and energy when measured in international currency terms. As the competitiveness of Russian industry deteriorated, the share of enterprises in 'good or normal' financial condition fell from an already low 35 per cent in early 1995 to 15 per cent at the end of that year. Yet few were bankrupted. Instead, a large part of Russian industry continued to be kept afloat via subsidies. This reflected both the power of industrial managers as a lobby and fear of the social consequences of structural change. Since direct subsidies from the budget and soft credits from the CBR had largely been eliminated by the mid-nineties, subsidisation had increasingly started to take place via unpenalised arrears to the state-controlled gas and electricity monopolies, OAO Gazprom and RAO UES. Enterprises also 'borrowed' increasingly from workers, the state and other suppliers, via wage, tax and payment arrears. ${ }^{15}$ Increasing tax claims in such circumstances led mainly to increases in tax arrears. Yet imposing real financial discipline - Kornai's (1986) hard budget constraints - on the behemoths of former Soviet industry would probably have been politically impossible, given how widespread these problems were. A serious crackdown on non-payments would have risked shutting down a large part of industry overnight.

For a time, three developments served to obscure the seriousness of the situation. First, the debt dynamics were masked by the rapid real appreciation of the rouble. The strengthening rouble ensured that the total debt-to-GDP ratio remained surprisingly constant over $1995-97 .{ }^{16}$ However, as inflation fell and the real exchange rate began to flatten out in 1997-98, the underlying debt dynamics became more

13. In this connection, it is especially significant that some other FSU countries started growing in 1995. Indeed, in 1996, a majority of these countries began to recover, while Russia was still declining.

14. The attractions of deficit spending were limited as long as there was a fairly direct, short-term link between additional spending and inflation. Once it became possible to finance deficits without more or less immediate inflationary consequences, the incentives for deficit spending increased.

15. For details, see Woodruff (1999) and Tompson (1999).

16. At the end of 1997, it stood at an apparently modest 55 per cent (26 per cent foreign, 28.4 per cent domestic). Kharas, Pinto and Ulatov (2001) calculate that in 1996 alone, real exchange-rate appreciation lowered the debt-to-GDP ratio by 8 per cent. 
apparent. Secondly, the economic situation apparently began to improve in 1997. The re-election of the president in 1996 had significantly reduced political uncertainty, and a renewed structural reform drive in early 1997 gave a further boost to confidence. Officially recorded output began to recover, as production started to rise in export-oriented resource sectors. By that time, these sectors were to a large degree privately owned. The major asset-control contests had largely been resolved - partly in the wake of the loans for shares auctions - and the new private owners had begun to increase the efficiency with which their newly won holdings operated. Thirdly, increasing investor confidence, which brought about a shift to net capital inflows for a time, and the foreign exchange inflows generated by resource exports fed a consumption boom in a few regions, which contributed to a small increase in output even in many nonresource based sectors. This gave rise to the widespread impression that Russia had finally made the transition from stabilisation to recovery. A financial boom began in Moscow, despite the fact that Russia's industrial heartlands were still in a very dire state.

\section{Box 2. Comparison of output contraction with other transition countries}

The length and severity of Russia's transition recession stand in marked contrast to the experiences of the 'Visegrad' countries of Central Europe, where output began to recover around two years after the onset of reforms (Figure 1). This difference is partly attributable to greater political instability in the Russian case, which made policy less consistent and less credible, as well as to some avoidable policy errors. In particular, Russia suffered greatly from its failure to bring inflation down in a sustainable way in the first few years of the transition. This meant that the price Russia ultimately paid for stabilisation in terms of lost output was much higher. However, much of the explanation is probably to be found in the initial conditions for reform in Russia. The post-communist transformation was always likely to be more difficult in Russia than in Central Europe. One western study comparing Russia, China, Poland, Hungary and the Czech Republic with respect to three indicators of readiness for the market transition - structural misdevelopment, institutional preparedness for a market economy, and macroeconomic disequilibrium - concluded that Russia was by far the least prepared on all three dimensions. ${ }^{1}$ While the structural distortions of the Soviet economy were similar in kind to those that afflicted other post-communist economies, they were greater in the Soviet case than elsewhere, largely because so much of the Soviet Union's basic industrialisation took place under central planning. Planners did not merely deform an existing industrial base; to a great extent, they created one from scratch, and they did so based on a set of priorities that were sharply at odds with the needs of an internationally integrated Russian market economy. The resulting industrial structure was almost comically inefficient in its use of resources and severely skewed towards defence and heavy industry. Much of the industrial capital stock was thus virtually worthless in any environment dominated by the market rather than the Plan.

1. Ernst et al. (1995:7-13). 


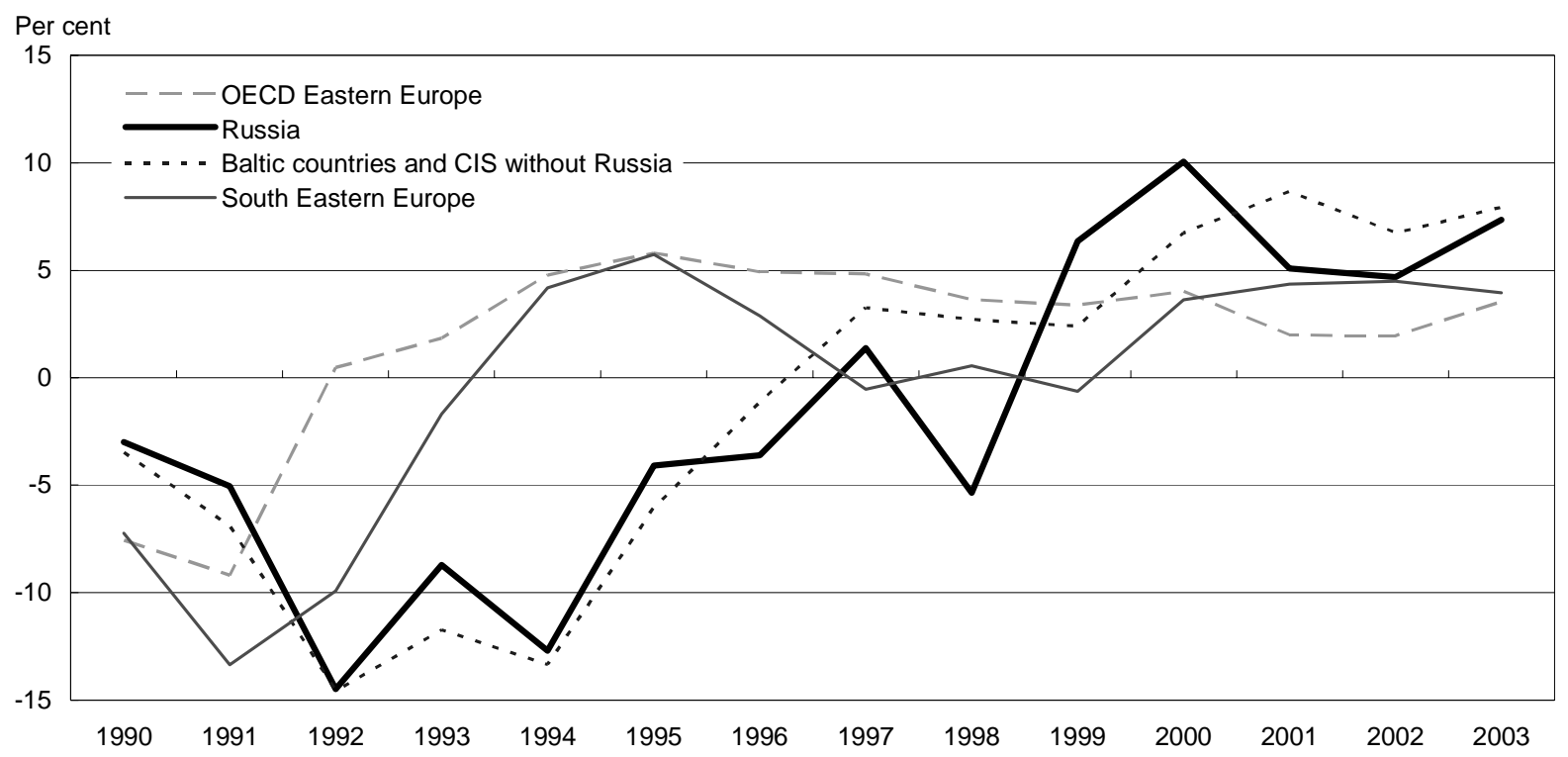

Source : UNECE, World Bank, Eurostat, IMF, Interstate statistical committee of the CIS, Goskomstat and national sources.

\section{The period of the 'rouble corridor' coincided with Russia's most controversial privatisation sales}

While the bulk of Russian industry was at least part-privatised via the voucher scheme during 1992-94, the state kept substantial stakes in what was considered to be the most valuable large enterprises. These were supposed to be sold for cash in a second phase of privatisation. It became clear relatively quickly, however, that there was little demand for those assets at the prices at which the authorities were trying to sell them - partly because of the risks posed by continuing economic and political instability and the prospect of a return to power by the communists, and partly because too many enterprises were effectively controlled by insiders who did not wish to see outside investors (whether foreign or domestic) acquire large stakes. Some of the largest enterprises in which the state had initially kept important stakes were privatised in two stages during 1995-97 through the highly controversial 'loans for shares' auctions. In these auctions, some of Russia's most valuable enterprises (including several major oil companies and the non-ferrous metals giant Norilsk Nickel) were effectively transferred to a handful of well-connected financial-industrial groups for a fraction of their real value. In late 1995, the groups accepted state shares in the companies as collateral for loans extended to the government on the understanding that the lenders could realise the stakes if the loans were not repaid by 1 September $1996 .{ }^{17}$ It was clear all along that the state would not repay the loans; indeed, the 1996 budget contained no provision for this. It was equally clear that the stakes would not be realised in a manner advantageous to the government. The auctions were conducted by the collateral holders themselves, who consistently ensured that the bidding was noncompetitive and that the stakes were purchased by entities they controlled, at prices only slightly above the value of the loans. To take but one example, a 38 per cent stake in Norilsk Nickel was privatised for around USD170.1m, implying a value of just over USD447.6m for a company that at that time was generating an estimated USD1.2-1.5bn per year in export revenues.

17. The lenders were to recoup the funds owed to them by the government and 30 per cent of any privatisation revenues above the amount of the loan, with the state receiving the remaining 70 per cent. 


\section{The Asian crisis and falling commodity prices finally rendered the situation unsustainable}

By early 1998 the economic situation and especially the fixed exchange rate regime ${ }^{18}$ had become unsustainable. The structural reform offensive of early 1997 had quickly stalled, and the fiscal situation remained grave. Both the 1997 consumption boom, with the associated strong growth in imports, and the oil price drop in the aftermath of the Asian crisis, contributed to a strong deterioration in Russia's external balance. When the current account turned negative in mid-1997, it became clear that the exchange rate was not only too high for a significant part of Russian industry, but also - given ingrained capital flight - too high to allow Russia's economy to achieve external balance. Renewed efforts to sort out Russia's messy state finances, bolstered by a new IMF package, brought some short-term relief, but the fundamentals remained unchanged, and capital again began to flow out rapidly. The interest rates that the Russian government had to pay on its short term debt skyrocketed, reaching triple digits in real terms as nervous investors reassessed Russia in the wake of the Asian crisis. ${ }^{19}$ By August 1998, the government was left with no choice but to accept a devaluation of the rouble. The devaluation was accompanied by a forced restructuring of short-term domestic debt - an effective default - and a moratorium on the payment of most private, non-sovereign foreign debt. The devaluation was meant to be limited. However, while a controlled devaluation might have been possible several months earlier, the authorities' attempts to stabilise the rouble around a moderately devalued exchange rate had little credibility in the circumstances, and the rouble soon followed the stock market into free fall. In real terms, it hit bottom against the dollar in January 1999, at about half the pre-crisis level. By then it had fallen 75 per cent against the dollar in nominal terms in five months.

In the immediate aftermath of the financial collapse, the economy virtually came to a standstill. The banking sector had been heavily exposed to rouble-denominated government securities, as well as to the rouble in derivatives markets. It was therefore hit especially hard by the devaluation and default, and many private banks stopped operating, causing the payments system to seize up for a time. Inflation accelerated sharply, and many shops and restaurants simply closed up temporarily. While the CBR sought to unblock the payments system (mainly by injecting liquidity into Sberbank and some other systemically important and/or politically well connected banks) and to rescue the banking system, the government was virtually paralysed for several weeks, until a new cabinet could be formed. In the months that followed, however, the new government executed a massive fiscal adjustment. This adjustment was largely automatic: the government simply refrained from indexing expenditure commitments to reflect surging inflation, while nominal revenues rose rapidly. Politically, such an adjustment was probably possible only because the government really had very little choice in the matter. Substantial borrowing was virtually impossible following the default, and massive budget financing via the printing press would have led rapidly to hyperinflation. While the fiscal adjustment was crucial in stabilising the situation, the sharp fall in real wages after the devaluation, together with a large cut in real social spending resulted in a substantial drop in real household incomes, and poverty increased significantly. Imports also fell sharply as the prices of imported goods quadrupled in rouble terms, so the current account was soon showing a large surplus.

18 From mid-1995 until the end of 1997, Russia followed a crawling peg regime which allowed the rouble to fluctuate inside a narrow, very slowly depreciating band. The authorities abandoned the moving corridor in January 1998, when the fluctuation band was widened to 15 per cent but the central rate was to be fixed for three years at $\mathrm{Rb} 6.2 / \$$.

19. Yields on several short-term Treasury (GKO) issues during the late spring and early summer exceeded 100 per cent, rising to $130-150$ per cent for some series in early July, even though inflation was in single digits. 


\section{The post-crisis recovery began sooner and has lasted longer than most observers expected}

Despite widespread pessimism about Russia's prospects after the crisis, the economy started to recover fairly rapidly. Industrial production began to recover in October, ${ }^{20}$ and by early spring 1999, it had already surpassed the pre-crisis peaks of 1997 . While growth was very broadly based, the recovery was initially strongest in those sectors that had been doing worst before the crisis - domestically oriented nonresource sectors. This dramatic turnaround resulted mainly from the dramatic fall in wages and energy prices, in both real roubles and foreign currency terms, following the devaluation. This large initial decline in input costs allowed a significant share of Russian industry to become competitive and profitable again, while the sharp rise in the rouble prices of imported goods facilitated import substitution on a large scale. The improvement in the economic situation in the 'real sector' was also reflected in steadily declining levels of barter, arrears and non-payments as the economy became re-monetised. The early post-crisis years also saw a wave of sometimes very aggressive ownership consolidation, as though who had weathered the crisis sought to acquire assets cheaply, while exploiting the general confusion in the aftermath of the crisis to default with impunity on their more vulnerable creditors or to squeeze out minority share holders, via share dilutions or simply asset transfers from company to company. Some of today's leading Russian champions of good corporate governance were among the most aggressive in employing the above-mentioned schemes after the crisis. Russian companies also became adept at exploiting the weaknesses of the 1998 bankruptcy law in order to execute hostile corporate takeovers on the cheap, a practice its most expert practitioners developed into an art form. ${ }^{21}$ Many of the large financial groups were also extremely adept at 'restructuring' failed banks in such a way as to shift as much of the value as possible into other vehicles, leaving the state and other creditors empty-handed. ${ }^{22}$

While the devaluation kick-started the economy, a low exchange rate by itself was not the only reason for the post-crisis recovery. In 1994, much the same combination of factors - a weak rouble, cheap domestic energy prices and relatively high export prices for oil ${ }^{23}$ - had failed to prevent a 12 per cent drop in GDP and a fall of more than 20 per cent in industrial production. By 1999, however, liberalisation and privatisation, controversial and incomplete though they were, had facilitated the emergence of an economic system in which private enterprises could and did respond to the opportunity provided by the devaluation. The economy's response to the devaluation and to the subsequent recovery in oil prices was in no small measure a product of the structural changes wrought during the 1990s. In this respect it is important to note that the economy began to grow strongly before oil prices started to recover. Improving terms of trade were undoubtedly helpful later on, but the initial post-crisis recovery was not dependent on, let alone driven by, oil-price increases.

When comparing the Russian crisis of 1998 with similar crises elsewhere two features stand out. The recovery in Russia started unusually quickly after the crash, and it has proved unusually robust. The explanation to the first question is straightforward. The Russian banking system prior to the crisis was not performing the role of a normal banking system (transforming savings into loans), but was mainly playing

20. Industrial production, adjusted for both seasonal factors and workdays, rose by 5 per cent in October relative to September and a further 2.2 per cent in November relative to October. Seasonal adjustment of Russian data is notoriously difficult and such data should always be interpreted with caution. However, the fact that the growth continued on an upward path suggests that these numbers constituted neither a statistical aberration nor a 'dead-cat bounce'.

21. See Lambert-Mogiliansky, Sonin and Zhuravskaya (2000) for details. To some extent, the use of bankruptcy as a takeover mechanism reflected the absence of a well functioning market in corporate control, which would have enabled acquisitions to be executed in a more 'normal' fashion.

22. See Tompson (2000) on the use of 'bridge banks' to escape creditor demands during 1998-2000.

23. Oil prices in 1994 were close to the levels of 1999 in real terms. 
stock markets and investing in government securities. Therefore, the collapse of the banking system did not lead to any noticeable credit crunch in the real sector. Ultimately, the banking crisis had remarkably little impact on economic activity. The reasons for the length and strength of the recovery are less obvious. The - necessarily temporary - boost to economic activity resulting from an unsustainably low real exchange rate and artificially low internal energy prices in 1999/2000 was largely exhausted by 2001, as wages, energy prices and the real exchange rate had all increased significantly. It was in 2001 that the oil sector really took over as the main engine of growth. During 2001-03, Russian oil companies accounted for almost one quarter of GDP growth directly. ${ }^{24}$ Strongly increasing oil exports also drove the expansion in export volumes that allowed a consumption boom to unfold and to be sustained throughout the period without putting the external balance at risk.

\section{High prices and apparent security of property rights contributed to an oil-sector boom}

Although a number of developments in late 2003 and 2004 raised new concerns about the security of property rights, the perception that property rights had become sufficiently secure was one of the factors contributing to the recovery of investment in 2000-01, particularly in the oil sector. ${ }^{25}$ Strikingly, in 2000 the growth of oil-sector investment was led by companies controlled by the state or by oil industry insiders. By contrast, oil companies owned by major financial groups (whose property rights were perceived as less secure) were investing only marginally more than in 1998. In 2001, however, as perceptions of the security of property rights further improved, the latter group of companies began rapidly increasing investment, soon reaching levels comparable with the former group. This investment led to a sharp increase in oil production and exports in subsequent years (Figure 2). Output growth, however, was uneven. From 1998 to 2003, the large insider- and financial group-controlled companies increased output by roughly 45 per cent and 90 per cent respectively, while state-controlled companies increased output only marginally.

Figure 2. Oil sector compagnies : relative performance

Growth 2001-03 inclusive

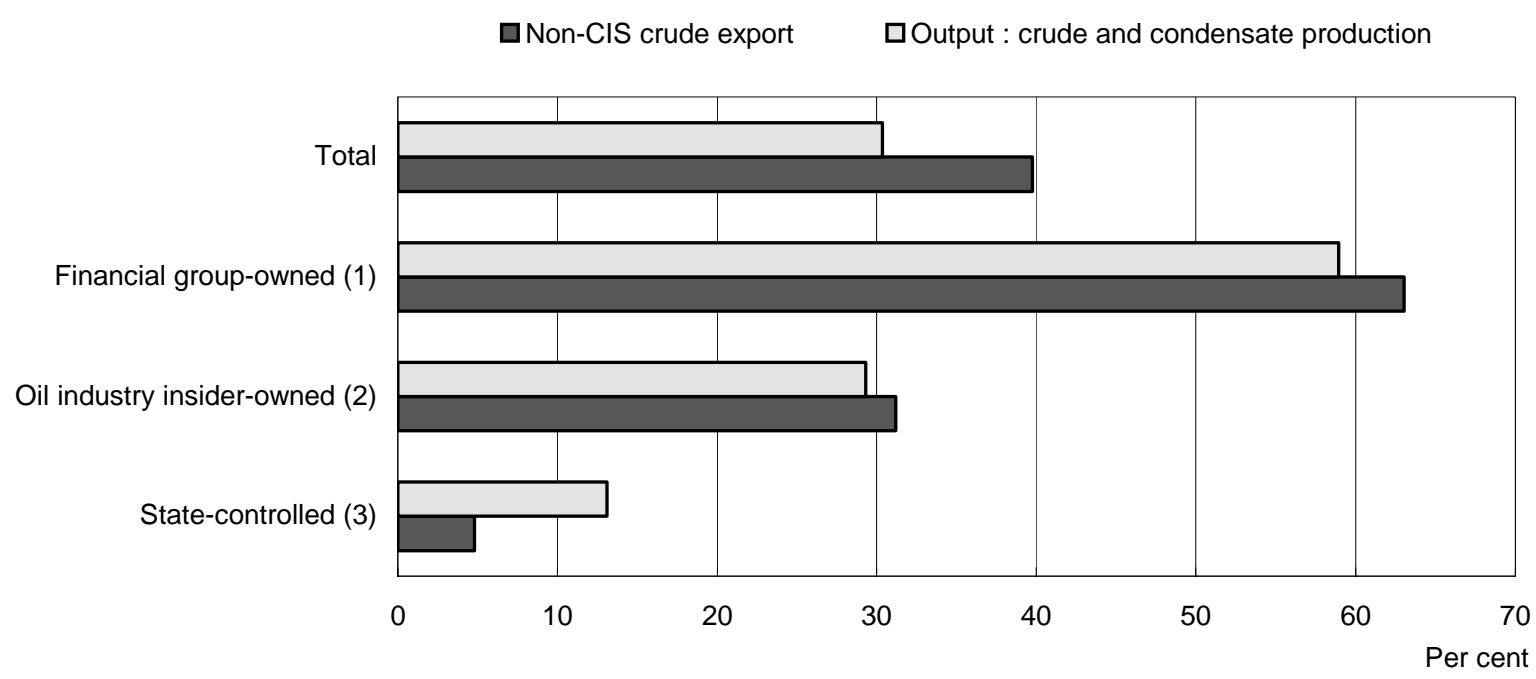

1. Sibneft, TNK, YUKOS.

2. LUKOIL, Surgutneftegaz.

3. Bashneft, Rosneft, Tatneft.

Source: Ministry of Energy, InfoTEK, Rennaissance Capital estimates, RIANTEC, OECD calculations.

24. See Ahrend (2004a).

25. Clearly, high oil prices were another major factor. 
Since the state-owned companies barely grew, this means that Russia's privately owned oil companies directly accounted for somewhere between one-fifth and one quarter of GDP growth (Figure 2). Taking into account the knock-on effects from oil-sector procurement and wages on domestic demand, the actual contribution of the private oil companies to economic growth was probably greater still. It is unlikely that Russia would have been able to grow at anything like the rates it has experienced in recent years had the private oil companies not raised investment, output and exports very rapidly. Moreover, the examples of the state-controlled oil companies and of other important state-controlled companies, especially in the gas and banking sector, would appear to suggest that Russia's leading private oil companies would not have achieved the growth performance of the last few years if they had remained under state control.

\section{Prudent fiscal policies helped to sustain the recovery...}

The government's single most important contribution to the expansion after 1998 was the adoption of a prudent fiscal stance - in sharp contrast to the pre-crisis period. The fiscal adjustment following the crisis was radical indeed: general government expenditures (including all levels of government and social funds) are now about 10 percentage points of GDP lower than before the crisis, while revenues relative to GDP have remained at roughly their pre-crisis levels. ${ }^{26}$ The federal budgets for 2000-04 were drafted to aim for surpluses based on conservative oil price assumptions. This approach not only delivered sizeable surpluses but also a budget that was balanced over the oil-price cycle. To be sure, fiscal responsibility was facilitated by growing revenues due to favourable terms of trade and strong growth. However, the government largely resisted the temptation to spend this windfall, instead using a significant part of it to repay debt and accumulate reserves in a stabilisation fund. The government also took advantage of the favourable fiscal situation to implement a comprehensive reform of the tax system, which would have been far more difficult under other circumstances. In addition, the authorities adopted a number of institutional reforms, including an overhaul of the budget code and the creation of a federal treasury, which improved both the fiscal policy process and the management of public expenditure.

\section{...while monetary policy has struggled to balance inflation and exchange-rate concerns}

Monetary policy in the years after the crisis was dominated by the pursuit of conflicting policy goals, and has de facto been very loose. The Central Bank of Russia (CBR) followed a policy aimed at gradually reducing inflation while limiting the real appreciation of the rouble in order not to endanger the competitiveness of Russian industry. Given large current account surpluses and decreasing net capital outflows, this determination to prevent the rouble from appreciating too rapidly increasingly compelled the CBR to intervene on the foreign exchange markets via large-scale foreign currency purchases. However, in the absence of efficient large-scale sterilisation tools ${ }^{27}$ the accumulation of reserves has led to very strong monetary expansion, which has increasingly conflicted with achieving disinflation.

26. In fact, cash revenues (and thus effective revenues) are substantially higher than they were before the crisis. Pre-crisis federal revenues amounting to 3.6-3.7 per cent of GDP and regional revenues of the order of roughly 6 per cent of GDP were non-cash revenues, consisting of bartered goods, offsets, bills of exchange and other money surrogates. Since the recorded value of these non-cash payments was often substantially greater than their real value, the shift to cash collections means that effective revenues have increased relative to GDP, even if nominal revenues have declined.

27. Large-scale, longer-term monetary sterilisation was until recently impossible, as the CBR was unable to issue its own debt until late 2004. While the statute providing for the issue of CBR bonds was adopted in the 1990s, it was long ineffective, because the corresponding regulation was never issued by the nowabolished securities commission. As a substitute, the CBR used government bonds from its portfolio in reverse repo operations, mainly for short-term sterilisation purposes. The question of short-term sterilisation became especially prominent in 2003, with a sharp increase in speculative short-term capital flows into and out of Russia. 


\section{Russian industry has raised productivity rapidly since the crisis}

Recent years have seen increasing cost pressure on Russian industrial enterprises: the exchange rate has appreciated steadily in real terms since early 2000 and wages have risen rapidly, while energy and transport tariffs, frozen for some time after the crisis, have been rising at well above the rate of inflation since 2000. So far, much of Russian industry seems to have done relatively well in maintaining competitiveness despite these pressures. While industrial production growth slowed in 2001-02, it recovered to around 6-7 per cent in 2003-04. The main reason for this resilience - apart from the dominant role of the oil sector - appears to be significant labour productivity increases in a large majority of sectors. Average industrial labour productivity has been increasing strongly and steadily since 1997 (with the exception of 1998), and the average increase between 1997 and 2003 was around 8 per cent. The performances of different sectors have varied widely, but there have been improvements in almost all of them. The few inglorious exceptions (Figure 3) turn out to be sectors in which there is still significant direct state control over enterprises or extensive state interference in economic activity. The productivity performance of the grain-processing and bread sectors, as well as oil (before 1999) and electricity (until 2002), is uninspiring. The gas industry is not so much at the bottom of the league as in a league of its own.

Figure 3. Labour productivity : changes in the $\mathbf{3 0}$ most important industrial sectors

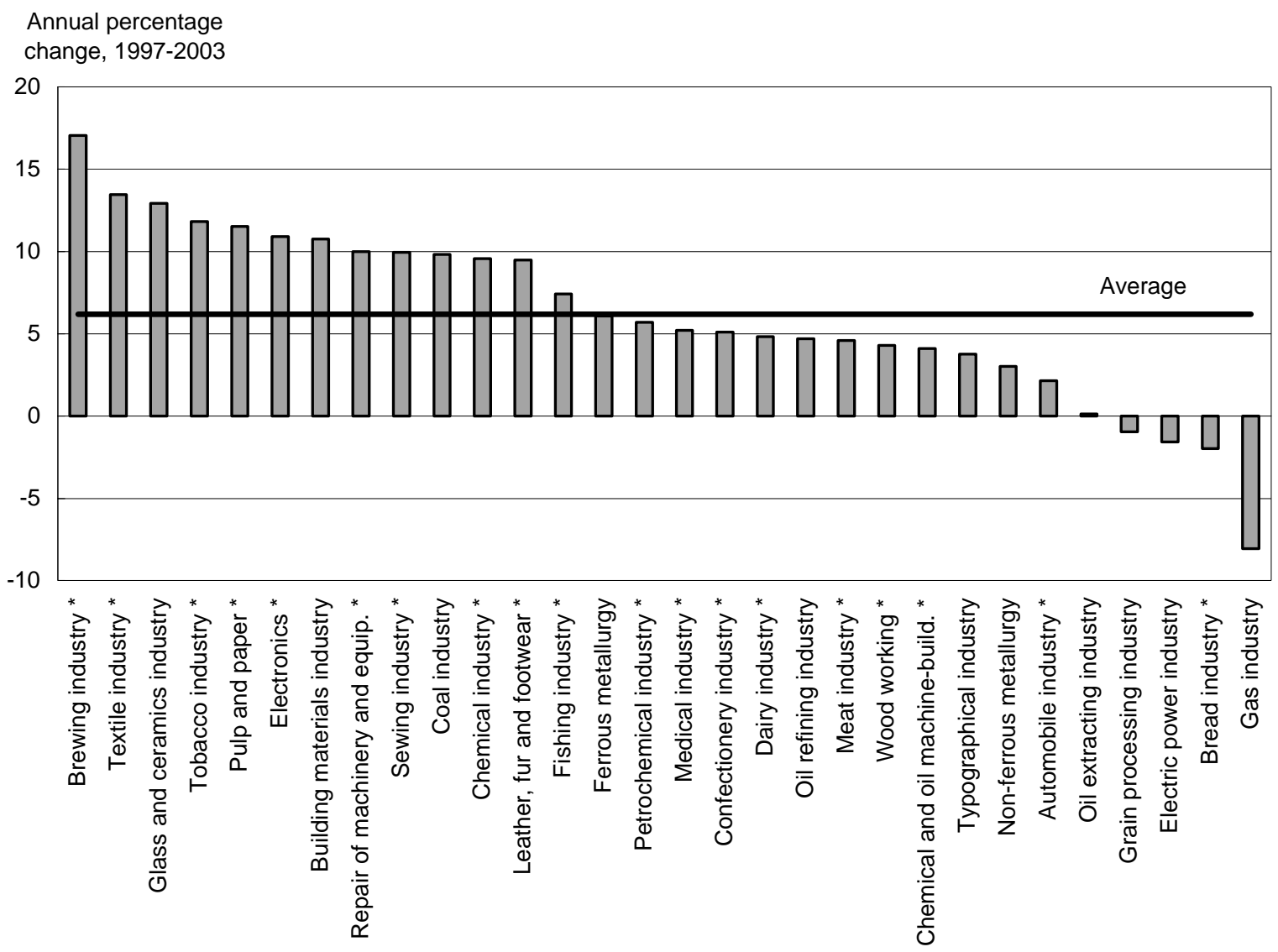

* Data on labour productivity for 1997-2002.

Source: Russian Federal Service for State Statistics and OECD calculations. 
There are indications that there has been a shift to more active restructuring in recent years (Figure 4). While there were even some productivity increases in the period to 1998, they mainly resulted from passive restructuring in pursuit of short-term survival. Enterprises tried to reduce employment as output fell. Then, during 1999-2001, there was what may best be described as a 'recovery'. Productivity increased, but in aggregate this was mainly a by-product of increasing production. There were, of course, enterprises and sectors that restructured very deeply during this period, but it appears that many contented themselves with increasing output, and in aggregate there were no further reductions in industrial employment. It was in 2002, when it became clear that the 'easy' gains from the devaluation had been exhausted, that large numbers of enterprises finally began restructuring with a view to improving productivity. In 2002-04, industrial output grew relatively strongly while industrial employment fell. Thus, despite rapidly rising wages, unit labour costs (ULCs) in industry in 2003 remained about 25 per cent below the levels of 1997, although wages were significantly higher. The major exception to this trend was, again, the gas sector, where ULCs were about 107 per cent above pre-crisis levels.

Figure 4. The composition of industrial productivity growth

Annual percentage change

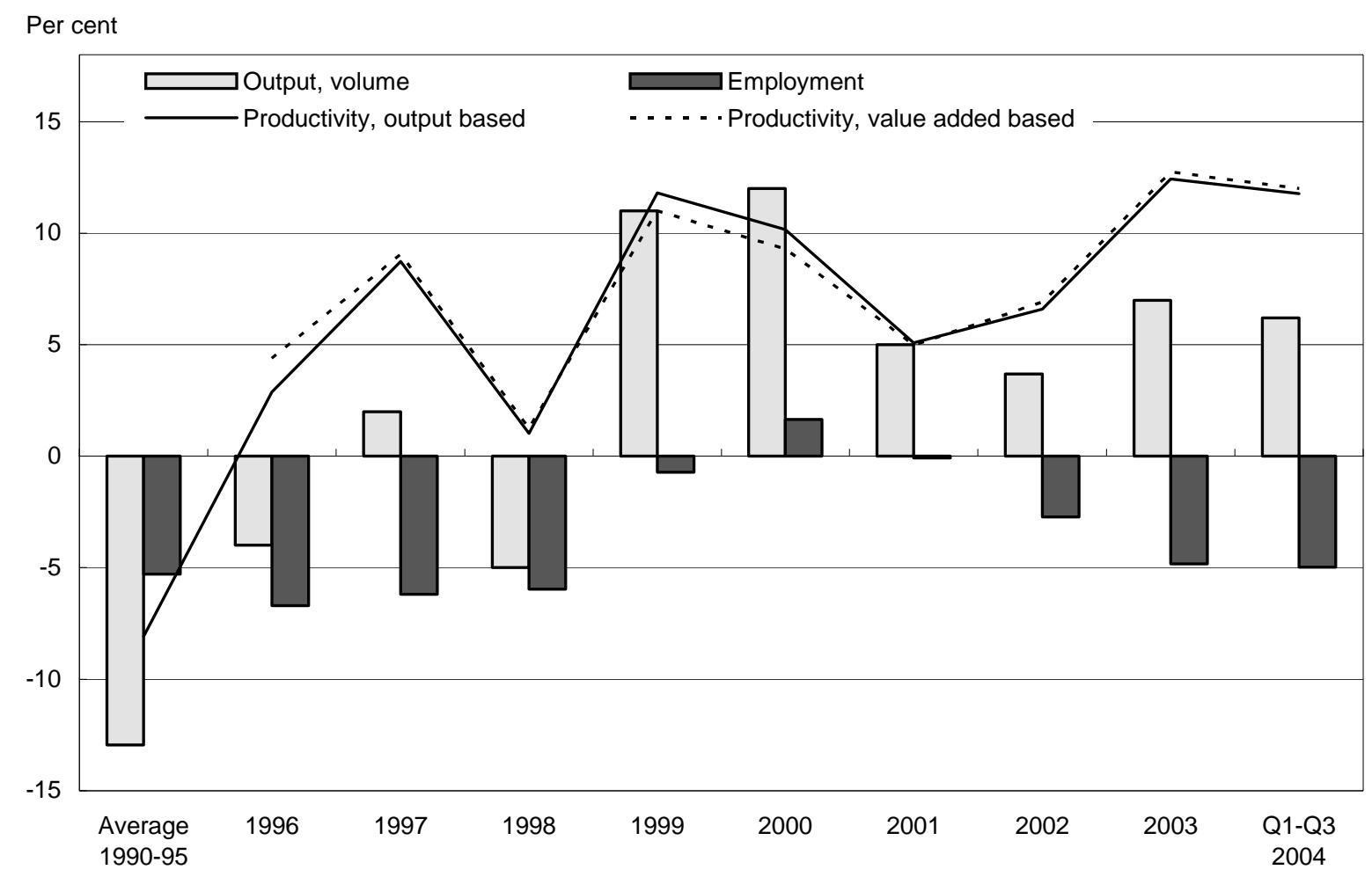

Source: Russian Federal Service for State Statistics and OECD calculations. 


\section{The post-crisis expansion has coincided with a period of renewed structural reform}

The 1998 financial collapse was the product of unsustainable macroeconomic imbalances that were to some degree the result of a lack of progress with respect to structural reforms after about 1993. The fragile macroeconomic stabilisation of 1995-98 was never underpinned by the micro-level structural changes needed to render it sustainable without massive infusions of external financial support. In particular, the authorities proved unwilling to impose hard budget constraints on large firms, which continued to receive substantial implicit and explicit subsidies. ${ }^{28}$ Ultimately, macroeconomic stability cannot last where firms are not subject to hard budget constraints. To say this is not to minimise the significance of the external shocks that hit Russia as the Asian crisis spread in 1997-98 or to downplay the importance of fiscal weakness. The point is rather that the lack of structural reform increased Russia's vulnerability to the Asian typhoon. Structural reform failures also cost the state budget dearly and thus contributed to a rapid, and ultimately unsustainable, growth of state debt. After the crisis, therefore, the government renewed its efforts to press ahead with long-delayed structural reforms in spheres ranging from taxation to electricity to banking (see Box 3).

\section{Box 3. Structural reform progress since the crisis}

In legislative terms, at least, the period since 1999 has witnessed considerable progress on structural reform. ${ }^{1}$ Perhaps the first important post-crisis achievement was the passage of part 2 of the new Tax Code in 2000, albeit without the chapters on the profit tax and resource taxes, which were adopted the following year. Land reform, which had been stalled throughout the 1990s, moved forward with unfreezing of chapter of 17 of the Civil Code, which governs property relations with respect to land, although agricultural land was excluded from its provisions. ${ }^{2}$ This followed by a new land code and a new law on the purchase and sale of agricultural land. The new labour code reached the statute books in 2001, as did a trio of bills aimed at reducing bureaucratic interference in the economy, and the major elements of the government's judicial reform. The basic legislation on pension reform was adopted in December 2001, with additional legislation following in 2002-03. A new law on combating money laundering authorised the creation of a new body for monitoring questionable financial transactions. Though initially criticised by many observers as too weak, the money-laundering law was subsequently strengthened and Russia was in 2002 removed from the FATF's list of states that fail to combat money laundering. The authorities adopted a number of measures to improve the framework for corporate governance in 2001-02, including new laws on bankruptcy and jointstock companies and a corporate governance code, which broadly reflects the OECD Principles of Corporate Governance. The 2002-03 period also saw the adoption of new laws on currency controls (phasing out almost all capital controls); a new law on technical regulation; a new customs code; and the government's electricity reform package. While the pace of legislative activity slowed somewhat in 2004, the government did continue its reform of the tax and budget codes, particularly with respect to fiscal federal relations.

Altogether, this legislative record represents a considerable achievement, particularly in view of the large number of contentious measures passed in 2002-03, when the opposition of entrenched special interests and the approach of parliamentary and presidential elections made the government's task much more difficult. On the whole, the new laws, whatever their imperfections are an undoubted improvement on the legislation they have replaced. In some cases, the new legislation does not replace anything but rather fills gaps in the legal frameworks governing various spheres of activity. Russian commercial law in many spheres is now of very high quality. However, improvements in the quality of legislation have not yet been matched by improvements in the quality of the institutions that implement the law or those that resolve legal disputes and enforce the law. The weakness, inefficiency and, in many cases, corruption of the courts, the law enforcement agencies and of the state administration thus constitute the most important obstacles to realising further progress in improving the framework conditions for business in Russia. Judicial reform itself exemplifies this problem: a major overhaul of the various codes of judicial procedure and of the framework laws governing the judiciary was completed in 2001 , and did indeed result in substantial improvements in the quality of the law itself. However, there has been little evidence to date that the functioning of the courts has really improved much. Similarly, the positive impact of the trio of laws adopted in 2001 to reduce the bureaucratic burden on business has been limited, chiefly because the officials affected by the legislation resisted its effective implementation.

28. For an excellent analysis of the authorities' attempts to pursue stabilisation without imposing hard budget constraints, see Pinto, Drebentsov and Morozov (2000). 
That said, structural reform progress has not by any means been limited to legislation alone. The authorities have since 2000 been engaged in the painful but necessary process of rebalancing domestic and international rail tariffs and of raising the tariffs charged by the country's electricity, natural gas and rail transport monopolies. The implementation of pension reform began in 2003, although it soon encountered difficulties that led to some amendment of the reforms. Finally, two crucial and long-delayed reform processes have begun to move forward since 2001: reform of the power sector and banking reform. Both are meeting serious resistance and are moving less quickly than proponents would like, but the progress of the last three years has been dramatic indeed by comparison with the preceding decade, when both electricity and banking reform were repeatedly postponed. Moreover, despite numerous delays and political compromises, the pace of reform in both sectors since the beginning of 2002 compares relatively favourably with the speed at which similar reforms have been executed in other emerging market economies. That said, developments since early 2004 have given cause for concern. To their credit, the authorities managed to press ahead with a number of structural reforms through the 2003-04 electoral cycle, but the post-election period, which many observers had expected to see a sharp acceleration of structural reform, has in fact witnessed a marked slowdown in progress with respect to a number of important structural reforms and, in some cases, movement away from the programme of liberal reforms to which the government had been committed since 2000 .

1. For details, see OECD (2004a), Annex 1.A2.

2. When the code was adopted in 1995, the suspension of this highly controversial chapter 17 had been the price the government paid to get it through a Duma dominated by opponents of land reform.

Strikingly, while reform in many other areas accelerated after the crisis, the pace of privatisation slowed markedly. This was partly because the most attractive assets had been substantially privatised by then. This made further sales even more difficult, for two reasons. First, the political struggles over the remaining prime assets were intensified. Secondly, there was little demand for residual state shareholdings in otherwise attractive companies that were already controlled by a private owner or group of owners. At the same time, the state was left with a large number of less attractive assets, which have not been easy to sell. Moreover, the privatisation scandals of 1995-97 followed by the financial crisis of 1998 and the political uncertainties of 1999-2000 all served to slow the process.

The period after 2000 saw some improvements in both investor sentiment and the state's performance in the field of privatisation, but these changes were limited. In principle, major sales should now take place on a transparent, competitive basis, with mechanisms designed to maximise the sale price realised by the state. However, there have been few such sales. Year after year, ambitious privatisation programmes are unveiled but not implemented, and many of the sales that have gone ahead have been extremely controversial. Transparency and competition continue to be limited. In some cases, the authorities have ended up re-writing the terms of privatisation sales in the middle of the process, which has done little to enhance either government credibility or investor confidence. While sale prices are a good deal higher than in the shares-for-loans era, there is still a widespread perception that the winners in major privatisation competitions are usually determined in advance - and that they are already close to the companies they are buying. The most notable exceptions to this rule have involved assets being contested by rival business groupings. Ironically, this means that the most 'successful' privatisation sales in revenue terms are often among the most politicised and controversial. ${ }^{29}$

29. The two most striking examples of this tendency are the Svyazinvest sale of the summer of 1997 and the sale in 2001 of a stake in Kuzbassugol. Though hardly one of the most promising industrial concerns in Russia, the sale of 80 per cent of Kuzbassugol fetched a price that valued it more highly than some of the resource giants sold off in the shares-for-loans scam of the mid-1990s. The lesson seems to be that rivalry among Russia's commercial 'oligarchs' contributes more to the success of privatisation than the competence of the privatisation authorities themselves. However, such rivalries mean that the most competitive - and lucrative - privatisations have sometimes given rise to the biggest scandals. The political fallout from the Svyazinvest scandal hardly enhanced the incentives for the authorities to conduct fair, transparent sales: the Svyazinvest deal provoked a fierce battle among Russia's business clans that ultimately led to the resignation of several senior officials. 


\section{The impact of structural reforms to date}

The section that follows offers an assessment of the contribution of economic reforms to Russian economic performance. It is, of course, notoriously difficult to quantify the contribution of this or that reform on economic outcomes. Many of the judgements that follow are therefore somewhat tentative. However, the evidence does suggest that together with responsible macroeconomic management, structural reforms in Russia have laid the basis for the robust growth of recent years. There remains, of course, much to be done, and the main challenges for Russia today are outlined in later sections. First, however, it is important to assess in detail the contribution of structural reform to Russian economic performance so far.

\section{More than a decade of transformation has transformed the structure of ownership...}

Perhaps the most dramatic structural change of the post-Soviet period - and certainly the most striking at first glance - has been the rapid shift to an economy based on private property. By 2002, the private share of total employment had risen to 63 per cent. The private sector now accounts for an estimated 70 per cent of GDP ${ }^{30}$ including about two-thirds of industrial production. The official data for 2002 show enterprises in private Russian and foreign ownership accounting for 66.2 per cent of industrial production, with wholly state-owned and municipal enterprises accounting for just 9.5 per cent. The nature of the state's continuing role as a property owner is reflected in the 24.3 per cent share produced by enterprises with mixed state-private ownership.

The structure of private property that has emerged since 1992 is dominated by a relatively small number of large industrial groups, most of which are tightly controlled by a small number of core shareholders and organised around some commodity exporting business. Recent research suggests that the ten largest industrial groups, together with the state-controlled national gas and electricity companies, account for roughly half of Russian industrial output. ${ }^{31}$ These groupings have in recent years tended to pursue strategies of vertical integration. Such strategies are in part a rational response to the potential uncertainties and risks connected with enforcing contracts with third parties in the Russian legal environment. Moreover, industry consolidation has yielded benefits in terms of enterprise performance. In contrast to the remaining large state-owned companies, the privately held industrial groups have generally restructured the businesses they owned or acquired in recent years and most of them are fairly well managed. The productivity of many private industrial groups' enterprises has been increasing briskly, and in general they have outpaced industry as a whole in terms of restructuring. ${ }^{32}$ While expanding into new sectors, most of these groupings remain heavily focused on their core businesses. Expansion tends to be into sectors closely related to their core businesses. ${ }^{33}$ The fact that most of the groupings are based on commodity export businesses operating in competitive global markets means that consolidation offers them economies of scale and makes it easier for them to compete alongside large non-Russian players in the same sectors.

Nevertheless, this concentration of ownership may pose issues for competition policy. The groupings' growth appears to be driven largely by a desire to monopolise entire sectors, or even groups of related sectors. This is especially true of the most recent wave of industrial consolidation. Whereas in the 1990s, banks and cash-rich resource companies simply bought up whatever they could as fast as they could, M\&A

30. EBRD (2003:186). This is an EBRD estimate; the Russian statistical authorities do not publish data on the private-sector share of GDP.

31. Dynkin (2004).

32. See also Boone and Rodionov (2002).

33. See Dynkin (2004). 
activity since the crisis - and especially since 2000 - has been characterised by a determination to create vertically integrated structures. ${ }^{34}$ Often companies with monopoly or near-monopoly positions in one sector sought to use their market power to extend their reach up- or down-stream into related sectors. This has been a feature of the behaviour of some state-owned companies as well as some of some large private ones. Given the large number of sectors that are dominated by a few large enterprises, securing dominant positions in major sectors is relatively easy to do in Russia.

While such consolidation may threaten to suppress competition in product markets, it is important to understand that many of these markets were not very competitive to begin with - a factor which has itself been a major impetus to pursue vertical integration. The industrial structure inherited from the Soviet Union was characterised by particularly 'long chains of dependence', lacking the 'resilience and flexibility built on redundancy in markets'. ${ }^{35}$ This lack of alternative suppliers and customers left enterprises vulnerable and one response was to seek security by taking direct control of up- and down-stream activities. The impetus for metals producers to secure control of upstream coal and automobile enterprises, for example, largely reflected the limited options they faced when sourcing their energy supplies or marketing their output. ${ }^{36}$ Many major industrial sectors may thus face a future of monopoly domination or oligopolistic competition, in which the main players may compete with each other - more in the political arena than the commercial - but will be strongly tempted to collude to exclude new entrants or to manipulate prices. In this situation, there will clearly be a need for stronger competition policy, but the extent to which producers are subject to competitive pressures will also depend to a very great extent on the international openness of the economy. This is a major reason why Russia's entry into the World Trade Organisation (WTO) is so important to the success of economic reform: it should entrench the openness of the economy and make it harder for domestic players to suppress competition.

\section{... as well as the structure of production, employment and foreign trade}

In addition to changes in ownership, the early 1990s witnessed an important shift in the production structure of the economy, especially within the industrial sector. The output of natural resource-based sectors fell by roughly 40 per cent during 1992-94, while that of other industrial sectors declined by roughly 60 per cent on the official data. The weight of natural resources in the economy increased accordingly. There was also a significant shift from goods production towards the service sector, which had been neglected by Soviet planners. However, this shift was far less dramatic than it appears in the official data. This is because a significant share of value added in export-oriented resource sectors shows up in the official statistics under services (wholesale trade, in particular), as a result of the transfer pricing employed by major resource exporters. Figure 5 shows the structure of the economy as it appears in the official data and a depiction based on an alternative set of weights computed by the World Bank in an effort to correct for transfer pricing. ${ }^{37}$ The services sector now accounts for around 46 per cent of GDP, as

34. As a rule, the groups formed in the mid-1990s set about rationalising their structures, abandoning some activities to concentrate on others.

35. Ericson (1998:622).

36. The coal concern Kuzbassugol provides an excellent case in point. A medium-sized company in a not especially promising sector, it fetched more than $\$ 180 \mathrm{~m}$ when it was privatised in the autumn of 2001 . The price of Kuzbassugol was driven up by the rivalry between steel concerns Severstal and Evrazkholding, each of which feared the consequences of allowing the other to control Kuzbassugol.

37. Here and elsewhere in this chapter, the data on Russia's economic structure and on the contribution of various sectors to growth differ from the official Russian data. The numbers given here are based on the adjusted sectoral weights estimated by the World Bank in an attempt to correct for the distorted picture of Russia's economic structure that results from the widespread use of transfer pricing. For details, see OECD (2004a:28-9) and World Bank (2004). 
against an estimated 36 per cent in 1990, with market services accounting for most of the growth. At the same time, the share of industry has fallen from around 54 per cent to about 41 per cent. The share of rawmaterials-producing sectors in industrial output and exports has risen sharply, while that of processing industries has contracted.

Figure 5. Structure of GDP

A. Official weights GDP 2003, current basic prices

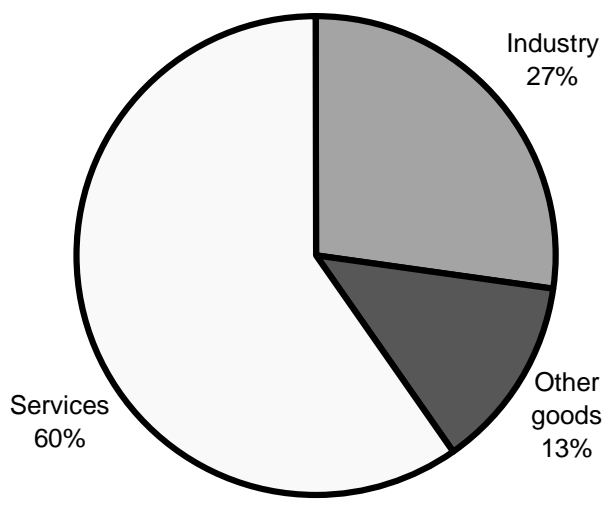

B. Adjusted weights GDP 2003, current basic prices, WB weighted

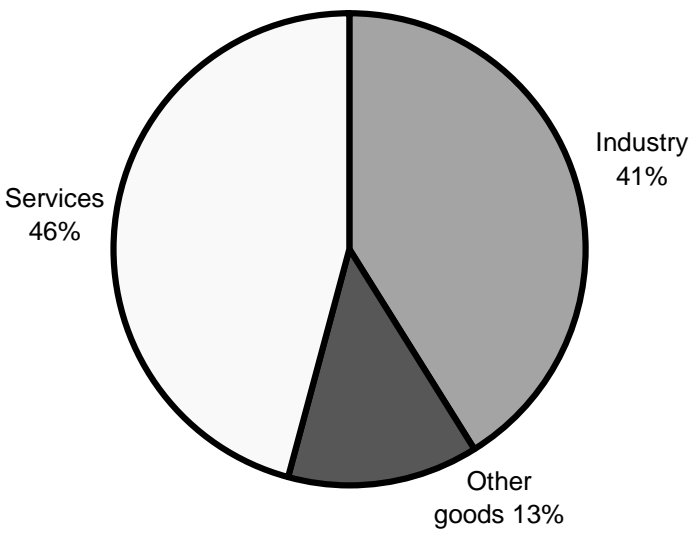

Source : Goskomstat, World Bank and OECD calculations.

Changes in the structure of production were mirrored by changes in the labour market. According to one Russian study, more than 40 per cent of the workforce changed profession during 1991-98, two-thirds of them doing so during 1991-95. ${ }^{38}$ Industry's share in total employment fell by 12 percentage points between 1990 and 2002, from 42.3 per cent to 30.3 per cent. ${ }^{39}$ In fact, the drop in the absolute level of industrial employment was even greater than this figure suggests, since total employment fell by 12.8 per cent over the same period. There were also important relative shifts within industry. Sectors that were not very productive (and often hugely loss-making) reduced employment, sometimes significantly, whereas sectors that were doing comparatively well (i.e. mainly export oriented, natural resource-based sectors) roughly maintained, or sometimes even increased employment. ${ }^{40}$ The service sector's share in total employment rose from 42.1 per cent in 1990 to 55.9 per cent in 2002. Nevertheless, although employment in market services grew faster than any other sector - its share rose from 16.7 to 26.6 per cent over the period - the bulk of service-sector employment is still in non-market services, which accounted for 29.3 per cent of total employment in 2002, up from 25.4 per cent in 1990. Given that the output of nonmarket services sectors fell in absolute terms and relative to GDP over the period, this increase would appear to reflect a lack of restructuring and the desire of some part of the labour force to escape the rigours of the market, rather than the dynamism of this sector.

38. Gimpel'son and Kapelyushnikov (2004).

39. The data in this paragraph are taken from World Bank (2004:51).

40. Employment in the natural gas sector rose dramatically, although there was no corresponding increase in output, which largely stagnated. See Ahrend (2004b) for details. 
Russia's trade structure has also undergone substantial changes, particularly in terms of its geographic orientation. The break-up of the USSR and the subsequent liberalisation of trade were accompanied by a massive re-orientation of trade flows away from the former Soviet Union (FSU) to non-FSU countries. This shift was reinforced by the break-up of the rouble zone, as well as the difficult economic circumstances many of these new states and their enterprises found themselves in. Whereas 26.7 per cent of Russian exports went to other CIS states in 1993, and fully 30.0 per cent of imports originated in other CIS republics, the corresponding figures for 2003 were just 15.7 and 21.0 per cent respectively. ${ }^{41}$ The export and import shares of former communist states in Central and Eastern Europe both fell sharply in the 1990s: the region's share in Russian exports fell from 14.3 to around 10 per cent, while its share of imports fell by almost half, from just over 13 per cent to around 7.3 per cent. The share of exports to, and imports from, OECD countries rose markedly over the same period, particularly the import share.

The fall in trade with other former Soviet states and Eastern Europe was linked to shifts in the commodity structure of Russian trade. On the export side, this reorientation proved especially painful for Russian manufacturers, as their products were generally uncompetitive on western markets. Basic commodities - chiefly hydrocarbons, but also metals, timber, pulp and paper, mineral fertilisers and diamonds - already dominated Russia's export structure at the start of the market transformation, and this reliance on primary products increased over the post-Soviet period, leaving Russia with a very high commodity concentration of exports (Figure 6). The share of machinery and equipment in total exports fell from almost 20 per cent at the end of the Soviet period to under 8 per cent in 2003. This decline would have been even more precipitous had it not been for the recovery in arms exports after the mid-1990s. Moreover, an increasing share of Russia's exports consist of mineral products and semi-finished goods whose production is highly energy intensive and also involves significant environmental externalities; examples include base metals and chemicals, as well as cellulose and paper products. Rising domestic energy prices are reducing the competitiveness of many of these exports, while any serious effort to raise environmental standards could reduce the price competitiveness of many such products. On the import side, the most visible shifts include a sharp increase in the shares of food and consumer goods in the total import bill - while the share of machinery and transportation equipment remains quite large, it now consists largely of consumer electronics and passenger autos rather than investment goods.

41. Data for 1993 are used for the first year of liberalised trade, partly because the 1992 data are incomplete and of poor quality but also because trade was so severely disrupted in the months following the Soviet collapse, that the 1992 figures are clearly a sharp aberration from the trade patterns seen before or since. 


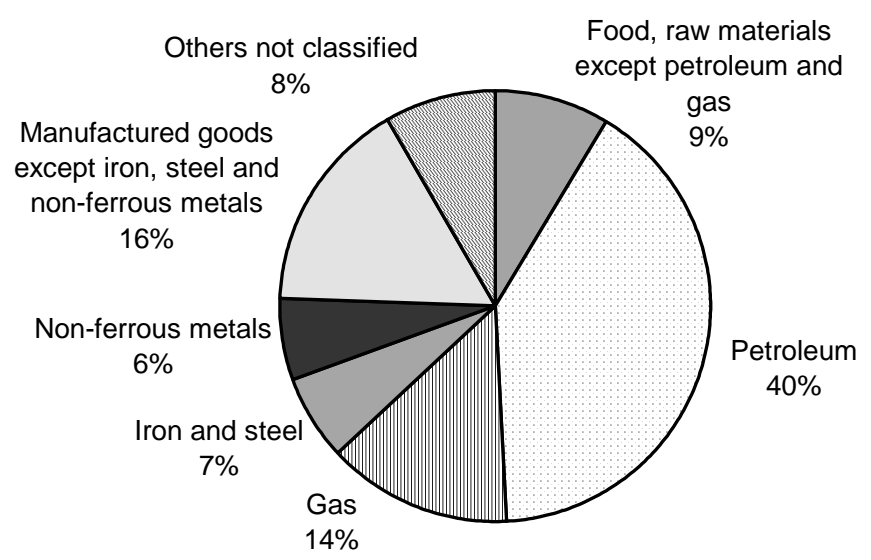

Source: United nations, Commodity Trade Statistics Database (COMTRADE), SITC Rev 3.

\section{Price liberalisation, though painful, has brought significant benefits}

It is difficult to exaggerate the impact of the initial price liberalisation undertaken in 1992. Rapid price liberalisation was intended to ending the chronic shortages resulting from artificially low regulated prices for most goods and services, as well as to absorb the monetary overhang described above. Most important of all, price liberalisation was essential if prices were to begin to perform their 'normal' function of providing information about the interaction of supply and demand, thereby creating new incentives for production and investment. Despite widespread scepticism about the ability of enterprises to respond to price signals, the evidence suggests that they did indeed respond fairly rapidly, adjusting prices and output in response to feedback from the market in the form of price changes. Queues and the shortages that gave rise to them disappeared, while the structure of production and employment began to change rapidly. The subsequent rapid development of the private trade and service sectors, which had been neglected under central planning, owed much to the signals generated by free prices. Price liberalisation thus resulted in a dramatic improvement in the availability of goods and services that had been difficult or impossible to obtain prior to the reforms. However, low purchasing power put strict limits on what was affordable to most of the population and the impact of liberalisation on different social groups varied a great deal. This reflected not only the effects of inflation but also the fact that some individuals and groups had simply been better positioned than others to obtain scarce goods under the old system of administered allocation. This advantage disappeared with the shift to allocation by the market rather than bureaucratic fiat.

Price liberalisation also offered a way to protect the integrity of a still fragile Russian Federation and to help reconstitute Russia as a unified economic space. In late 1991, the centrifugal tendencies that had contributed to the break-up of the Soviet Union also appeared to be threatening Russia. The breakdown of the Soviet system had not replaced administrative allocation with market allocation. Instead, it had devolved administrative power to regional and local governments, which had responded to - and aggravated - the country's worsening shortages by setting up their own trade barriers and taking over the management of their local economies in the pursuit of self-sufficiency. The federal government was no longer able to ensure that the capital was supplied with food and goods, and Russia's economy had begun to fragment. Price liberalisation helped to address this challenge: barter and administrative allocation began to decline and money to matter, creating powerful incentives for agents to circumvent territorial administrative barriers if they could. The growing role of money also enhanced the authority of the federal centre, owing to its control over monetary policy. In August 1992, the government claimed, with some 
justice, that these changes had strengthened the federation vis-à-vis the regions. ${ }^{42}$ This declaration of victory in the struggle to reassert central authority and make Russia a single economic space was undoubtedly premature, but it was not by any means without foundation. The concern with Russia's economic fragmentation forms an important, if often overlooked part of the story of price liberalisation, which helped to open up local product markets and to facilitate the flow of goods and services throughout the country. ${ }^{43}$

The liberalisation process was, to be sure, extremely difficult for enterprises and households, and would have been even if the authorities had managed quickly to stabilise the overall price level. After all, the move from a system in which the allocation of goods owed more to rationing mechanisms than to purchasing power involved both winners and losers in relative terms; moreover, some of those, such as pensioners, who had lost out under the shift from queuing and rationing to price-based allocation were also more affected by continuing high inflation even after the initial adjustment. The 'big bang' nature of the initial liberalisation package has therefore attracted much criticism. However, as noted above, the system of fixed prices had more or less broken down by late 1991, raising questions about the feasibility of a more 'gradualist' approach. Moreover, the big bang of January 1992 was not as sweeping as is sometimes supposed. Many more prices were freed two months later, but the remaining national-level controls on hydrocarbons and other basic commodities had knock-on effects on other markets, and regional authorities were permitted to introduce local controls, which most did. Energy prices, in particular, continued to be regulated, for fear that a rapid convergence between domestic and international energy prices would bankrupt large swathes of industry. ${ }^{44}$ As a result, an estimated 30 per of GDP was still covered by price controls in 1995 (OECD, 1995:27).

\section{Liberalisation of foreign trade and FDI has benefited consumers and increased competition}

Although the initial liberalisation of foreign trade involved some fairly dramatic measures, trade policy was used in a number of spheres to hold down the domestic prices of key industrial inputs once price controls had been removed. In many cases, the differentials between the domestic and international prices for such goods actually increased. Most important among these commodities were oil and gas; they were also the commodities on which such export restrictions (in the form of quotas and taxes) were kept in place the longest. Price regulation, export tariffs and quotas, and formulae for allocating access to export pipelines have all been used to hold down internal prices of these two fuels. As a result, at the beginning of 2002 - a decade after the initial 'big bang' price liberalisation - the domestic price of oil was still under 30 per cent of the world market price of Urals crude and the average domestic wholesale price of natural gas was about 12.5 per cent of the export price. In the early stages of transition, there were also import controls on many commodities, as well as subsidised imports of some necessities. Thus, Russia began the transition with an extraordinarily open import regime but heavily regulated exports. This quickly began to change, however. As the rouble strengthened and protectionist pressures increased, Russia developed an increasingly complex import tariff structure - by the mid-1990s, it included tariff definitions for around 3,500 product categories. This complex and cumbersome system gave rise to much corruption, particularly because officials had the opportunity to misclassify more heavily taxed goods into lower-tariff categories.

The consequences of this continued over-regulation of foreign trade were serious. The fiscal costs of import subsidies and the remaining price controls were one of the major reasons why macroeconomic

42. Izvestiya, 19 August 1992.

43. For one of the few serious analyses of the impact of price liberalisation on centre-periphery relations, see Woodruff (1996).

44. Accustomed to energy prices held at around 10 per cent of world levels and little concerned with costminimisation, Soviet industrial enterprises were fantastically energy-inefficient. 
stabilisation proved so difficult in the early 1990s. Controls on exports and imports also created enormous opportunities for both official corruption and highly profitable arbitrage operations by those in a position to exploit them. The wealth and influence of the officials and entrepreneurs involved in such activity, moreover, tended to strengthen the resistance to further liberalisation. As a result, many of the steps toward further trade liberalisation envisaged in the government's February 1992 policy memorandum were never implemented. It is difficult to escape the conclusion that the liberalisation of exports and the elimination of subsidies and quotas on imports were too slow and too limited - not too rapid.

Nevertheless, it would be a mistake to exaggerate the impact of these shortcomings. On the whole, Russia has benefited from a fairly consistent process of trade liberalisation over the last dozen years or so, a process underpinned in recent years by its determination to enter the WTO. At the same time, policy became more 'normal' during the 1990s, as exports were gradually liberalised while import-competing sectors secured a degree of protection from foreign competition. Russian import tariffs are relatively low by international standards - the simple, unweighted average was around 10.8 per cent in 2002 - and its tariff structure increasingly resembles those of OECD countries. The overly complex tariff structure that had evolved in the 1990s underwent a fundamental overhaul at the end of 2000. At the start of 2001, over 30 per cent of products were classified into just four categories with tariff rates of 5 per cent, 10 per cent, 15 per cent and 20 per cent. Although a few products, including cars, sugar, alcohol and tobacco, continued to be taxed at rates well above 20 per cent, these changes brought the average rate down to 11-12 per cent. Over time, the number of 'peaks' in the tariff schedule has declined; there are relatively few tariffs now above 15 per cent. ${ }^{45}$ These changes do appear to have reduced import misclassification, thereby reducing at least one form of corrupt behaviour in the customs service. Moreover, the simplification of tariff schedules and the legal requirement that tariffs be revised no more than twice a year have made tariff policy more transparent and predictable.

Russia eliminated many formal obstacles to foreign investment in the earliest stages of the market transformation, opening up the economy to foreign investment after a period of 75 years during which it had been almost entirely closed to outside investment. A further push to improve the legislative framework governing foreign investment - and foreign direct investment (FDI) in particular - was undertaken after the 1998 financial crisis. A law on foreign investment was adopted in 1999 and amended in 2002 and 2003. It establishes, inter alia, the principle of national treatment for foreign investors and their right to engage in any form of investment activity allowed by law. It also guarantees investors compensation in the event of expropriation and authorises the repatriation of profits. Nevertheless, sector-specific formal restrictions remain in a number of important fields of activity, including insurance, banking, mass media, aviation, land transport, agricultural land, electric power and natural gas.

While foreign trade has grown strongly in recent years and has made an important contribution to sustaining the economic expansion, ${ }^{46}$ levels of FDI have so far been disappointing, despite the liberalisation described above. The cumulative stock of FDI in Russia totalled just USD 26bn at the end of 2003, equal to just about half the annual FDI inflows to China during 2002 and 2003. Russia's stock of FDI is also well below that of the more advanced transition countries, in both absolute and per capita terms. FDI inflows into Russia amounted to just USD 26.7 per capita in 2002, as compared with figures of USD 88.6 for Hungary, 106.1 for Poland and 817.8 for the Czech Republic. ${ }^{47}$ Such low levels of FDI are a problem, for at least two reasons. First, overall investment rates are still relatively low. Despite a significant recovery in 2001-03, gross fixed capital formation amounted to just about 20 per cent of GDP

45. There are, however, far fewer duty-free lines than would typically be found in an OECD economy. See Kalinova (2005) for details.

46. On the importance of exports for Russian growth, see OECD (2004a:34-5, 56-7).

47. OECD (2004b:29). 
in 2003, slightly below the OECD average and well below the levels found in fast-growing emerging economies. Secondly, Bessonova et al. (2003) find that competition with imports and with firms that have benefited from FDI has a positive impact on the productivity of domestic firms. FDI flow flows are increasing, to be sure: according to data from the Federal Service for State Statistics (FSGS), gross FDI inflows rose to just under USD $6.8 \mathrm{bn}$ in 2003, after having fluctuated in the range of USD 4.0-4.4bn throughout 1999-2002. Preliminary data for 2004 show a further increase of about 40 per cent year on year, reflecting partly the desire of foreign investors to enter a fast-growing market and partly also international oil companies' drive to replenish their reserves by acquiring stakes in Russian oil companies. This is still a fairly modest inflow, given Russia's size, and it must be set alongside evidence of a slowdown in overall investment growth in 2004. Domestic investors, unsettled by signs of deterioration in the investment climate, were cutting back on investment in Russia in favour of acquiring assets abroad.

It is extremely difficult to quantify the impact of trade reform or opening up to FDI on economic performance. OECD (2001:9-10) observes that there is a positive association between trade openness and growth in transition countries but stops short of asserting a causal link between the two, as there is no simple way to isolate the effects of trade/investment liberalisation from those of other policies, let alone from the movement of macroeconomic variables such as the exchange rate and shifts in the terms of trade. There is, however, a strong consensus in both theoretical and empirical work in recognising the importance of trade in fostering economic growth, particularly by diffusing technological progress, making it possible to exploit economies of scale and enhancing competition. The significance of the last of these factors is all the greater in the Russian case in view of the highly concentrated structure of many sectors of the Russian economy. Foreign competition for product markets has a critical role to play in safeguarding competition while preserving the efficiency gains that can flow from industrial consolidation.

As noted above, such empirical work as has been done on Russian trade and FDI liberalisation to date suggests that they have had a positive effect on domestic firms. In particular, Bessonova et al. (2003) find on the basis of firm-level data that the increased availability of imported inputs helped improve the productivity of domestic firms during 1995-2001 (although the 1998 rouble devaluation did hit firms dependent on foreign inputs) and that competition with foreign imports and with goods produced by foreign-owned firms in Russia does lead to faster restructuring of domestic enterprises. However, they also argue that the benefits of trade and FDI liberalisation depend on other policies, including financial sector reform, measures to improve labour mobility and reductions in regional bureaucracy. These conclusions dovetail with the analysis of industrial competitiveness presented in OECD (2004a), which draws attention to the impressive productivity improvements recorded in sectors with exceptionally high levels of foreign participation. Yet while FDI has in some cases brought significant benefits to specific sectors or localities, it has so far been too small to contribute much to overall economic growth: even at regional level, there appears to be no significant relationship between FDI inflows and growth. ${ }^{48}$

\section{Russia's privatisation policies have attracted much criticism}

Privatisation has proved to be the most controversial major strand of reform. Before examining its impact, therefore, it is crucial to 'put privatisation in its place'. One of the major lessons to emerge from the experience of Russia and other transition countries has been that the significance of privatisation on its own was greatly exaggerated at the beginning of the market transformation. The effects of privatisation depend hugely on context and are thus inextricably linked to changes in the wider economic environment. In particular, they depend on the imposition of hard budget constraints on enterprises, as well as on developments with respect to competition policy, changes in corporate governance and the development of capital markets and other institutions favouring the emergence of a competitive, smoothly functioning market in corporate control. Thus, Angelucci et al. (2002), using data from a large enterprise-level panel

48. $\quad$ See Ahrend (2002). 
designed to address the determinants of privatised enterprise performance in Russia, find strong complementarities between four factors that, taken together contribute to significant improvements in enterprise performance: private ownership; good corporate governance; market structures and competition; and hard budget constraints. This confirms the view that these factors need to be considered jointly. While some critics have tended to attribute Russia's economic travails in the 1990s to flawed privatisation, the evidence actually suggests that the impact of privatisation on performance was positive.

That said, the privatisation mechanisms employed in Russia undoubtedly created problems of their own and are hardly above criticism. Voucher privatisation did succeed in transferring ownership out of the hands of the state, which had proved to be an extremely inefficient owner. However, the resulting structure of ownership reflected political necessity rather than economic efficiency. In fact, the authorities recognised ex ante that the voucher scheme would produce an economically inefficient ownership structure - a pattern of dispersed ownership in which enterprises were substantially controlled by insiders (mainly managers) with little interest in restructuring. However, they believed that rapid privatisation would make portfolio investment and acquisitions possible. A secondary market in corporate control would quickly transform the initial post-privatisation ownership pattern into a more efficient one, in which control passed to effective owners with both the means and the inclination to restructure. However, the transition from stage one to stage two of this process proved to be extremely difficult, not least because Russia lacked the sort of institutions that might resolve, or at least ameliorate, the corporate governance problems posed by the initial pattern of insider control. Russia's bankruptcy laws were extremely weak and the protection of creditors' and shareholders' rights very poor. In this respect, Russia's experience was typical of economies that opted for rapid mass privatisation programmes.

In the absence of hard budget constraints, effective competition and functioning capital markets, insider managers were able to entrench themselves and to resist both restructuring and liquidation. Operating in an environment of extreme political and economic uncertainty and aware of the limitations of their own newly acquired property rights, large numbers of managers opted for asset-stripping and capital flight over investment and restructuring - a rational, if unattractive, strategy in the circumstances. Given the absence of any effective control of management by shareholders and an almost total lack of protection of minority shareholders, managers often found it easy use their positions to expropriate the assets of other stakeholders. Moreover, dispersed ownership often gave rise to conflicts - many of them violent - among shareholders seeking effective control. Unsurprisingly, restructuring did not become much of a priority as long as asset-control contests were under way. Given the weak protection of property rights, control contests were often zero-sum: those who prevailed and secured controlling stakes were often able to exploit, if not drive out, minority shareholders.

The loans-for-shares deals have, if anything, generated even more criticism than the voucher scheme. Loans-for-shares substantially undermined the legitimacy of private ownership of large industrial assets. They also weakened the popular support for the protection of property rights, and they have therefore been haunting Russian big business ever since. That said, most of the enterprises involved were in very bad shape by the mid-1990s. ${ }^{49}$ Their main assets were legal claims to valuable reserves of natural resources, although these claims were often legally ill defined. The low prices involved thus to some degree reflected real political and commercial risks, as well as the determination of those involved to exclude outsiders. In this connection it should be noted that, for all the attention focused on them, the loans-for-shares deals were unique only in their transparency: both the auction processes and the sums involved were widely publicised. However, there is no reason to believe that the insiders who secured stakes in extremely valuable companies outside the collateral auctions actually paid any more than the loans-for-shares tycoons. In reality, the loans-for-shares deals are perhaps better understood as a further stage in the insider

49. In this connection, it is worth noting that Yukos was among the most troubled of Russia's oil companies at this stage, and its chief producing subsidiary, Yuganskneftegaz, was virtually bankrupt. 
privatisation that began in the late Soviet period and continued during the voucher phase of 1992-94. In every loans-for-shares auction but one, the lenders involved already had a significant degree of control over the companies they acquired. ${ }^{50}$ In short, insider privatisations tended to predominate in Russia no matter what mechanisms were used, and where asset privatisation did not take place, enterprise insiders often 'privatised' financial flows, siphoning funds and assets from state enterprises into vehicles they controlled.

The give-away nature of the voucher scheme and the low valuations used in most subsequent sales mean that privatisation proceeds have been very modest compared to the value of the assets realised, even when the value of those assets is discounted to reflect the undoubted political risks involved and the enormous difficulties of securing effective control over a Russian enterprise even after purchasing it. In 1997 (until 2004, the peak year for privatisation revenues), income from the sale of state property totalled 0.9 per cent of GDP. In most years during 1992-99, privatisation income was around 0.1 per cent. The sale of state property generated no more than about 1 per cent of the revenues of the consolidated state budget in the 1990s. ${ }^{51}$ The fiscal benefits of privatisation on the expenditure side are more difficult to assess. One of the major aims of privatisation was to separate non-viable enterprises from the budget, but privatisation failed to prevent government bodies at all levels from extending a range of implicit and sometimes explicit subsidies to distressed enterprises. ${ }^{52}$ That said, the experience of other transition economies, where privatisation was much slower, suggests that these subsidies would probably have been greater still had the recipients remained in the state sector. ${ }^{53}$

The fiscal benefits of privatisation have thus been modest, especially when compared with the value of the assets involved. While this cannot be regarded as good news, it is hardly surprising. Russian privatisation has not (with a few exceptions) been oriented primarily towards fiscal ends. Moreover, the insider-oriented nature of the process means that it has largely involved the transfer of assets to those enjoying de facto informal rights over them prior to privatisation (i.e. to insiders) at very low prices. As Alexeev (1999) observes, this suggests that privatisation served largely to formalise, and perhaps to magnify to some degree, pre-reform control over assets. ${ }^{54}$

\section{Nevertheless, the evidence suggests that privatisation has improved enterprise performance}

In assessing the contribution of privatisation to overall economic performance, it is crucial to distinguish between the process by which state assets were transferred into private ownership and the impact of that transfer on the privatised enterprises. While the defects of Russia's privatisation process cannot be denied, they should not obscure the fact that the evidence strongly supports the proposition that privatisation has improved enterprise performance. Indeed, for all the opprobrium heaped on Russian privatisation policies, it is difficult to find any serious empirical study that does not show positive effects of privatisation on restructuring. ${ }^{55}$ This holds true even for enterprises privatised to insiders during the

50. The exception was Norilsk Nickel. Oneksimbank, which bought the Norilsk stake, met fierce resistance within the company and had to fight a protracted battle to assert its rights as owner.

51. The exception here, too, was 1997, when a catastrophic shortfall in tax revenues was partially offset by a handful of large privatisation sales, amounting to 3.3 per cent of gross revenues.

52. Unpenalised tax arrears and arrears on gas/electricity bills were among the most common forms of implicit subsidy.

53. On Romania, in particular, see Ahrend and Oliveira Martins (2003).

54. Indeed, in some cases, these rights already existed de jure (e.g. occupiers of flats who were able to privatise them for nominal sums).

55. See Tompson (2002) for an overview of around 50 empirical studies of various aspects of Russian privatisation. 
voucher phase, and for companies involved in the loans-for-shares schemes, as well as for companies sold off in other ways. While studies vary widely in their assessments of the extent and speed of change, virtually all of them evidence of improved performance after privatisation. In particular, they find higher average productivity and faster productivity growth in privatised enterprises, as well as faster sales growth. Privatised firms tend to shed excess labour more rapidly than state-owned firms and are far more likely to change product lines, invest in new equipment and adopt forms of remuneration linked to productivity. These findings suggest that Russia's experience is typical of transition economies generally. ${ }^{56}$ Critically, the positive effect of privatisation is stronger in economic magnitude and statistical significance as the time elapsed since privatisation increases. Enterprises privatised for less than two years differ little from stateowned enterprises in their performance. In contrast, enterprises privatised for three years or more significantly outperform state-owned enterprises.

Nevertheless, the empirical work done on Russian enterprises confirms that the method of privatisation can make a difference. For example, a good deal of research suggests that the beneficial effects of privatisation were most pronounced where a strong outside owner had emerged. However, the extent of the problems arising from insider control should not be exaggerated. First, performance improvements were observed even where insiders retained control of companies after privatisation. Secondly, despite the under-developed nature of Russian capital markets and the absence of a real market in corporate control, there were substantial post-voucher changes in the structure of ownership, generally in the direction of more concentrated (and thus, in the Russian context, more effective) ownership. Thirdly, the problem was not that insider ownership was necessarily a bad thing but rather that, in Russian conditions, insider control made real market-oriented restructuring less likely. Managers often found it more lucrative to concentrate on informal profit-seeking (i.e. asset stripping and other forms of theft) while workers' chief concern was job preservation. In theory, of course, market disciplines should have compelled insiders in failing enterprises either to restructure or to surrender control to those who could and would do so. As those disciplines have become more effective - in other words, as the authorities have become less willing to prop up failing firms - the problem has become far less acute.

A further point to be made in respect of privatisation's contribution to growth is simply that the Russian state has proved to be an extremely inefficient owner of those assets that it continues to hold as state property. The track records of most large, state-owned companies in Russia would appear to be strong prima facie arguments in favour of privatisation. As a rule, output and productivity have tended to grow much faster in sectors that are relatively free of state ownership and interference. ${ }^{57}$ Moreover, in sectors such as oil, where there have been private and state-controlled companies operating side by side, private companies have generally been much more efficient. ${ }^{58}$

The foregoing should not be taken to imply that Russian privatisation achieved all that it might have done. Many criticisms of the process are clearly valid, not least those which focus on the way in which the chaotic and often corrupt privatisation processes of the 1990s have made it difficult to secure and legitimate the post-privatisation property settlement. ${ }^{59}$ There is little doubt that the continuing insecurity of property rights in Russia today is partly the result of past privatisation processes, and that this has hurt

56. See, e.g., Claessens and Djankov, 2002.

57. Ahrend (2004b).

58. See OECD (2004a:125-7).

59. This is a political problem as well as a legal one, since polls consistently confirm the Russian public's view that the privatisations of the 1990s were fundamentally illegitimate. See ROMIR's July 2003 survey at http://www.romir.ru/socpolit/socio/2003/07/privatization.htm. According to the ROMIR data, 88\% of respondents believed Russian big business had been formed by wholly or predominantly dishonest means and $77 \%$ favoured a reconsideration of the results of privatisation. 
economic performance. There is also good reason to believe that renewed insecurity about property rights contributed significantly to the slowdown in fixed investment and in the growth of a number of key industrial sectors, including oil, during $2004 .^{60}$

\section{Financial sector development has so far produced only limited benefits to the economy as a whole}

The banking sector and financial markets are both rather small relative to GDP and their role in financing productive investment is still limited. ${ }^{61}$ The insurance sector is even more under-developed. While all three sectors are now growing rapidly, further reform will be essential if they are to develop over the long term and to perform the functions normally expected of them in a market economy. This is an important reform priority, as a growing body of research has substantially strengthened the case for a 'positive, first-order relationship between financial development and economic growth ${ }^{62}$ in both developing and developed economies. Moreover, analyses of post-communist states, in particular, suggest that more efficient financial intermediation does indeed contribute to economic growth. ${ }^{63}$ The evidence also lends credence to the view that the intermediation-growth link is stronger for less financially developed countries, such as Russia. There are thus good reasons to believe that the development of the financial system in general, and the banking system in particular, will be critical to sustaining strong growth of investment and output in Russia over the longer term.

Fifteen years after the emergence of the first commercial banks in Russia, the Russian banking sector remains small, fragmented and dominated by a few state-owned institutions. While formal barriers to foreign banks' entry have been relaxed, the foreign presence in the sector is still limited. Despite very rapid growth after the 1998 financial crisis, banking sector assets amounted to just over 42 per cent of GDP in 2003, well below the levels of the more advanced transition economies of Central Europe and a small fraction of the levels typical of EU member states (Table 2). The deposit base, though growing rapidly, is still relatively small, and credits to non-financial enterprises and organisations in 2003 had reached just about 17.3 per cent of GDP. Bank credits financed only about 4.8 per cent of fixed investment in 2003 . Ownership structures tend to be opaque and there is little trust among banks, or between banks and clients with whom they have no ownership or other ties. The sector thus remains highly segmented. The interbank market is under-developed, and there is little of the interaction among banks typically found in a well functioning network of financial intermediaries. There is little pooling, trading or sharing of risk. ${ }^{64}$ Thus, bank portfolios tend to be highly concentrated on both the asset and liability sides, and a large share of lending is still to related parties.

60. For details, see Ahrend and Tompson (2004b).

61. See OECD (2004a), chapter 5, for details.

62. Levine (1997:688). See, in addition to Levine (1997), King and Levine (1993); and Levine and Zervos (1998). Levine and his collaborators highlight the importance of indicators of financial-market development as predictors of subsequent economic growth, while Demirguc-Kunt and Maksimovic (1998) and Rajan and Zingales (1998) emphasise the microeconomic argument, showing that financial institutions are crucial for firm and industrial expansion. Tadesse (2001) finds that the intermediation-growth link is, moreover, stronger for less financially developed countries (cited in Berglof and Bolton, 2001).

63. Koivu (2002).

64. Hainsworth, Yeremenko and Tubin (2001). 
ECO/WKP(2005)17

Table 2. Banking sector development in selected economies

2002

\begin{tabular}{lrrrrr}
\hline & Russia & Hungary & Poland & Czech & EU \\
\cline { 2 - 6 } Per capita GDP (USD) & 3100 & 5150 & 4600 & 5500 & 26000 \\
No. of banks & 1329 & 64 & 64 & 37 & 7219 \\
Per cent of foreign capital & 5 & 66 & 69 & 94 & n.a. \\
Assets, per cent of GDP & 38 & 72 & 67 & 121 & 280 \\
Credits, per cent of GDP & 20 & 32 & 26 & 36 & 118 \\
Capital, per cent of GDP & 5 & 8 & 8 & 7 & 120 \\
Deposits per capita (USD) & 350 & 2700 & 2400 & 4850 & 17500 \\
\hline
\end{tabular}

Source: CBR, World Bank, BIS statistics.

Russian financial markets are in a similar situation. After more than a decade of development, they have begun to acquire the technical and functional characteristics of mature markets. However, though growing rapidly, they are small and generally illiquid. While total stock market capitalisation in early 2004 was relatively high for an emerging market, at around USD 200bn (almost 50 per cent of GDP), indicators of liquidity and depth were still poor. The shares of only about 7-10 companies (mainly in oil and gas) accounted for around 90 per cent of turnover on the two major stock exchanges. The corporate bond market more than doubled in size in 2003, but the volume of placements amounted to only about 1 per cent of GDP. Activity is somewhat more diversified than on the stock market: the oil and gas sector accounts for only about 40 per cent of outstanding issues. Somewhat larger than the corporate bond market is the market in unsecured promissory notes (vekselya), where about USD10bn was outstanding at the end of 2003. Though vekselya are popular as a liquidity management instrument, they are a riskier investment than corporate bonds, as their issuing requirements are less demanding and their legal status is less well defined. ${ }^{65}$ Domestic financial markets thus remain a very limited source of investment capital. Even the government debt market is under-developed: the total volume of rouble-denominated government debt outstanding at end-2003 was equal to roughly 5 per cent of GDP, but only about 40 per cent of this was tradable - and a very large share of that was held by state-owned banks anyway. This is a problem, as the absence of a liquid, well functioning market in government debt deprives the CBR of a potentially important instrument with which to manage the money supply and sterilise foreign exchange inflows. It also limits commercial banks' opportunities for managing their liquidity and impedes the development of a proper market for interest-rate formation. ${ }^{66}$

The insurance industry is even less developed than the banks and capital markets. Over 2,000 insurances companies were created in the 1990s, but the vast majority were under-capitalised entities created to meet the needs of their owners. Estimates of the prevalence of such 'pocket' or 'captive' insurances vary widely, but there is no doubt that they still constitute most of the sector. One recent Russian study estimates that only about 10 per cent of premium income in 2002 was paid at arm's length - that is, paid by customers to insurers with which they were not linked by shareholdings or similar ties. Companies which insure themselves are not so much securing insurance cover as using insurance to write off expenses and avoid taxes. This is particularly true with respect to life insurance. In 2002, it was estimated that over 80 per cent of Russia's life insurance business consisted of tax-free salary enhancement schemes. No one really knows what proportion of the non-life sector's business consists of such 'grey

65. Vekselya are also cheaper to issue than bonds, as the latter incur stamp duty, although this has recently been cut.

66. In theory, government debt, as the least risky investment available, should provide a baseline interest rate against which rates on other instruments could be assessed. 
schemes', but a recent Russian analysis concluded that just 36 per cent of premium income in 2003 consisted of real insurance. ${ }^{67}$ Tax changes adopted in recent years have greatly reduced the scope for employing such schemes, but they have hardly been eliminated: the Federal Insurance Inspectorate estimates that 'grey schemes' accounted for more than 40 per cent of premium income in 2003. Some Russian insurance companies estimate that the true figure is closer to 65 per cent.

Given the limits on Russia's current ability to attract foreign investment and on the capacity of firms outside the resource sectors to finance investment from retained earnings, Russian growth will depend to a great extent on the effective mobilisation and intermediation of domestic savings. ${ }^{68}$ Moreover, a more efficient financial system could also play a role in fostering the diversification of economic activity in Russia. At present, the lack of mechanisms for efficiently allocating investment resources across economic sectors is a major problem. Indeed, the financial system in its current state arguably reinforces Russia's existing economic structure rather than facilitating change. In light of these considerations, the limited economic benefits of financial sector reform to date must be regarded as one of the disappointments of the Russian transition.

\section{Russia's experience shows both the benefits of competition and the need for stronger competition policy}

The performance of various Russian industrial and service sectors since 1992 has underscored the benefits of competition for economic performance, particularly in conjunction with privatisation. As noted above, a good deal of research on privatisation emphasises its interaction with such factors as competition and market structures. Other work suggests that privatisation had a greater impact on firm performance in markets that were competitive and were dominated by privatised enterprises than it did where the privatised concern faced competition chiefly from state-owned enterprises - a reflection, in many cases of the distortions that can occur if state-owned producers enjoy privileged positions in markets. ${ }^{69}$ The impact of powerful incumbents on entry may go some way to explaining why so many of the most dynamic sectors in Russia are relatively new activities (e.g. mobile telephony), where competition among providers has developed in the absence of an already existing dominant firm or group of firms. Overall, productivity performance has generally been better in sectors characterised by robust competition and it has been notably poor in sectors still dominated by state-owned companies enjoying substantial monopoly power. ${ }^{70}$ This underscores the importance of policies and institutions designed not only to safeguard but to promote competition.

Russia created its first competition authority early in the transition period and has since developed a substantial body of competition law. Both the Constitution and the Civil Code express strong support for competition as well. Given the centrality of robust competition to the creation and operation of efficient markets, this is hardly surprising. However, competition policy has often been less of a priority in practice than it has on paper. Successive Russian competition authorities (the name and status of which have changed frequently) have tended to be over-stretched, under-empowered and under-resourced. Instead of focusing narrowly on protecting and promoting competition, the competition authority was assigned numerous additional duties. However, it was not generally provided with staffing and resources to cope with its large - and frequently changing - range of duties, and it was endowed with relatively weak investigative and enforcement powers as regards its core competition role. In the spring of 2004, the Ministry for Anti-Monopoly Policy was liquidated in conjunction with the broader reorganisation of the

67. Rubin (2003); Vedomosti, 20 September 2004.

68. Tadesse (2001), cited in Berglof and Bolton (2001).

69. See Blasi et al., 1996:135-9; see also Barberis et al. (1995) for evidence of the benefits of competition in retail trade.

70. Ahrend (2004b:8-10). 
federal executive and replaced by a new Federal Anti-Monopoly Service. The service's mandate is actually somewhat more focused than the ministry's was, since consumer protection and utilities issues have been shifted away from it. While it is too early to assess the impact of this change, the narrowing of the service's mandate is probably a step forward for competition policy.

\section{Judicial reforms have ended some abusive legal practices but the administration of law remains uneven}

An extensive package of judicial reform legislation was adopted beginning in late $2001 .^{71}$ This included, among other measures, a new code of civil procedure, as well as a new procedural code for the arbitration courts, part 3 of the Civil Code, and new laws on the status of judges and on the constitutional court. The adoption of these statutes, which faced considerable opposition from an array of vested interests, represents a significant achievement. Of particular importance was the clarification of the respective jurisdictions of the arbitration courts and the general civil courts. Their jurisdictions used to overlap. Disputes could and did run in parallel in both systems, often with one side winning in the arbitration court and the other in the court of general jurisdiction. This often reflected non-legal factors (each side would sue in a court over which it expected to enjoy some influence) but it also reflected differences in the law the two types of court applied. In the absence of a single supreme authority, there was no way to determine which judgement took precedence. ${ }^{72}$ A further important step was the reduction in the supervisory role of the procuracy, which previously had considerable power to challenge court rulings with which they disagreed on the grounds that the rulings were contrary to the public interest. This was true even of cases in which the state was not involved. As a result of prosecutorial interventions (often initiated on the basis of political or other considerations), victors in civil cases often found their awards overturned and their cases returned to the court of first instance for re-trial. The passage of new legislation cannot of itself ensure that the law is fairly and consistently applied - a challenge that largely remains to be overcome. However, the new measures did put an end to a number of abusive legal practices that had arisen in the 1990s as a result of gaps in the law and contradictions between different pieces of legislation.

\section{The law on technical regulation is potentially a major step forward for regulatory governance}

A major weakness of Russian economic policy since 1991 has been the relative neglect of regulatory governance policy, in the sense of developing the capacity to initiate and enforce cost-effective, 'fit-forpurpose' regulations and regulatory regimes. This has begun to change, not least as a result of the adoption in December 2002 of a new law on technical regulation. ${ }^{73}$ The law set in motion a major review of around 60,000 norms and regulations concerning the certification of products on environmental, health, safety and other grounds. Many previously mandatory norms will become voluntary, while others will be scrapped altogether. Moreover, the law outlines new procedures for proposing, evaluating and adopting new standards and regulations. If implemented in full, these procedures will make the regulatory process more predictable, transparent and inclusive, facilitating widespread consultation and full assessment of the potential economic impact of new regulations. The procedural provisions of the law also emphasise the need to avoid discriminatory or unnecessarily restrictive measures, to apply internationally recognised standards where possible and to recognise the equivalence of other countries' regulatory measures. The procedural aspect of the reform represents a major breakthrough for Russia, and it is to be hoped that this focus on reform of the regulatory process (as opposed to the substance of regulation) will be replicated in other spheres. If implemented fully and consistently, the reform of technical regulation should result in a

71. For more detail on the judicial reform package, see Tompson (2001). For the texts of the procedural codes, see GPK (2002); APK (2002).

72. Courts of general jurisdiction are subordinate to the Supreme Court but the arbitration courts are under their own Supreme Arbitration Court, over which the Supreme Court has no authority.

73. See OECD (2204a:89) for details of the law. 
major reduction of the regulatory burden on business, particularly in manufacturing sectors. Given the importance of technical regulation as a barrier to market entry and product development, the reform will also reduce a major constraint on innovation and the introduction of new products. It may therefore serve, at least at the margins, to facilitate the diversification of economic activity. Nevertheless, much remains to be done - the implementation period set out in the law is no less than seven years, and Russia is still a relative newcomer to the idea of a formalised and central regulatory governance policy.

\section{'De-bureaucratisation' legislation has helped to reduce the bureaucratic burden on private firms}

In an effort to reduce bureaucratic rent-seeking and to create a more favourable climate for small and medium businesses, the government in 2001-02 secured the adoption of a trio of laws that reduced the range of activities subject to licensing requirements, streamlined procedures for registering new businesses and reduced officials' power to conduct arbitrary inspections of enterprises by the police, fire, sanitation, tax and other authorities (often an occasion for the extraction of bribes) ${ }^{74}$ Another law, further simplifying registration procedures, was adopted in October 2003. These measures have had a positive impact, but survey data suggest that implementation has been uneven. Small-business surveys conducted under the auspices of the World Bank and the Centre for Economic and Financial Research (CEFIR) show that matters improved with respect to all three problems after the laws were adopted, but the picture varies from region to region and it is clear that many officials do not adhere to the new legislation. It also appears that progress slowed significantly in 2003:

- Licensing requirements (both formal and informal) have been substantially reduced, but they remain more widespread than the law allows, and the time and cost involved in obtaining them rose substantially in 2003. The average cost of a licence issued more than quadrupled between early 2002 and late 2003, while the time involved increased by 14 days on average. ${ }^{75}$

- The number of inspections, both planned and unplanned, fell steadily during 2001-03, but they were still in many cases far more frequent than permitted under the new legislation. Moreover, around half of unplanned inspections were conducted without a warrant, and multiple inspections remained common. A second inspection by a state body increased the probability of still further inspections by anywhere from six to fifty times, depending on the agency involved. The survey data show no evidence of a reduction in the amount of bribery, and, indeed, financial losses from inspections rose in 2003, after falling in 2001-02. Around 62 per cent of payments to police following inspections were described as 'unofficial'.

- Registration appears to be the area of greatest improvement. The CEFIR survey data show that registration became significantly simpler and faster during 2001-03, while reliance on professional intermediaries, acquaintances and bribes in the registration process declined markedly.

The importance of such measures is all the greater in view of the increasing evidence of dynamism in Russia's small business sector. While the official data on small business are problematic, the evidence suggests that this sector has also developing relatively rapidly in recent years, albeit from a very low base. This holds true even when adjusting for the unusually large role played by unincorporated entrepreneurs

74. For details, see OECD (2002:80-104).

75. It should be acknowledged that this is partly a result of the reduction in the number of licensed activities. However, this reduction should be reflected primarily in the changes between round 2 and round 3 of the CEFIR surveys. Yet there were large increases in time and money spent between rounds 3 and 4 as well. 
(the so-called PBOYuL) ${ }^{76}$ in the small business sector. ${ }^{77}$ This is important because PBOYuL do not currently appear in official statistics covering the small enterprises' (SE) sector. The number of people working in the SE and PBOYuL sectors is roughly of the same order of magnitude, and together they account for somewhat above 20 per cent of the work-force. While the small business sector is thus larger than usually claimed, it is still relatively small by the standards of OECD countries or the more advanced transition economies. In the OECD area, it is not unusual for more than half of the labour force to works in SMEs. The available data suggest that the combined SE/PBOYuL sector has been growing at around 15-20 per cent per year since 2001, with growth accelerating to around 30 per cent in $2003 .^{78}$ The acceleration in 2003 was mainly driven by the ongoing consumption boom, as witnessed by particularly strong increases in the retail sector and transport. Creating conditions that favour the emergence and development of more small businesses - especially in sectors where they remain few and far between, such as manufacturing - provides an important way not only to help sustain economic growth but also to foster the diversification of economic activity.

\section{Structural reform: the challenges ahead}

In assessing the most important structural reform challenges facing Russia, it is important to bear in mind not only the achievements just described but also the lessons for future reform suggested by Russia's recent history. First, it is important to note the extent to which the impact of the reforms discussed above did or did not reinforce one another. Thus, it is clear that the benefits of privatisation and competition appear to have been greatest in those sectors where both were present. Similarly, limited progress with respect to issues like the rule of law and corporate governance tended to reduce the beneficial effects of privatisation and undermined the development of the financial system. This suggests that complementarities among different strands of reform are more than just a theoretical issue. Secondly, it is clear from the foregoing that the basic institutional framework of Russia's new economy is still very much a work in progress. Much more remains to be done to strengthen property rights, establish the rule of law and foster competition in product markets. While the Russian authorities have embarked on some impressive - and often technically complex - 'second-generation' reforms in fields such as electricity restructuring, many 'first-generation' reforms, concerned with creating the basic institutions of a market economy, have yet to be completed. Perhaps the most fundamental first-generation task is the creation of a legal system on which economic agents can rely for timely, effective enforcement of contracts and protection of property rights.

In general, the most difficult reform challenges have been those concerned with changing, rather than merely reducing, the state's role in the economy. Thus, measures that require the state to refrain from regulation have generally been relatively easy to implement, once adopted. In particular, the most important liberalising measures of the transition - price and trade liberalisation - were implemented relatively quickly in the early $1990 \mathrm{~s}$, albeit with some significant exceptions. It has proved far more difficult to implement reforms that entail the creation of new institutions and new, market-oriented forms of regulation, such as competition policy or the reform of its infrastructure monopolies. Increasingly, these are the challenges that dominate Russia's reform agenda.

76. PBOYuL is the Russian acronym for predprinimatel' bez obrazovania iuridicheskogo litsa ('entrepreneurs without the formation of a legal person').

77. A great deal of activity that in other countries would be carried out by small companies is in fact done by PBOYuL in Russia.

78. It should be borne in mind that, owing to the limitations of the available data, these estimates are necessarily very rough. 


\section{ECO/WKP(2005)17}

\section{Improving the quality of state institutions is the key priority}

By the end of the 1990s, both the Russian authorities and many outside observers had come to regard the reform of state institutions themselves as the most important reform challenge facing Russia. If privatisation, the elimination of subsidies and macroeconomic stabilisation dominated the reform agenda in the early years of the market transformation, attention has in recent years been focused on reforming the courts, the civil service ${ }^{79}$ and the major regulatory institutions, as well as recasting relations between the federal centre and sub-national governments. However, progress in rebuilding state capacities has been very uneven. Since 1998, there has been a dramatic strengthening of the state's extractive capacities - its ability to tax - and of its rule-making capacity. The latter largely reflects increasing executive dominance of the legislature. However, the same cannot be said of rule enforcement. Doubts about the independence, competence and probity of the courts, the prosecutors and the police persist. Moreover, there remain good reasons to question the 'relative autonomy' of the state: state bodies are sometimes penetrated by, or even captive to, particular private interests - if not simply those of the officials who control them. These weaknesses undermine both rule enforcement and the Russian state's still limited administrative capacities. The state bureaucracy is large, often unresponsive to either the public or its political masters, and riddled with corruption.

These weaknesses impinge directly on the state's ability to devise, adopt and implement policies that make significant demands on the probity or administrative capacities of the state. This point is of particular relevance when considering the current debates over 'industrial policy' and economic 'diversification'. Whatever the merits of the various proposals for more a more activist industrial policy - and some of them are far more market-friendly than others ${ }^{80}$ - there remain good reasons to be sceptical of the bureaucracy's ability to implement them. At present, the Russian state performs its most fundamental domestic tasks, from law enforcement to social service provision, relatively poorly. In the absence of a major improvement in its ability to fulfil these essential functions, it is unlikely to be very successful in tackling more technically demanding policy challenges. Building an honest, effective state administration is arguably, therefore, the most important structural reform priority.

It is critical to recognise that successful reform will involve more than simply the recovery of capacities eroded or lost in the 1990s. Russia does not merely need a strong state; it needs a state different in kind to that which it inherited from the Soviet Union. Soviet administrative bureaucracies were chiefly concerned with directing economic activities, assigning economic tasks to agents and rewarding (or punishing) them for fulfilment (or non-fulfilment) of those tasks. The role of the state in a market economy, by contrast, is overwhelmingly regulatory. In most cases, the state's function is not to tell economic agents what ends to pursue but to act as an impartial referee and a provider of public goods in a marketplace full of autonomous actors choosing and pursuing their own ends. Unfortunately, the taskfulfilling mindset of the Soviet bureaucracy is often reflected in the behaviour of its Russian successor. Even after more than a decade of reforms, the state is still prone to rely too much on direct control over assets and intervention in markets; one of the chief aims of reform is to move towards greater reliance on law and regulation instead. Redefining the role of the state thus constitutes an important challenge.

The reform of state institutions in Russia involves a number of distinct strands. First, the general rubric of 'administrative reform' encompasses both the reorganisation of federal executive bodies undertaken in early 2004 and civil service reform. Secondly, as noted above, major reform of the judiciary

79. We use the conventional English term 'civil service' to refer to the permanent bureaucracy. The Russian term, 'gosudarstvennaya sluzhba' is more accurately translated as 'state service'. As will be argued below, this is not a purely linguistic point, as the difference in emphasis is reflected in the culture of the service. 
was undertaken in $2001{ }^{81}$ The 2001 package marked a major step forward, but much remains to be done to rid the courts of corruption and political influence. Thirdly, there is the on-going redefinition of the relationships among national, regional and local governments. Finally, there is still considerable work ahead in building capacities essential to good policy-making, such as improving the transparency and regularity of the policy process, and building more effective regulatory agencies. The discussion which follows does not attempt to address in detail all of these areas; rather, it aims to outline the nature of the challenges involved and the choices Russian policy-makers face in deciding how to deal with them, particularly in respect to the central issue of how to refashion the state bureaucracy.

\section{The reform of federal executive bodies got off to a rocky start}

A much anticipated reorganisation of federal executive bodies was undertaken in March 2004, after several years of debate. In an effort to streamline the government structure, it reorganised the federal executive into three types of institution, assigning a specific role to each:

- Federal Ministries are meant to be policy-making bodies. They engage in policy analysis, development and evaluation in their respective domains and are responsible for drafting new legislation. They coordinate and monitor the activities of federal services and agencies operating within their jurisdictions. The reform reduced the number of ministries from 23 to 15 , in an attempt to streamline government decision-making.

- Federal Services are supervisory and regulatory bodies. Funded from the state budget, they can issue individual regulations but not normative legal acts.

- Federal Agencies are direct providers of public services to the state and/or private sectors. Their funding can therefore come in part from charges and fees paid by their 'customers'.

On the face of it, the reorganisation appears to reflect a desire to separate policy-making, service provision and regulatory functions, which could in principle increase the efficiency of executive bodies while reducing the conflicts of interest that arise when these functions are combined. Unfortunately, there is as yet little evidence that the reorganisation has achieved either of these aims. First, it disrupted the work of many government bodies for much of 2004, as officials were preoccupied with organising the new structures and sorting out their respective roles. Secondly, the regulators continue in some cases to be subordinate to the ministries they regulate. There is still little indication that the Russian authorities are committed to creating regulatory organs that are genuinely independent and properly shielded from outside pressure, whether public or private. The subordination of the new Federal Anti-monopoly Service to the cabinet is a particularly striking instance, since the Service is required to evaluate many of the government's own acts.

\section{Civil service reform is likely to prove an even greater challenge}

The challenge posed by civil service reform in Russia is enormous. The administrative systems inherited from the Soviet regime were in many ways the exact opposite of the ideal of a public bureaucracy as it is understood in most OECD countries. ${ }^{82}$ The Western model, as reflected in the writings of Max Weber, emphasises a strict functional/hierarchical division of labour; the existence of career civil servants as a distinct group, formed on the basis of competitive recruitment and merit-based promotion; and a distinctive rationality based on legality, impartiality, objectivity and regularity; and a public-service ethos. A combination of relatively good salaries and security of tenure, as well as the presence of a relatively

81. For details, see OECD (2004a:88-9) and Tompson (2001).

82. See Goetz (2001:1033). 
clear career path, makes returns to investment in skills and tenure good enough to retain able administrators.

The Soviet administrative hierarchy, by contrast, rejected both the separation of political and administrative spheres and the autonomy of the administrative bureaucracy. The state administration was intertwined with, and penetrated by, the ruling party at every level. Recruitment was politicised in principle (resting on the party-administered 'nomenklatura' system) ${ }^{83}$ and often personalised in practice. The ruleoriented rationality of the Weberian model was rejected in favour of an overriding emphasis on the implementation of party decisions, which took precedence over legal norms. In the Soviet period, rule violations were often tacitly condoned in the interests of task fulfilment. Thus, Gosarbitrazh, the state body charged with resolving inter-enterprise disputes - and the body from which today's arbitration courts are descended - was expected to resolve disputes according to the law, subject to the requirements of plan fulfilment. If the law came into conflict with the need to fulfil plan tasks, it was the latter which tended to take precedence. Far from being characterised by a clear functional division of labour, the Soviet system was characterised by complex and often overlapping jurisdictions and lines of authority, which were intended to facilitate monitoring and control of officials by the political leadership. These are all enduring features of Soviet administrative practice: in most respects, the Russian bureaucracy today resembles its Soviet predecessor far more than any Weberian model.

The highly personalised nature of the administrative system inherited from the Soviet state merits particular attention. The Soviet administrative hierarchy, despite its complex and seemingly well defined formal institutions, relied heavily on an informal structure of personal networks within the party-state apparatus to function. Authority was often vested more in persons than in offices. Patron-client ties and the distribution of rewards generally mattered more than the application and enforcement of rules and formalised codes of behaviour. Such personalistic administrative structures tend to weaken state capacities by encouraging rent-seeking and corruption, and by raising the costs of monitoring and enforcement. Russia's early post-Soviet governments made little headway in addressing this problem. Indeed, such personalistic patterns of authority tend to be replicated by the still common practice whereby senior officials and politicians seek to bolster their authority over the institutions they run by securing the appointment of trusted personal associates to key posts. ${ }^{84}$ The implications of this situation for the design of any civil service reform are explored below.

The personalism which pervades the bureaucracy lies at the heart of one of the paradoxes of postSoviet Russia: it has a weak state but strong officials. The patronage dispensed by individual officials - particularly those charged with managing state property or large financial flows - can be enormous, while the weakness of the administrative machinery often makes it easy for individual officials to use this power to pursue narrow private or political ends. The Russian state could also be called a weak state with strong components. A number of specific institutions rate highly on criteria of cohesiveness and effectiveness. ${ }^{85}$ Yet in the absence of a strong co-ordinating centre, these institutions often pursue narrow institutional interests, working at cross-purposes with each other and with the government itself. This lack of cooperation has indeed been one of the main brakes on administrative reform. It is also the major reason

83. See Voslensky (1984).

84. It is no accident that post-Soviet Russia has seen continuity with respect to such practices: highly personalised administrative systems often emerge in periods of political instability, because they enable political elites to shore up their political positions and enhance the administrative capabilities of new states relatively rapidly. The problem is that they also tend to limit the development of those capabilities beyond a certain point.

85. The central bank, the privatisation agencies and some regional governments all fall into this category. However, the close ties of some of these bodies to specific private sector interests has sometimes raised questions about their autonomy. 
for the current concern with restructuring federal executive bodies in such a way as to facilitate more efficient policy-making and better policy implementation.

\section{The Russian bureaucracy has undergone massive change, but little reform since 1991}

Not all the pathologies that afflict the Russian bureaucracy can be attributed directly to the Soviet past: more than a decade of transition has also left its mark. The bureaucracy underwent dramatic changes during the 1990s, generally as a result of economic and political developments rather than any reform strategy: ${ }^{86}$

- The 1990s witnessed a large-scale exodus of personnel from the bureaucracy. Those most likely to leave were relatively well qualified mid-career officials, who could command much larger salaries in the private sector. Thus, the civil service today is substantially older and less well educated than its late Soviet counterpart, and mismatches between skills and duties are increasingly common. ${ }^{87}$ Moreover, there is clear evidence that the lower echelons of the public administration are dominated by women and younger workers, while the upper echelons tend to be dominated by older men, the bulk of whom began their administrative careers by about 1985 . Turnover among the former is very high, as the structure of the service gives younger officials little incentive to stay, while higher-level officials, many of whom are already pensionable, face little competitive pressure from below or outside the service. ${ }^{88}$

- There is compelling evidence that the problem of official corruption has grown markedly worse since 1991. This reflects a combination of factors, including the breakdown not only of the political and bureaucratic controls that existed in the Soviet system, but also of the norms and beliefs that (however imperfectly) supported the old order. ${ }^{89}$ Another critical factor is the very low pay received by officials, particularly as many low-paid functionaries find themselves disposing of very valuable state assets or managing substantial financial flows. Opportunities for personal enrichment grew dramatically in the post-Soviet period, even as officials' remuneration declined.

- The size of the bureaucracy has grown, but by no means as rapidly as is widely thought. In fact, the number of officials employed in public administration grew by just about 13.6 per cent during 1994-2001, with subnational administrations accounting for most of the increase. The balance of this growth occurred among federal employees posted in the regions: the central federal administrative apparatus shrank. The public administration actually employs an unusually small portion of the labour force when compared with most OECD and transition countries. ${ }^{90}$ Growth has partly resulted from the creation of the new agencies needed to regulate a market economy

86. The discussion in this paragraph draws on the analysis found in Huskey and Obolonsky (2003).

87. The 'graying' of the state bureaucracy is not unique to Russia; the US General Accounting Office reported in 2002 that more than 30 per cent of the people working for the FBI, the State Department and the Defense Department would be eligible to retire by 2006; Wall Street Journal, 19 September 2002.

88. Brym and Gimpelson (2004:108-10).

89. See Huskey and Obolonsky (2003).

90. See Brym and Gimpelson (2004:92-100) for details. It should be noted that comparisons across time and countries are complicated by problems of definition, including the creation of new types of officials and the reclassification of others in conjunction with the transition. 
(the bankruptcy service, the securities regulator, etc), but these bodies are, for the most part, still relatively small. ${ }^{91}$

\section{Box 4. Civil service reform, 1992-2004}

Civil service reform made little headway in the 1990s. The first steps, taken in 1995, represented a throwback to traditional caste or corporatist views of the bureaucracy, focusing on the status of officials, and their privileges, perquisites and protections. A much more ambitious set of proposals began to be developed from about mid-1997 under the Commission on State Construction (later the Commission on Administrative Reform). A draft strategy which aimed to turn the 'state service' into a 'public service' - a transformation that would require a dramatic shift in the culture and outlook of Russian officials - included proposals to make the bureaucracy smaller, more transparent and less expensive, and envisaged the possibility of contracting out to private firms some functions performed by the state. The 1997 draft also called for introducing competitive recruitment - which was required under legislation adopted in 1995 but never implemented. The draft encountered fierce resistance, however, and there was no further progress until the adoption in late 2001 of the Federal Programme for Reforming the State Service of the Russian Federation (2003-2005). The 2001 programme was largely based on the ideas contained in the 1997 strategy, and it, too, has met stiff opposition. The first legislation adopted pursuant to the programme was the 2003 law 'On the System of State Service of the Russian Federation'. Opposition to the bill from within the administration was clearly reflected in the fact that, while the original draft bill comprised 119 articles, the text that reached the statute books was only 19 articles long. A much longer law was adopted in 2004, setting out the basic framework for the non-diplomatic civil service.

The 2003 law is largely confined to enshrining in statute the goals and principles enunciated in the concept rather than in stipulating concretely how these are to be achieved. It makes reference to numerous issues to be resolved in accordance with other primary and secondary legislation still to be adopted. ${ }^{1}$ The law defines three types of state servant (civil, military and police) and states what other legislation shall form the basis for their activities. It also provides for a register of state service posts, sets a mandatory retirement age and stipulates that the rank-structures of all three branches of service will be co-ordinated so that transfers among them will be possible. In this, it resembles the pre-revolutionary 'table of ranks', which also ensured clear equivalence among military, police, civil service and even ecclesiastical ranks. Since it is difficult to imagine senior civil servants being put into high military or police posts, this has raised some concern that the new structure will facilitate the colonisation of the upper reaches of the civil administration by senior officers of the military, police and security services. The civil service law of 2004 goes further, outlining the legal status of civil servants and the procedures for appointing, evaluating and promoting them.

1. In this, it resembles its 1995 predecessor, 'On the bases of state service', which made reference to 79 other pieces of federal or regional legislation that were never subsequently adopted. As a result, the 1995 law remained a dead letter.

\section{There is still little clarity concerning the strategic direction of civil service reform}

Although reform of the bureaucracy has been actively discussed for several years, the strategic direction of the reform is still far from clear. The 2001 programme enunciates a number of worthy goals, including greater openness and accountability, a higher level of professionalism, the eradication of corruption and clearer legal definitions of the rights, duties and competences of civil servants. However, the concept is remarkably thin on specifics and says little about how these ends are to be achieved. It is difficult to see a clear model emerging either in the programme or in the various decrees and statutes adopted over the last few years. Many of the proposals seem to reflect the classic Weberian model. The 2001 programme seems to envisage the civil service as a distinct 'caste' made up of individuals spending lengthy careers in state service. Promotion will be for the most part within branches of service and based largely on seniority. However, both the programme and much of the discussion surrounding it also reflects the influence of the so-called 'new public management' (NPM) that has been very influential in the West - and particularly in the main English-speaking countries - since the early 1980s. Of course, Russia need

91. One might also note that little has been done to downsize the 'traditional' bureaucracies left over from the Soviet era, such as the Ministry of Agriculture. 
not make a stark choice between 'pure' Weberianism (an ideal type that does not exist anywhere in any case) and the wholesale adoption of the techniques of NPM. There will doubtless be elements of both in any reformed state administration and, indeed, both approaches find some reflection in the changes adopted in 2003-04 (see Box 4). However, consideration of the contrast between the two models can nevertheless help to illuminate some of the issues to be resolved in reforming the civil service.

Clearly, a serious attempt to refashion the state administration into something more closely resembling a classic Weberian public bureaucracy must address a long and difficult set of challenges. It will require a greater differentiation of tasks and personnel between the political executive and the administrative bureaucracy, the creation and application of a well designed system of administrative law, including effective legal controls over administrators' actions, and the creation of a professional, nonpartisan civil service, whose political neutrality is protected by appropriate institutional arrangements. Nevertheless, it could be argued that the Weberian model represents the logical endpoint towards which Russian reformers should direct their efforts. The implicit systems and models adopted in other postcommunist states seeking to overhaul their bureaucracies have also been Weberian. Countries like Poland and Hungary have largely steered clear of NPM approaches. ${ }^{92}$ However, some in Russia fear the 'conservative' potential of the Weberian model. They fear that a model of reform emphasising a relatively closed, career civil service, with hierarchical structures and the vertical integration of administrative structures, could easily be used to create a Weberian bureaucratic façade, behind which little real change might take place. The issue of open recruitment, in particular, is likely to be a critical one.

NPM-based proposals for administrative reform represent the major alternative to the creation of large, vertically integrated public bureaucracies on the Weberian model. The precise definition of NPM is even more elusive than that of the Weberian model; NPM is more of an approach than a model as such. NPM tends to be associated with competition, performance incentives, recruitment into middle and upper grades of the civil service, and more movement into and out of the service. It generally includes an emphasis on the centrality of the citizen/consumer to the whole process of public-service provision, as well as on the accountability of public-sector bodies (and even individual officials) for the results of their work. In this respect, NPM seems particularly relevant to those wishing to reorient officials from notions of 'state service' towards 'public service'. In order to enhance the quality of public services and the efficiency with which they are delivered, advocates of NPM also tend to favour the separation of policy-making from service provision, with the latter taken over by semi-autonomous agencies. Such agencies often operate in markets or quasi-markets, competing for resources with other public or private service providers. The separation of policy-making from service delivery is meant to free policy-makers from the burdens of existing service provision, while creating opportunities to provide performance incentives to actual service providers by putting agencies onto a contractual footing. Formally, at least, the March 2004 reorganisation of the federal executive reflects just such a desire to separate policy-making from service provision.

The implementation of NPM-style reforms would be more than a little problematic in the current institutional environment. NPM emerged in the West as a set of measures designed to reform traditional Weberian bureaucracies in order to make them more flexible and efficient. It thus tends to assume a more or less Weberian starting point, including clear lines of authority, a culture of rule-observance, and an understanding of officials' roles and duties in terms of the offices they hold rather than their personal connections. Successful NPM-based reforms also require predictable resourcing, credible regulation and monitoring of staff (to prevent malfeasance), and a generally sound contracting environment. NPM techniques are unlikely to achieve the desired results in an administrative system characterised by patronclient networks, and by low levels of transparency, accountability and respect for legal norms. Merit pay,

92. It is also noteworthy that western institutions involved in civil service reform efforts in Central Europe and Russia have also reinforced the tendency to focus on the classical model. See Nunberg (1999:264) and Goetz (2001:1034-5). 
incentives and more flexible recruitment could easily degenerate in such an environment into pork-barrel politics and patronage, except perhaps in situations where performance was really evident to external observers. This last point highlights the extent to which greater transparency will be crucial to any attempt to reform Russian public administration - particularly if reform is to change the culture of the bureaucracy.

Whichever overall orientation is ultimately chosen, the Russian authorities face a number of specific choices with respect to civil service reform, including:

- The degree of unity or diversity to be achieved. Historically, Russian ministries and other departments have operated according to rules, organisational cultures and career paths specific to each ministry or agency. The question of whether, or to what extent, Russia will maintain this tradition of separate arrangements for each major group of officials continues to be contested.

- The vertical integration of state administrative bodies. This partly concerns relations between federal institutions and sub-national authorities: the authorities have only recently begun to standardise civil service rules and practices across the three levels of government (federal, regional and municipal). A second issue, particularly in fields such as law enforcement, concerns officials serving in federal ministries and agencies who nevertheless work in the regions. Such 'territorial' federal officials are often heavily influenced - if not co-opted - by regional authorities.

- Recruitment and promotion. The legislation adopted in 2003-04 establishes a basis for competitive recruitment (though it leaves many permissible exceptions to this principle) and points to a model based on the recruitment into the initial grades of individuals who will become career civil servants. However, there remain issues to address concerning whether and under what circumstances individuals might be recruited into the service at higher grades and the establishment of promotion procedures that are transparent, efficient and fair.

- Civil service pay. There has long been wide agreement that raising officials' pay was a necessary, though by no means sufficient, element of any attempt to curb official corruption. Corruption will be hard to root out while public officials on very low salaries are called upon to take decisions affecting the interests of wealthy and powerful companies. The recent move to reduce the size of the federal administrative apparatus while significantly increasing officials' salaries is therefore to be commended. However, there is no consensus about how large the pay differentials within the service should be, how and by whom pay scales should be determined, whether or not meritbased pay or other such incentives should be employed, and whether or not to reduce the share of remuneration provided in-kind rather than in cash.

\section{Changes in the broader institutional environment will be crucial to the success of civil service reform}

It is clear from the above that civil service reform in the narrow sense - reorganising structures or redefining roles - is likely to achieve little on its own. It cannot be considered in isolation from the wider institutional environment. Indeed, changes in that environment probably matter more than the specific model of administrative reform the authorities pursue. Thus, whatever the ultimate shape of Russia's reformed public administration, there are a number of basic issues that will need to be addressed if reform is not merely to produce the old pathologies in new configurations. These include:

- Strengthening the rule of law. In particular, it is necessary to establish better protection of the independence of the courts against pressure or interference from state bodies or private parties. A truly rule-governed administration cannot function where the rule of law is not upheld. This will require, among other things, a greater willingness by state bodies to be bound by the law 
themselves and to make good on legal undertakings. There have been a number of episodes recently in which the state has unilaterally withdrawn from legal agreements or unilaterally chosen to prosecute actions it had previously acknowledged - implicitly or explicitly - as legal. This creates a kind of uncertainty about state behaviour detrimental to the interests of both ordinary citizens and private businesses.

- Increasing the transparency of state institutions. Real bureaucratic accountability - to ordinary citizens or elected politicians - will require greater access to both officials themselves and information about what officials are doing. This is likely to be resisted: recent survey work finds that civil servants at regional and local levels are generally opposed to greater transparency; there is little reason to believe that the views of federal officials are any different. ${ }^{93}$ Formal requirements for openness on the part of state agencies, necessary though they are, will probably not be enough to generate real transparency: no less critical will be more effective oversight of executive and judicial bodies by the legislature, by organs such as the Accounting Chamber, and by the press. A more independent press would also enhance both transparency and accountability.

- Strengthening civil society institutions. The state administration does not operate in a political or sociological vacuum: the extent to which it can be made accountable to the public is partly a function of the wider relationship between state and society. Cross-country research shows that both the rule of law and the development of civil society are strongly and negatively correlated with corruption levels. ${ }^{94}$ The evidence also suggests that a lack of press freedom causes corruption. ${ }^{95}$ Civil service reform would thus benefit not only from a stronger judicial system, but also from steps to foster the development of civil society and press freedom.

- Reducing opportunities for corruption. The laws and rules that bureaucrats administer can be made more corruption-resistant. Rules should be simple, transparent and standardised, with few exceptions and as little reliance as possible on bureaucratic discretion. Where discretion is required, the criteria that should determine officials' choices should be explicitly set out and their actions in most cases should be subject to some form of outside (administrative or judicial) review if need be. Many recent legislative changes seem to be at least partly motivated by this kind of reasoning, including changes to fiscal federal relations and measures to curb bureaucratic interference in commercial activity by, for example, curtailing officials' inspection powers, simplifying business registration and reducing the range of activities subject to licensing requirements. The draft law on the subsoil submitted to the government at the end of 2004 also included a number of provisions designed to regularise procedures and reduce the scope for arbitrary decision-making or corruption. One of the best reasons for avoiding unnecessary regulation is that it tends to create opportunities for corruption, and there is some evidence that superfluous regulations are often adopted or maintained for this very reason - officials are reluctant to give up the rents involved.

- Strengthening enforcement. While drafting corruption-resistant legislation is important, it will not on its own reduce corruption so long as crimes go unpunished. Those who try unduly to influence the decision making of judicial or administrative institutions must be brought to account in a fair, transparent process. This will require a good deal of political will, because big offenders are often wealthy private citizens or high-ranking officials. Moreover, a consistent approach to

\footnotetext{
93. Arkhangel'skaya (2003).

94. Brunetti and Weder (2003).

95. Ahrend (2002).
} 
enforcement will be needed in order to ensure that anti-corruption cases are not (and are not perceived to be) merely political or commercial weapons.

It is critical to note that such changes in the institutional environment will also help advance reform in other areas. In particular, they will facilitate - though not guarantee - improvements in private-sector institutions as well as in the state administration. To a significant extent, the opacity of Russian business and the complex (and often shady) structures used to exercise ownership and control are defensive. They reflect a desire to shield business from possible attacks by state institutions or private-sector rivals. Improvements in corporate governance, for example, would be easier to achieve if Russian firms did not believe that transparency was likely to render them more vulnerable to bureaucratic predation. Of course, there are other motives for opacity, such as tax evasion. Nevertheless, substantial improvements in corporate governance and private-sector behaviour are unlikely in the absence of similar improvements in the functioning of state institutions: state reform is a necessary, though by no means sufficient, condition for 'civilising' Russia's private-sector business practices.

\section{An effective anti-corruption strategy will of necessity be multi-faceted}

Shleifer and Vishny (1993) highlight an important difference between two basic forms of official corruption: one involves collusion between officials and private citizens at the expense of the state; the other involves the abuse of power by officials to extract rents from private agents. An official might, for example, be charged with allocating some sort of permit to those who meet specific criteria and/or pay a certain fee. The official could collude with private citizens and accept bribes in return for issuing permits to those who do not meet the criteria or do not pay the fee, or he might demand payment over and above that required by the law in return for issuing the permits to those otherwise entitled to them. ${ }^{96}$ In the former case, the citizen and the official work together to cheat the state; in the latter case, it is the citizen who is being cheated.

Different approaches are needed to combat these two forms of corruption. The best way to prevent the former is to make it as hard as possible to steal from the state; otherwise, detection will be difficult, because the citizens involved will not complain. This approach is reflected in efforts to tighten control over budgetary expenditure and to increase top-down monitoring of officials and executive bodies by organs like the Accounts Chamber. A free press able to rely on legal norms that favour the transparency of state bodies also has a key monitoring role to play. Where bureaucrats try to extract rents at the expense of the public rather than the state, the citizen and the official have a conflict of interest: in this instance, the best approach is to give citizens effective means to defend themselves against racketeering by officials. Here, little has yet been done, especially with respect to such well known problems as corruption on the part of the the militia (ordinary police), the traffic police, and such bodies as the fire and sanitation inspectorates. These problems are often ignored or even denied by the state institutions in question. Rooting out this latter form of corruption will depend crucially on the availability of effective institutions available to the victims of such corruption - ordinary citizens and entrepreneurs. These institutions must be both able and willing to discipline official; they might include not only the courts but also some regulatory bodies or ombudsmen.

Whatever the differences in emphasis between the strategies adopted for tackling these different forms of corruption, greater transparency, the elimination of unnecessary regulation and the simplification of administrative procedures will be critical to both. The 'de-bureaucratisation' legislation of 2001-02 in part reflected this approach: by simplifying regulations, it sought to eliminate opportunities for corruption as well as to reduce the burden of compliance on businesses. The de-bureaucratisation package also reflected

96. His ability to do so depends to some extent on whether or not other officials can issue the same permit to the citizen if he refuses. 
to some extent the need to find a way to reduce the bureaucratic burden on business even in the absence of a successful civil service reform. Apparently unable to change the interfering and often predatory behaviour of many 'street-level' bureaucrats, the government tried simply to take away some of their power. However, this strategy clearly has limits. Bureaucrats find ways to resist curbs on their authority and, given the need for an efficient, good quality public administration in Russia, de-regulation of this kind can be only a partial solution to the problem.

Of course, corruption is not by any means limited to the state. The suborning of officials by private agents is no less a problem than the abuse of power by officials for personal gain. Here, too, there is much more to be done in an effort to prevent, detect and punish corruption. In order to fulfil its international obligations, Russia still needs to bring its rules and regulations into line with international standards with respect to criminalising the giving of bribes to domestic or foreign public officials. ${ }^{97}$ 'Whistleblower' protection measures could also play a role, provided that enforcement was effective enough to assure public and private sector employees that they would be protected if they reported suspected bribery.

\section{Judicial reform is far from complete and much remains to be done to establish the rule of law}

With much of the basic legislative framework governing the judiciary now substantially improved, the major challenge in the field of judicial reform will be the struggle to rid the courts of corruption and political influence - the so-called 'shadow justice' that the president decried in his 2001 message to the Federal Assembly. The involvement of state prosecutors and the security organs in commercial and political disputes remains a problem, as does judicial corruption. While managerial surveys suggest that the arbitration courts command more respect than most state institutions, this is chiefly a reflection of the low esteem in which the latter are held. The courts are still widely regarded as susceptible to political or other outside pressure or inducements, and a considerable body of circumstantial evidence suggests that this perception is often accurate.

Some steps have been taken to strengthen judicial independence, including a new law on the status of judges, which raises judicial pay (in an effort to reduce corruption) and puts in place new mechanisms for punishing judicial malfeasance. ${ }^{98}$ However, effective, consistent implementation of such measures will be difficult. The federal centre has also sought to improve the financing of the entire judicial system, so as to reduce the dependence of judges on regional authorities. The creation in 2003-04 of a new tier of arbitration courts, the arbitration appeals courts, will potentially be of even greater significance. Each of these new courts encompasses a number of jurisdictions. Hitherto, appeals against arbitration court decisions have been heard in the court of first instance, often with the same judge presiding. By creating a higher-level tier of courts to hear first appeals, the authorities hope to enhance the chances for a fair hearing of appeals and to reduce further the ability of regional bosses to meddle in judicial decisionmaking. ${ }^{99}$ Other relatively straightforward steps that could be taken to curb judicial bias and corruption might include random assignment of cases to judges, rather than the existing system where cases are allocated based on caseload and specialisation of the judges, and the mandatory publication of all significant judicial decisions, including the legal reasoning underlying those decisions. The Supreme Arbitration Court, which publishes its own decisions, has indicated that it plans to extend this practice to its

97. See OECD (2004b:62); Russia has applied to accede to the OECD Convention Against Bribery of Foreign Public Officials in International Business Transactions and to become a full participant in the OECD Working Group on Bribery. Russia also signed the UN Convention against Corruption in 2003 and the Council of Europe's Criminal Law Convention on Corruption in 1999.

98. 'O statuse' (2001).

99. 'Ob arbitrazhnykh sudakh' (2003). 
appellate courts and, eventually, to courts of first instance. ${ }^{100}$ As of early 2005 , however, this practice could be described as patchy, at best: some local arbitration courts published selected decisions, while others appeared to publish none.

These are desirable steps, but it would be a mistake to think that the power of regional or municipal authorities is the major problem here. There is a more general need for effective arrangements to insulate the judiciary from political pressures emanating from any level of government, not least the federal authorities, as well as to reduce the scope for interference in judicial processes by private agents. As the socalled 'Yukos case' has demonstrated, the federal authorities are themselves inclined at times to use the law enforcement agencies and judicial proceedings to pursue essentially political objectives. The need to curb executive-branch interference in judicial decision-making also points to the complementarities between judicial reform and the broader reform of state institutions. Attempts to pursue the former in isolation from the latter - such as the judicial reform package of 2001 - have had limited impact, largely because the real relationship between the judiciary and the executive branch changed little as a result of the new legislation. Reducing the scope for executive-branch officials to intervene in judicial processes is arguably a sine qua non for preventing private parties from seeking to subvert the course of judicial proceedings. As long as it engages in such practices itself, the state will find it hard to curtail corruption in the judicial system or to prevent powerful private-sector interests from abusing judicial processes.

Establishing the rule of law will require more than reform of the judicial system. Upholding the rule of law requires a strong state, capable of rights and providing impartial rule adjudication and enforcement. However, a state strong enough to perform these functions may succumb to the temptation to act arbitrarily itself. The rule of law thus needs not only a strong state but also strong institutions capable of constraining that state and, in particular, of constraining its coercive capacities. ${ }^{101}$ However, Russia largely lacks effective coercion-constraining institutions. Indeed, while the Russian state has often - and rightly - been described as a 'weak state', its capacity for coercion has been better preserved than any capacity for effective regulation or service provision and is out of proportion to its other institutional capacities. The strongest political institutions in Russia tend to be those best equipped for coercive action, while the weakest tend to be those charged with regulating the state's exercise of its coercive power. This makes it exceptionally difficult for the state credibly to commit itself to rule-governed behaviour. The weakness of this commitment has been particularly evident in the political and legal campaign directed against the oil company Yukos since mid-2003, but the Yukos case is unique only in its scale and visibility. The security services, the prosecutors and the police remain highly politicised and have been deployed with disturbing frequency against businessmen in conflict with federal or regional authorities.

\section{Greater coherence is needed in the application of rules across all levels of government}

One of the major aims of policy since 2000 has been the reconstruction of Russia as a unified legal space. By the end of the 1990s, thousands of laws adopted by Russia's constituent provinces, territories and republics were in conflict with federal norms, as, indeed, were many provincial charters and republican constitutions. One estimate in 2000 was that up to 30 per cent of sub-national legal acts would need to be amended, if not abolished, in order to bring lower-level legislation into line with the 1993 constitution and federal statutes. Over the last four years, several thousand regional and local laws and normative acts have been eliminated or amended in order to rectify such problems, and the Justice Ministry has established a register of over 100,000 laws in an effort to monitor matters. Yet the impact of this formal tidying up of the legal order has been limited in practice. Business surveys suggests that, for both foreign and domestic companies, the far more serious problem remains the inconsistency with which laws and regulations are

\footnotetext{
100. Kommersant, 11 June 2003.

101. See, for example, Greif (2005).
} 
interpreted and applied, particularly by sub-national governments. The formal rules of the game have changed substantially, but the informal rules often seem to remain exceedingly complex, arbitrary and opaque.

\section{The state's role as a property owner needs further attention}

While the reform of the state's basic administrative, judicial and regulatory institutions must now be regarded as perhaps the critical reform priority, a focus on the role of the state also raises issues of state ownership and the governance of state-owned companies. The Russian state remains an extremely important player in the economy, not only through the provision of public goods and services but also via its ownership of substantial productive assets. In many cases, continued state ownership of productive assets creates conflicts of interest for the authorities (particularly where the state's role as regulator is in tension with its role as owner) and serves to distort competition. Moreover, there is considerable evidence to suggest that state-owned companies are generally less efficient than their privately owned rivals and that enterprise insiders in large state companies are able to extract significant rents for themselves. ${ }^{102}$ Russia's reform agenda thus includes questions concerning the extent of further privatisation, the creation of suitable governance arrangements for companies that remain in state ownership and the implementation of policies that prevent anti-competitive behaviour on the part of state or private firms.

The government has committed itself to a wide range of reforms in this area, including substantial further privatisation and an ambitious restructuring of the electricity sector. It has also expressed an intention to increase transparency and level the competitive playing field in sectors such as natural gas, where state-owned concerns will continue to play a dominant role. ${ }^{103}$ However, actual progress in recent years has generally been relatively slow, and there have recently been signs that the state is now inclined to extend its asset holdings in some key sectors rather than reduce them. Certainly, there has been a tendency for it to intervene more directly in industrial sectors that are regarded as 'strategic'.

\section{Further privatisation will help relieve the state of the burden of unwanted assets}

One reason for the state's ineffectiveness as a property owner is the presence on its books of thousands of more or less 'accidental' holdings - residual stakes in enterprises that the authorities, for various reasons, have never sold. Thus, the main aim of most privatisation sales in recent years has simply been to rid the state of the burden of managing large numbers of enterprises and shareholdings that it has no interest in keeping. This is proving rather difficult: in 2003, the authorities sold only 59 per cent of the 970 unitary enterprises slated for privatisation and 37 per cent of the planned 1,695 blocs of shares. Further adjustments to existing privatisation legislation may help to accelerate the process of selling off small, illiquid blocs of shares and the large numbers of small unitary enterprises which there is no reason to retain in the state sector. The main difficulty in selling state shares in joint-stock companies is that the vast majority of the state's remaining stakes are small, and it is difficult, given Russia's current standards of corporate governance, to sell small stakes in companies that already have effective owners. In 2003, for example, 67 per cent of the shareholdings put up for sale were stakes of 25 per cent or less of the companies' equity - in other words, they were not even 'blocking minorities' ${ }^{104}$ Only 8 per cent were majority stakes. The illiquidity of small stakes makes it difficult to auction them, even where the companies involved are relatively attractive. In 2003, 62 per cent of the auctions held to sell state shares did not in the end result in a sale.

102. For details, see Ahrend (2004b), pp. 9-10.

103. On the outlook for natural gas, see Ahrend and Tompson (2004a).

104. Russian law requires shareholder majorities of 75 per cent or more for certain types of decisions; a stake of 25 per cent plus one share is thus sufficient to give an investor veto power in some areas. 
Part of the problem is that the privatisation law that entered into force in 2002 makes it difficult to offer such shares for sale in other ways. The law was largely written to prevent the privatisation abuses seen in the 1990s and thus makes it difficult to sell any state assets cheaply. As a result, the cost of preparing a small, illiquid shareholding for sale according to the law can exceed the price it will fetch. This is not an insoluble problem. The government is now working on steps to streamline the disposal of such small stakes. This will have to be done with care, however, in order to ensure that the streamlined procedures are not abused. At the same time, the Ministry of Economic Development and Trade is pressing for better organisation of auctions, including better marketing and provision of information to potential buyers.

\section{Steps are needed to improve privatisation processes}

A new law on the privatisation of state and municipal property was adopted in 2001 and entered into force the following year. In an effort to reduce conflict among the different state bodies involved in privatisation policy, the new law allocates responsibility for different categories of privatisation to different levels of government. The list of strategic enterprises and categories of state assets excluded from privatisation is now left to the determination of the president, while the Federal Assembly shares responsibility for the possible privatisation of large state-controlled monopolies such as Gazprom, the electricity monopoly RAO UES and Russian Railways. Privatisations in this sphere require the enactment of separate laws. The privatisation of all other federal property falls within the competence of the government. The privatisation of municipal or regional property is handled by the corresponding level of sub-national government. The law also provides for a system of auctions and tenders in which all participants have, at least in principle, an equal chance of acquiring the assets up for sale. However, it does little to increase the transparency of privatisation processes or to ensure equity in the conduct of privatisation tenders. The practice of structuring privatisation requirements so as to favour specific bidders continues. Thus, recent privatisations, including the sale of the state's remaining stakes in Lukoil and Slavneft, continue to look like largely pre-arranged affairs.

\section{The governance of companies destined to remain in state ownership needs to be re-examined}

The much more serious issue concerns the state's holdings in a number of companies that the authorities consider to be strategically important and have no intention of privatising. Some of these strategic holdings are in the defence sector, while others are engaged in infrastructure provision or other activities characterised by a significant degree of natural monopoly. However, many operate in competitive, or potentially competitive, sectors, such as banking and the extraction of oil and natural gas. There is a need to clarify the boundary between the state and the private sector, especially where stateowned entities continue to combine commercial activity with what are effectively regulatory or social service functions. There is a strong presumption in favour of a shift to the private sector activities that are commercial and (actually or potentially) competitive, and that do not involve sensitive regulatory or public-service functions. There is likely to be scope both for further privatisation of state-owned assets, particularly in sectors like banking and electric power. Unfortunately, there has since 2003 been evidence of a shift in the other direction, towards expanding the state's role in 'strategic' sectors, such as oil. Given the track record of most large, state-owned companies in Russia, this is not encouraging. As Ahrend (2004b:8-10) shows, output and productivity have generally grown much faster in sectors that are relatively free of state ownership and interference. Moreover, in sectors like oil, where private and statecontrolled companies operate side by side, the former companies have consistently been much more efficient. The extension of state control over resource-exporting industries is thus likely to lead to less efficiency, more rent-seeking and slower growth in the very sectors that have been driving growth in recent years. 
With respect to the governance of state-owned companies, several priorities need to be borne in mind:

- State-owned entities engaged in commercial activities should not be charged simultaneously with the performance of regulatory functions. The most egregious examples of this phenomenon are RAO UES and OAO Gazprom, the monopolists dominating the electric power and natural gas sectors respectively. While reform of the power sector is now under way, there is little indication of any movement with respect to the gas sector.

- The governance of state-owned enterprises should be structured so as to minimise the scope for either using state-owned companies as instruments of economic and social policy or for granting them privileged regulatory treatment which could distort competition in the affected sectors (e.g. Gazprom, Vneshtorgbank). Ownership of commercial enterprises should, in particular, be separated from policy-making and regulatory functions - the CBR's control over Sberbank is particularly problematic in this respect. ${ }^{105}$ The fact that governance arrangements can probably never eliminate such conflicts of interest entirely constitutes a strong argument for privatisation, except where there are compelling reasons to keep assets in state ownership.

- State-owned companies should be held to the highest standards of corporate governance when it comes to such issues as transparency and the treatment of minority shareholders, two areas where some state-controlled entities in Russia have sometimes fallen short of the ideal.

\section{More needs to be done to curb the role of officials in the day-to-day activities of private firms}

Private business in Russia remains over-regulated. Private entrepreneurs continue to be subject to too many rules and procedures, many of which no longer serve any legitimate governmental purpose, if indeed they ever did. In general regulations and regulatory procedures are also more complicated than they need to be. Excessive red tape, however, is only part of the problem. Surveys of entrepreneurs show that businesspeople continue to face major problems as a result of the instability of the regulatory frameworks they confront and inconsistency in the interpretation and administration of regulations, particularly at local level. ${ }^{106}$ Altogether, this combination of excessive regulation, frequent rule changes and inconsistent application make it extraordinarily difficult for private businesses to be certain of remaining on the right side of the law, which makes for yet more risk and uncertainty arising in connection with the regulatory burden. Moreover, as is well known, such a situation leaves considerable discretion in the hands of officials dealing directly with businesses, and can thus create opportunities for corruption. The nature of the problem is well illustrated by a recent cross-national assessment of the business climate in 16 emerging market economies. Managerial surveys in these countries suggest that only two had lighter tax burdens than Russia's, but Russia ranked tenth in terms of the quality of tax administration, twelfth in terms of managerial time spent overcoming bureaucratic hurdles and last in terms of the proportion of enterprises reporting that they encounter official corruption. ${ }^{107}$ On the whole, small and medium businesses are most vulnerable to such pressures, as they are generally least well positioned to defend themselves. Overregulation of this sort thus constitutes a significant impediment to the development of the SME sector and thus, to some extent, to the diversification of economic activity into new endeavours.

Rectifying this state of affairs will not be easy. As noted above, the 'de-bureaucratisation' package did appear to bring about some improvement, but progress slowed over 2002-03, and there is considerable evidence to suggest that officials became increasingly creative in limiting the impact of the de-

105. See Tompson (1998) and Tompson (2004:7-8 and 23-24).

106. See, for example, OECD (2004c).

107. Data from the World Economic Forum; see Gurvich (2005). 
bureaucratisation measures. There is clearly scope to do more. Although the survey data for 2001-03 shows a steady improvement in entrepreneurs' overall assessment of the business environment, excessive documentation requirements remain high on their list of complaints and around half identify one or more regulatory problems (licensing, registration, inspections, etc) as either a 'very serious' problem or as one 'threatening the existence' of the firm. Licensing regimes, in particular, merit further consideration, especially in view of evidence that the cost of licences (in both time and money) has been rising sharply. When the bill reducing the number of economic activities subject to licensing requirements was making its passage through the government in 2001, individual ministries and departments fought hard to preserve their own licensing powers. The number of areas of economic activity subject to licensing more than tripled during the course of the bill's passage into law, despite the fact that many of the most obviously 'licensable' fields of activity were expressly excluded from its provisions altogether, including finance (banking, insurance and the operation of financial exchanges were all excluded), communications (including both terrestrial and satellite communications, as well as broadcasting), international transport, agriculture, natural resource-based industries, education, nuclear energy, arms production, foreign trade and the production of spirit and/or alcoholic beverages. Scores of activities continue to be subject to licences that would not be required in most developed market economies, and many of these licensing regimes should be scrapped.

It will take some effort to ensure that the abolition of licensing regimes is real and not merely formal: in some instances, the abolition of 'licences' has given rise to new systems of 'permissions' ('razresheniya'), which are neither authorised nor forbidden by law. Bureaucrats thus continue to regulate market entry even where it is clear that they are not supposed to. The crucial aim must be to establish - in practice and not merely on paper - that whatever is not forbidden is permitted and to protect open market entry. Where it is necessary to retain licensing regimes, they should be revised so as to increase transparency and limit official discretion. Many of the most lucrative activities in Russia rest on licensing regimes - including resource extraction, telecommunications and banking, to name but three. In such sectors, mere bureaucratic discretion can represent a deadly threat to a business - a threat that officials do appear to exploit from time to time. In this context, the new draft law on the subsoil, which envisages a shift from reliance on licensing and bureaucratic discretion to a regime based on civil law agreements, is to be welcomed. A further step would be to implement plans to remove the powers of the police and other officials (such as fire and sanitation inspectors) to close down businesses on their own authority will be an important further step. A bill approved by the cabinet for submission to the Federal Assembly would require such officials to apply to the courts if they wished to close down businesses for regulatory violations. Despite the well known weaknesses of the judicial system, this could significantly reduce small businesses' vulnerability to bureaucratic rent-seeking.

\section{Competition policy should play a stronger role}

Many sectors of the Russian economy are characterized by high levels of ownership concentration. This concentration may not interfere with competition in truly internationalised sectors, provided that markets remain open to international competition. Indeed, in sectors like oil and metals, where the international players are very large, industrial consolidation may well be desirable. But these same levels of concentration can cause problems in domestic markets, including facilitation of collusive behaviour and provision of opportunities for abuses of market power to prevent new entry or growth of competing firms. The effects of such behaviours, including lowered efficiency, slowed growth rates and higher costs for both consumers and producers, can be substantial. Moreover, Russian markets are often less open than they appear, owing to informal barriers, particularly between regions. Even in relatively open tradables sectors, large and powerful domestic companies are capable of exercising significant market power, particularly in regional markets. Competition law has been weak in its provisions on these types of anticompetitive conduct, and the competition authority's attention diluted by too many tasks. As the government concentrates efforts on stimulating a more broadly-based economic growth, more effective prevention of 
anti-competitive behaviour will be vital. The competition authority should be strengthened, and stiffer penalties should be set for anti-competitive behaviour.

The role of competition policy will be particularly important in the non-tradables sectors, where the discipline of competition from foreign imports is, by definition, absent. The fact that several important non-tradables sectors in Russia are largely monopolised, state-controlled and subject to restrictions on foreign entry merely reinforces these concerns. Given the Russian authorities' concern with industrial competitiveness and economic diversification, it is crucial to note that the competitiveness of tradables sectors is directly affected by the competitiveness of non-tradables, ${ }^{108}$ and this, in turn, depends in no small measure on the degree of competition in non-tradables. This is not, however, solely an issue for competition policy: structural reform of major infrastructure sectors is also necessary, not least because the current configurations of the gas and electricity sectors, in particular, can make it extremely difficult to identify anti-competitive behaviour and take action in a timely fashion. ${ }^{109}$ While reform of the power sector is now under way, there has been little sign of any readiness to restructure the gas sector or even to reassess the role currently played by Gazprom, which combines commercial and regulatory functions in a highly untransparent fashion. This has constituted a significant impediment to the development of the sector in recent years. At the same time, the competitiveness of Russian tradables sectors would also be enhanced by the elimination of many of the administrative barriers erected by regional and local authorities, which are particularly prone to intervene in such sectors as fuel and energy, passenger and freight transport, and communications, generally in ways that serve to stifle competition in an effort to protect local markets.

\section{There are complementarities between stronger competition policy and better corporate governance}

Although the connection between corporate governance and competition policy is not intuitively obvious, further efforts to improve the former will also serve to strengthen the latter. The effectiveness of the competition authority's efforts to monitor M\&A activity, to investigate collusion or to deal with possible abuses of market power depend in no small measure on transparency of ownership. The use of a number of formally independent legal entities to conceal beneficial ownership or to obscure relationships among parties is most often employed to shield the company from possible state predation, to evade taxes or to conceal the nature of related-party transactions. However, such stratagems can also be used to circumvent competition law. Even where the identities of the true owners are well known, proving the relationships involved can be difficult. Russia is by no means the only economy in which a wide range of screening devices are sometimes employed in order to conceal beneficial ownership, but these practices are so pervasive in Russia as to constitute a real problem for the competition authority - as well as for state bodies involved in the conduct of tenders (especially privatisation tenders) or granting licences. There is much still to be done here: Russian law still lacks a clear, explicit definition of beneficial ownership, while attempts to regulate the activities of related parties are handicapped by the fact that the definition provided in the law on joint-stock companies is both narrow and ambiguous. ${ }^{110}$ Full disclosure of beneficial ownership and stricter controls on related party transactions would thus serve to improve the protection of shareholders' rights - the primary aim of such reforms - and also to strengthen competition policy. Here, as in so many other fields, reforms in seemingly distinct spheres are in fact closely related and indeed complementary.

108. The competitiveness of tradables sectors is affected by the prices paid for land, service, utilities and other non-tradables.

109. For details, see Pittman (2001) and OECD (2004a:146-51, 155-61, 191-2).

110. See OECD (2004c), pp. 3-6 for details on these two points. 


\section{Many sectors would benefit from a relaxation of restrictions on foreign investment}

As noted above, the law on foreign investment now extends national treatment to foreign investors in most respects. However, numerous formal and informal barriers to foreign investment remain, including sector-specific limits on foreign ownership in some sectors, permit procedures that apply only to nonresidents and regulations governing the employment of foreign personnel in foreign-owned firms. These serve little purpose other than to protect incumbents in the sectors affected - usually domestic producers, but sometimes also foreign firms that had established themselves in the market before the regulations were adopted. These restrictions tend to depress overall levels of foreign investment and may also skew somewhat its sectoral distribution. Among the formal restrictions that should be relaxed, if not eliminated altogether, are limits on foreign activities in the financial sector (see below) and agriculture, as well as in such industries as aviation, land transport, telecommunications and media. ${ }^{111}$ It is striking that many of these sectors, not least agriculture and aviation, are in dire need of investment. Other restrictions are general, rather than sector-specific, such as the 1999 law on government procurement, which limits foreign participation in tenders. ${ }^{12}$ However, the main barriers facing non-residents are probably not formal legislative restrictions such as these but rather the overall complexity of regulation in Russia and the inconsistency and unpredictability with which much of it is applied at all levels of government. Given the often bewilderingly complex bodies of formal rules on the books and the lack of transparency of most state institutions, there is all too often a significant gap between the formal and informal rules of the game. Reliance on unwritten rules, of course, tends in almost any situation to favour insiders and to handicap outsiders in general and foreigners in particular. This reliance on informal norms and unwritten rules also tends to foster corruption.

There has also been much discussion recently of including potentially severe restrictions on foreign participation in the development of natural resource deposits in the new law on the subsoil now being prepared. This could have a particularly significant impact on foreign investment in the oil industry, hitherto the sector of greatest interest to foreign investors. The draft submitted to the government in December 2004 would authorise the government to limit access to auctions for any firm with a foreign partner on national security grounds. While this would represent no change from the status quo, the text does not specify in any detail how it might be applied. In principle, it could be applied to any company with a foreign shareholding, exempting very few from the restrictions. However, such a radical interpretation of the provision is highly improbable; its more likely effect would be to provide the authorities with a legal basis for determining in somewhat ad hoc fashion which companies would and would not be allowed to participate in competitions for exploration and production rights. Finally, it should be noted that some regulations that apply in principle to all companies are more likely to affect foreign investors; the remaining currency controls are a case in point.

Yet while relaxing informal and formal discrimination against non-residents will be important in attracting investment, sustained growth in FDI will, in fact, depend on many of the same factors as investment growth more generally. The main restraints on FDI are not so much direct formal restrictions as problems with the institutional environment that affect domestic and foreign businesses. These include high barriers to entry in many sectors, the weakness of the judicial system and extensive bureaucratic interference in - and often predation on - private businesses. While these often affect foreigners more than domestic actors, addressing them will provide important benefits to foreign and local investors alike.

111. See OECD (2004b:77-9) for details.

112. Discrimination in government procurements is not limited to foreigners; regional and local authorities also tend to discriminate in many cases against Russian companies based outside their jurisdictions. 


\section{Steps are needed to reform sectors dominated by state-controlled monopolies}

Natural gas, electricity, rail transport and banking are four areas in which structural reforms are of tremendous importance. The essentially infrastructural character of all four sectors means that improvements in the efficiency of each could have potentially enormous knock-on effects for other industrial and service sectors. For the same reason, failure to reform them is likely to impede not only their development but the growth of the economy as a whole. To date, the authorities have launched major reforms in the latter three sectors, with rail reform being the furthest advanced at present, while there has been almost no progress in reforming the gas industry, arguably Russia's least reformed major sector and undoubtedly one of its least efficient. ${ }^{113}$ The four sectors differ in many important respects, and there is certainly no single model of reform applicable to all, but there are a few common challenges worth highlighting. ${ }^{114}$

- In each case, one of the major aims of reform is to make resource allocation more efficient - in the banking sector, by fostering the development of efficient financial intermediation and in the rail, power and gas sectors by putting an end to the provision of implicit subsidies and crosssubsidies via tariffs which are below long-run cost-recovery levels. Such subsidies are valuedestroying and distort resource allocation and investment incentives.

- All four sectors will require a fair degree of regulation even after reform. This makes issues pertaining to the competence and probity of state institutions particularly relevant, as well as questions relating to the capacity of the state to create strong, independent regulators and to produce high-quality regulation.

- The state is extensively involved in all four sectors, not only as a regulator but also as the owner of the monopolists that dominate each. In all four cases, the state's management of the monopolists is characterised by a basic tension between the desire to make the monopolists more efficient and the habit of imposing unprofitable social obligations on them - obligations that are often 'compensated' via fiscal or regulatory privileges.

- This, in turn, points to the desirability of separating regulatory and ownership functions more clearly and of reducing the state's ownership of banking, rail and energy sector assets. This has been a major element of rail reform, but the overlap between the two functions continues to be particularly marked in the gas sector.

- In each of the sectors, the state-controlled monopolies act at times in ways that distort or simply suppress competition. It is no accident that they are among the entities most often in conflict with the competition authority. However, attempts to challenge such behaviour have generally been unsuccessful, owing to the weakness of the competition authority and of the general framework of competition law and policy in Russia.

- A further argument for reducing the state's ownership role in these sectors stems from evidence suggesting that insider managers in the major state monopolies have often been able to divert cash flows from them and to engage in what is euphemistically described as 'informal profitseeking' (i.e. rent extraction) at the expense of the state. In some cases, state assets have been

113. See Ahrend (2004b) and Ahrend and Tompson (2004a).

114. For detailed analyses of natural gas, electricity and banking, see OECD (2004a); on electricity, see also IEA (2005). On rail reform, see ECMT (2004). 
alienated to persons or entities affiliated with insider managers; in other instances, cash flows are diverted or concessionary terms are offered to related private entities.

- In each instance, questions of transparency are central to reform. While recent years have seen some progress with respect to increasing the transparency of Sberbank, Gazprom, RAO EES and the railways, there is still more than can and should be to done to enhance the transparency both of the companies involved and of the policy-making and regulatory processes. Nowhere is this more evident than in the gas sector. Gazprom stands out, even in the context of Russia's highly secretive corporate culture, for its exceptional opacity - an opacity which is more pronounced in its performance of various quasi-sovereign functions as in its commercial affairs. ${ }^{115}$

The reform of Russia's state-controlled monopolies thus is a multifaceted process, in which a number of the specific reform challenges outlined above come together. While this makes monopolies reform a particularly difficult test, it also suggests that there could be significant spill-over effects, in terms of establishing precedents and building state capacities, from successful reforms in these sectors.

\section{The authorities need to tackle gas-sector reform}

As noted above, Russia has undertaken a major overhaul of its railways sector and has also embarked on the restructuring of its power sector. ${ }^{116}$ The reform of Russia's crucial and highly monopolised gas sector, however, has repeatedly been postponed, and it is not clear that any substantial reform will be undertaken in the foreseeable future. Despite its enormous importance, the natural gas industry is perhaps the least reformed major sector in Russia. Both the up- and down-stream sectors are dominated by a statecontrolled, vertically integrated monopolist, OAO Gazprom. Though organised as a joint-stock company, Gazprom in some respects operates as an arm of the state. It combines commercial and regulatory functions, and maintains tight control over the sector's infrastructure and over information flows within it. Gazprom's control over information is particularly problematic, as it renders opaque much of what happens in the sector. Underlying all of this regulation and rationing is the unsustainable under-pricing of natural gas, which constitutes a subsidy from the gas sector to the rest of the economy. Most gas continues to be sold at regulated prices that are below full cost-recovery levels, although regulated tariffs for all consumers except households are now rapidly approaching cost-recovery levels. While gas tariffs have risen rapidly since 2000 , outpacing both consumer- and producer-price inflation, they still have some way to go to reach long-term sustainable levels.

The inefficiencies inherent in the sector's architecture would, on their own, constitute compelling arguments for reform: an economy as dependent on its resource sectors as Russia's can ill afford such inefficiencies in what is arguably its most important resource industry. However, the case for reform is even more compelling in view of the need to raise investment and output very substantially over the coming years in order to meet rising domestic demand and growing export commitments. The natural gas sector as it is currently constituted is highly unlikely to be able to sustain sufficient output growth to satisfy internal and external demand over the long term. Given that the importance of gas extraction and exports to Russian growth is likely to grow over the medium term, this is a particularly serious concern. Both Gazprom and the government acknowledge that non-Gazprom production must grow rapidly if the gas industry is to develop successfully, but Gazprom's current position within the sector constitutes a significant impediment to such growth, restricting both small producers' access to the market and consumers' freedom to choose their suppliers. There is significant potential for accelerating the growth of non-Gazprom production and making gas supply in Russia more competitive. This potential cannot be

115. See Ahrend and Tompson (2004a).

116. For detailed analyses of these two reforms, see IEA (2005) and ECMT (2004). 
realised until Gazprom's domestic rivals can be assured of equal treatment, which is impossible as long as Gazprom controls both the information flows and the infrastructure. Certainly, Gazprom has no incentive to exclude them from the market altogether; indeed, it wishes to see their role in supplying domestic consumers increase. However, Gazprom's position gives it considerable scope to ensure that the smaller producers market their gas on terms that suit Gazprom: the monopolist can discriminate against other producers and it has incentives to do so. The establishment of an effective regulated third-party access regime for the sector's infrastructure is likely to be absolutely crucial to the outlook for investment by nonGazprom producers.

There is thus an immediate need to increase transparency in the sector and also to transfer what are essentially regulatory functions from Gazprom to the state. Over the medium-to-long term, Gazprom's natural monopoly/infrastructure provision functions should be separated from its potentially competitive activities. In particular, this will necessitate unbundling Gazprom's transport and dispatch operations into separate entities. This will be a long and complex process, which should not be executed in haste; it is therefore important that restructuring be planned and started soon. Finally, tariff policy needs to be both more transparent and more consistent. The government is committed to raising tariffs to cost-recovery levels and has made considerable progress in doing so already. However, it is understandably reluctant to risk lower growth and higher inflation by raising tariffs too rapidly. A big-bang approach would hit households and industry extremely hard. Both need time to adjust. However, the need for a more gradual approach makes it all the more important that the authorities commit credibly to a price path for regulated tariffs and to clear, transparent methodologies for calculating them. This would, inter alia, make it easier to introduce longer-term contracts into the sector. At present, tariffs are adjusted once or even twice a year, and the increases often look somewhat ad hoc, the product of bargaining between the government and Gazprom. Various drafts of the government's energy strategy and other official documents have outlined medium-term targets for gas prices, but price increases to date have consistently been smaller than these targets would imply. The targets for gas price increases reportedly included in the May 2004 agreement with the EU on WTO entry should therefore be seen as an important step forward, for they represent a binding commitment undertaken by the government in an international agreement. At the same time, the authorities should consider ways of ensuring that the state captures a larger share of the rents resulting from current very high gas prices, or at least that these rents are directed towards the development of the gas sector. Gazprom has recently shown a tendency to use these rents to acquire all manner of assets, many of them unrelated to its core functions.

The absence of real progress on gas-sector reform must surely be counted one of the government's major policy failures of recent years. Many structural reforms are politically difficult to implement precisely because they involve large up-front costs, while the benefits of reform will be realised only over the long term. Certainly, any fundamental restructuring of the gas sector would be a complex, and lengthy process. However, there are a number of relatively modest steps that could be taken rather quickly and that would begin to pay tremendous dividends at an early stage. The establishment of effective, regulated thirdparty access to the trunk pipeline network and some access to export markets for non-Gazprom producers would give a tremendous boost to the industry. Once assured that they would be able to enter the market on fair terms, non-Gazprom producers could increase investment and output very rapidly indeed. At present, however, they remain constrained by the authorities' failure to break Gazprom's stranglehold on the industry. Non-reform in the gas sector also risks distorting the on-going reform of the electricity sector, as well as attempts to press ahead with reform of the municipal utilities. ${ }^{117}$

117. See Ahrend and Tompson (2004a). 


\section{Better regulation of the financial sector will help foster the development of real financial intermediation}

The extent to which the various segments of the financial sector come to perform the roles expected of them - and, in particular, the extent to which they develop as effective mechanisms for the mobilisation and intermediation of savings and the management of risks - will depend to a great extent on the vigorous implementation of a range of regulatory reforms now in the works, as well as on wider economic developments. All the major financial sectors have been under-regulated, although they have often been subjected to quite onerous reporting requirements and other red tape. The banking sector best exemplifies this problem: only in the last few years has there been a consistent drive to privilege substance over form in regulating the sector. The challenge for reform in the other two sectors is similar: first, to reduce the burden of red tape and the proliferation of highly formalistic regulatory requirements, which are costly for market actors but achieve little; and, secondly, to establish effective regulatory systems that are stable, transparent and focused on substance rather than form. These tasks are explored in greater detail below.

\section{Banking reform will test both the political will and the regulatory capacities of the authorities}

After years of delay, the pace of banking reform accelerated markedly in early 2002. The most important reform initiatives of the last two years have included deposit insurance legislation, a major reform of the framework for prudential supervision, steps to increase transparency in the sector, and measures to facilitate the development of specific banking activities. Each of these measures is an important step in its own right. Even more important is the 'fit' between them: the various strands of reform complement each other well, which reflects the coherence of the CBR's overall strategy. The emphasis on transparency, in particular, is especially welcome, as greater openness will facilitate better monitoring of banks by private-sector agents. The real test of this banking reform strategy, however, will be in implementation. The reforms challenge numerous vested interests and their successful realisation will require considerable political will as well as the development of regulatory capacities of a very high order. In this connection, it must be observed that the authorities' handling of turbulence in the banking sector during May-July 2004 revived doubt about their ability and willingness to press ahead with difficult reforms. The CBR was slow to react to the crisis as it developed, and when it finally did take action, some of its decisions were difficult to reconcile with its stated policies. ${ }^{118}$ However, of greatest concern were the mixed signals emerging from the Kremlin and the government, which suggested that the authorities were not united in their approach to banking reform and raised questions about whether the CBR really could count on the political and administrative support needed to press ahead with its planned reforms. The success of banking reform will also depend in no small measure on other institutional improvements, many of them not directly related to banking. A large and growing body of empirical research emphasises that the success of deposit insurance and of systems of prudential supervision are closely related to the overall institutional environment and to the rule of law in particular. ${ }^{119}$ This suggests yet another set of 'complementarities' among different structural reform policies.

\section{More needs to be done to reduce the state's role in the provision of banking services}

There is also a need for a clearer government strategy with respect to the future of state-owned banks; at present, Russia's largest banks continue to be controlled by the state, while regional authorities continue to intervene, sometimes quite heavy-handedly, in local banking sectors, suppressing competition and impeding entry. There are good reasons for seeing the state's continuing dominance of the banking system as a problem. State ownership and state intervention in credit allocation tend to distort competition, to

118. The extension of a loan to state-owned VTB, enabling it to buy a threatened but still viable Guta-Bank, stands out as a particularly troubling precedent, as did the apparent attempt to use Sberbank as a lender of last resort on the inter-bank market.

119. For details, see Tompson (2003). 
aggravate moral hazard by encouraging the expectation of a bailout, and to undermine the efficiency of intermediation, as banks often pursue policies that reflect the non-commercial requirements of the authorities rather than good commercial sense. The short history of Russia's banking sector exemplifies many of these problems, particularly with respect to competition and the imposition of hard budget constraints on banks. Official policy is that state-owned banks should exist, if at all, to correct market failures: their activities should be specialised in sectoral and other niches which the market will not address on its own. In practice, however, the major state-owned banks in Russia have tended to operate as universal banks, with Sberbank, in particular, exploiting its protected retail monopoly to extend its business in other directions. It is now the dominant bank in a number of market segments, not only retail. Vneshtorgbank, too, has become increasingly aggressive in its drive to expand, at times with the apparent support of the regulatory authorities for steps that contradict stated policies toward the sector.

The Russian authorities have long been committed in principle to reducing both state ownership of commercial banks and the intervention of state institutions in credit allocation. However, progress has been slow. The government and the Bank of Russia should undoubtedly proceed cautiously in considering any major changes to the status of Sberbank or other very large state-owned banks, but the status quo is undoubtedly problematic from the point of view of banking sector development. While a more fundamental restructuring, involving privatisation of most of the state's banking assets, is likely to prove desirable over the long term, the more urgent priority must be to reduce the distortions caused by the state's current position in the sector and to facilitate the growth and consolidation of private banks capable of competing with Sberbank and other state-owned banks. These might include steps to simplify mergers and acquisitions, and also to facilitate easier branching, as well as the rigorous application of prudential norms to state-owned banks. Above all, the authorities should consider changes to the governance structure of the main state-owned banks that would make possible a credible commitment by the government and the central bank neither to extend special privileges to them nor to intervene in their commercial affairs. Addressing the problems posed by state-owned banks will be crucial to tackling the more general problem of promoting competition in the banking sector, which is still relatively weak. This is particularly important in view of recent empirical research suggesting that greater competition in banking allows financially dependent industries to grow faster. ${ }^{120}$

\section{Financial markets need better sector-specific regulation and better framework conditions}

Russian financial markets are also under-governed, a matter of particular concern in view of their rapid growth. Gaps in Russian legislation exist in a number of key areas. Work has begun on new bills to deal with insider trading and market manipulation, but they could take some time to adopt, as the courts' lack of experience in handling such issues means that the language of the new statutes must be drafted with exceptional care. The relatively short list of permitted securities set out in Russian statute is considered to be exhaustive: no one can create new forms of securities without legislation. There is a need to make the existing securities laws more open to financial innovation and in particular to provide a stronger legal basis for such activities as mortgage finance and asset securitisation. There is still no proper legislation governing derivatives either. Small markets in instruments such as options and futures exist, but their legal position is uncertain. ${ }^{21}$ There is also uncertainty over the practice of close-out netting, whereby all transactions of a given type are netted at market value in the event of one party's bankruptcy. Such debt off-sets are not permitted in the event of bankruptcy in Russia, which greatly increases the risk for derivatives providers. The authorities are well aware of the problems listed above and, in many cases, are actively working on measures to address them. Hitherto, conflicts among competing regulatory authorities have bedevilled attempts to develop the non-bank financial sector. It is to be hoped that the creation of the

120. See Claessens and Laeven (2005).

121. In the late 1990s, a Russian court found that derivatives contracts fell under the Civil Code provisions pertaining to wagers and so were not subject to enforcement by the courts. 
new Federal Securities Market Agency will lead to an acceleration of reform and greater coherence in the regulation of different market segments.

The development of financial markets, like that of the banking sector, is in many ways constrained by problems with the larger contracting environment. The weakness of the rule of law is a particular problem here. Securities markets are markets in legal claims and obligations. They are only as good as the legal system supporting them. Also important are corporate governance issues, including ownership transparency and the extent and quality of disclosure. The desire to raise new capital on securities markets or to increase market capitalisation is, of course, a major incentive to improved disclosure and governance. For successful borrowers, the bond markets, in particular, offer unsecured credit for longer terms than would be available from banks. At the same time, poor corporate governance and lack of disclosure make it more difficult to police securities markets. Finally, corruption and rent-seeking on the part of officials can undermine the effectiveness of even the most enlightened regulatory framework, since the administration of the rules is as crucial for market participants as their content.

\section{The financial sector would also benefit from the removal of the remaining barriers to foreign entry}

Russia stands to gain considerable benefits from greater foreign participation in its financial sector, even though there are strong protectionist pressures within the banking and insurance sectors, in particular. While Russia does not necessarily need or want a financial sector dominated by foreign players, it does need a higher level of foreign involvement in both banking and insurance, if only to reap the benefits foreign banks can bring to the sector in terms of skills, technology and credibility. It would therefore be in Russia's interests to eliminate the remaining restrictions on foreign entry into these sectors - something Russia is likely to have to do in any case as part of its WTO accession process. While there is no longer any limit on the foreign capital share in the Russian banking system, ${ }^{122}$ a number of lesser restrictions on foreign involvement remain, including the requirement that the CBR approve any acquisition of shares in a Russian bank by non-residents. However, the CBR is pressing for changes that would subject foreign investors to the same percentage thresholds as domestic investors when it comes to requiring prior approval for share acquisitions. There are also other regulations, such as those governing the appointment of foreigners as top managers or board members of Russian banks, which depend to a great extent upon the judgements of the CBR. ${ }^{123}$

Formal barriers to foreign entry are far more extensive in the insurance sector and include a 25 per cent ceiling on the foreign capital share in the sector. ${ }^{124}$ EU-based insurers enjoy a better position than other foreign insurance companies, because many of the restrictions on foreign activities do not apply to the former under Russia's Partnership and Cooperation Agreement with the European Union. EU insurers have recently gained the right to engage in the provision of all types of insurance, including life insurance and mandatory insurances, such as motor insurance. Subsidiaries of foreign insurance companies from outside the EU and Russian insurance companies that are more than $49 \%$-owned by non-EU foreign

122. In any case, the ceiling had never actually had legal force nor had foreign banks come close to breaching it. At the beginning of 2004, non-residents owned stakes in only 128 Russian credit institutions, of which 32 were wholly foreign-owned.

123. See OECD (2004b: 71-3) for further detail on these and other restrictions. There has been pressure from the banking lobby to establish a 25 per cent ceiling on the foreign capital share, but the authorities have so far resisted such proposals, which run counter to their overall policy of seeking to encourage greater foreign participation in the sector.

124. This ceiling was raised from 15 per cent under legislation adopted in December 2003. In fact, the finance ministry estimated the foreign capital share at just 2.7 per cent as of 1 January 2004, so this matters little at present. 
entities or individuals are excluded from the provision of compulsory insurances or life insurance. ${ }^{125}$ There are also special regulations concerning the role of foreign citizens in managing insurance companies and governing the sale of shares in Russian insurance companies to non-residents or increases in the charter capital of insurance companies paid from outside the Russian Federation.

\section{Conclusion}

The foregoing discussion has addressed a wide range of disparate and often rather technical issues. However, the analysis also returns again and again to a small number of fundamental questions. This is neither accidental nor the product of needless repetition. It reflects the two key lessons that emerge from this overview of structural reform in Russia.

The first concerns the need to continue working to establish sound, basic institutions and framework conditions for the market economy. Neither the revision of formal laws and regulations nor the pursuit of technically complex reforms of key sectors like rail transport, power or pensions can do much to foster economic growth and development in the absence of a major improvement in the way the Russian state itself functions. Considerable priority must still be attached to such basic issues as strengthening the rule of law and the security of property rights, increasing the transparency and accountability of state institutions, and combating corruption. There is still more to be done to curtail the state's propensity to rely on direct intervention and control over assets and markets rather than on impartial regulation, and to create a state administration that is able - and willing - to perform the role required of it in a well functioning market economy. The core of that role is the provision of the public goods that private agents need in order to invest, produce and transact efficiently. Many of these goods - like the rule of law - are not even 'economic' in the narrow sense of the word. ${ }^{126}$ However, they are crucial to Russia's long-term economic future.

The second theme that runs through the analysis above is the need to pursue reforms across a broad front, in order to realise the complementarities that exist among various reforms, many of which have been noted above. This is a critical point: while policy coherence, the term most frequently employed by international organisations, is often viewed as a political constraint, policy complementarity signals the possibility of realising the additional benefits that may stem from pursuing different strands of reform together. Policy complementarities arise when the returns generated by two or more reforms in tandem exceed the sum of those that would be realised if they were each pursued separately. ${ }^{127}$ The potential benefits arising from complementarities among different strands of reform underscore the importance of formulating an explicit, coherent, long-term reform strategy, adopted at the highest levels of government, to integrate the various reform efforts now underway.

Consideration of these two themes helps clarify a final, crucial question facing the Russian authorities: the relative priority of different reforms. As is clear from the foregoing analysis, there is an enormous amount to do, and it would be both unrealistic and unfair to believe that any government could do it all at once. However, the emphasis on reform complementarities and on shoring up the basic institutions of the market economy suggests two lines of policy that might be considered the top priorities:

125. Allianz and AIG were in the life insurance business in Russia before this legislation was adopted in 1993 and so were exempt from this restriction even before the EU-Russia agreement relaxed the rules governing EU insurers operating in Russia.

126. Most are concerned in one way or another with the formulation, implementation and enforcement of rules and regulations. Frameworks of laws and rules are best viewed as abstract public goods. To the extent that they are consistently and impartially applied, they are 'jointly consumed': both rivalry and excludability are low. If they are effectively enforced, then exit is low as well.

127. See Braga de Macedo and Oliveira Martins (2005). 
- 'State reform' in a broad sense (i.e. judicial and administrative reform). The knock-on effects generated by real steps to strengthen the independence and probity of the judiciary and by even a moderately successful reform of the civil service would be tremendous. Prospects for the successful implementation of virtually every other major structural reform would be improved, while the reduction in official corruption and rent-seeking would of itself represent a major improvement in the business climate.

- Further reductions in barriers to entrepreneurship. This second priority is very closely related to the first, since many of the barriers in question stem not from formal regulation of new businesses but from informal - and often corrupt - practices on the part of officials. The potential complementarities between the two reforms are clear: further reductions in de jure and de facto licensing and other regulatory burdens would reduce bureaucrats' opportunities to intervene in the affairs of private businesses, while judicial and civil service reforms would improve the fairness, transparency and efficiency with which the remaining regulations were administered.

To judge from their programmatic statements, the Russian authorities understand, and are committed to, these priorities. Recent years have seen important steps towards realising them. However, the actions of state bodies often contradict stated reform goals, and there has also been considerable evidence of a drift towards more interventionist, less rule-governed - and sometimes predatory - state behaviour. Russia's long-term growth depends in no small measure on checking such tendencies and reinvigorating those lines of reform that aim at creating not merely a strong state, but one which is law-based, accountable and efficient. 


\section{BIBLIOGRAPHY}

Ahrend, R. (2002), "Press Freedom, Human Capital and Corruption”, DELTA Working Paper 2002-11, February.

Ahrend, R. (2004a), 'Accounting for Russia's Post-Crisis Growth', OECD Economics Department Working Paper No. 404, September.

Ahrend, R. (2004b), 'Russian Industrial Restructuring: Trends in Productivity, Competitiveness and Comparative Advantage', OECD Economics Department Working Paper No.408, September.

Ahrend, R. and J. Oliveira Martins (2003), "Creative Destruction or Destructive Perpetuation: The Role of Large State-owned Enterprises and SMEs in Romania During Transition", Post-Communist Economies 15:3, September.

Ahrend, R. and W. Tompson (2004a), "Russia's Gas Sector: The Endless Wait for Reform?" OECD Economics Department Working Paper No. 402, September.

Ahrend, R. and W. Tompson (2004b), "Oil Sector a Drag on Economic Growth”, Moscow Times, 3 December.

Alexeev, M. (1999), "The Effect of Privatization on Wealth Distribution in Russia”, Economics of Transition 7:2, July.

Angelucci, M., A. Bevan, S. Estrin, J. Fennema, B. Kuznetsov, G. Mangiarotti and M. Schaffer (2002), "The Determinants of Privatised Enterprise Performance in Russia", London: CEPR Discussion Paper No. 3193, February.

APK (2002), Federal’nyi zakon RF ot 24.07.2002 № 95-FZ “Arbitrazhnyi protsessual’nyi kodeks Rossiiskoi Federatsii”.

Arkhangel'skaya, N. (2003), "Reforma gossluzhby: Stekliannyi potolok”, Ekspert, 3 March.

Barberis, N., M. Boycko, A. Shleifer and N. Tsukanova (1995), "How Does Privatisation Work? Evidence from the Russian Shops", NBER Working Paper 5136, May.

Bessonova, E., K. Kozlov and K. Yudaeva (2003), "Trade Liberalisation, Foreign Direct Investment and Productivity of Russian Firms", Moscow: CEFIR, September.

Blasi, J., M. Kroumova, and D. Kruse (1996), Kremlin Capitalism: Privatizing the Russian Economy (Ithaca: Cornell University Press).

Boone, P. and D. Rodionov (2002), “Sustaining Growth", Brunswick USB Warburg Russia Equity Research, September. 


\section{ECO/WKP(2005)17}

Berglof, E. and P. Bolton (2001), “The Great Divide and Beyond: Financial Architecture in Transition", William Davidson Working Paper 414, December.

Braga de Macedo, Jorge and Joaquim Oliveira Martins (2005), "Policy Complementarity and the Design of Reforms" (Unpublished paper: Fondation Nationale des Sciences Politiques, Paris, 2005).

Brunetti, A. and B. Weder (2003), “A Free Press is Bad News for Corruption”, Journal of Public Economics 87:1801-24.

Brym, R. and V. Gimpel'son (2004), "The Size, Composition and Dynamics of the Russian State Bureaucracy in the 1990s", Slavic Review 631:1, Spring.

Claessens, C. and S. Djankov (2002), "Privatization Benefits in Eastern Europe", Journal of Public Economics 83:3, 307-324.

Claessens, C. and Laeven, L. (2005), 'Financial Dependence, Banking Sector Competition and Economic Growth', World Bank Policy Research Working Paper 3481 (January).

Demirgüç-Kunt, A. and V. Maksimovic (1998), "Law, Finance and Firm Growth", Journal of Finance, 53:6, December.

Drebentsov, V. (2004), “Diversifying Russia”, Mimeo: World Bank Moscow Office, February.

Dynkin, A. A. (2004), Integrated Business Groups in the Russian Economy, Moscow: PSI Foundation, January.

EBRD (2003), Transition Report 2003: Integration and Regional Cooperation, London, October.

ECMT (2004), Regulatory Reform of Railways in Russia (Paris: European Committee of Ministers of Transport).

Ericson, R. (1995), “The Russian Economy since Independence”, in Gail W. Lapidus (ed.), The New Russia: Troubled Transformation, Westview Press, Boulder.

Ericson, R. (1998), "Economics and the Russian Transition”, Slavic Review 57:3 (Fall).

Ernst, M., M. Alexeev and P. Marer (1995), Transforming the Core: Restructuring Industrial Enterprises in Russia and Central Europe (Boulder, CO, Westview Press).

Gavrilenkov, E. and V. Koen (1994), "How Large was the Output Collapse in Russia? Alternative Estimates and Welfare Implications", IMF Working Paper 94/154 (Washington: International Monetary Fund).

Gavrilenkov, E. and E. Yasin (2005), "Russia: Current Macroeconomic Situation and Economic Growth Outlook", presentation made to the OECD Economics Department Seminar "Sustaining Long-Term Growth in Russia: Possible Development Paths", Paris, 24 January.

Gimpel'son, V. and R. Kapelyushnikov (2004), "Rynok truda: Rossiiskie mify i rify", Vedomosti, 28 and 29 September.

Goetz, K. (2001), "Making Sense of Post-Communist Central Administration: Modernization, Europeanization or Latinization”, Journal of European Public Policy 8:6 (December). 
GPK (2002). ‘Federal’nyi zakon RF ot 14.11.2002 № 138-FZ “Grazhdanskii protsessual’nyi kodeks Rossiiskoi Federatsii”'.

Granville, Brigitte (1995), The Success of Russian Economic Reforms (London: RIIA).

Gray, C. and A. Gelb (1991), The Transformation of Economies in Central and Eastern Europe: Issues, Progress and Prospects, Policy Research Series no. 17 (Washington, DC: World Bank).

Greif, A. (2005), "The Emergence of Institutions to Protect Property Rights", in C. Menard and M. Shirley (eds), Handbook on New Institutional Economics (London: Kluwer).

Gurvich, E. (2005), 'Ydvoenie VVP: Pravitel'stvo bessil'no', Vedomosti, 25 January.

Hainsworth, R., O. Yeremenko and S. Tubin (2001), “Rossiiskie banki: sektor ili sistema?”, Rynok tsennykh bumag, May.

Hellman, J. (1998), "Winners Take All: The Politics of Partial Reform in Postcommunist Countries", World Politics 50:2.

Huskey, E. and A. Obolonsky (2003), “The Struggle to Reform Russia's Bureaucracy”, Problems of PostCommunism 50:4 (July-August).

IEA (2005), Russian Electricity Reform: Emerging Challenges and Opportunities, International Energy Agency, Paris.

IMF (1992), The Economy of the Former USSR in 1991, International Monetary Fund, Washington.

Kharas, H., B. Pinto and S. Ulatov (2001), "An Analysis of Russia's 1998 Meltdown: Fundamentals and Market Signals," Brookings Papers on Economic Activity, 1:1-62.

King, R. G. and R. Levine (1993), "Financial Intermediation and Economic Development", in Colin Mayer and Xavier Vives (eds), Financial Intermediation in the Construction of Europe, CEPR, London.

Koivu, T. (2002), "Does financial development affect economic growth in transition countries?" BOFIT discussion paper No. 14/2002 (Helsinki: Bank of Finland).

Kornai, J. (1986), “The Soft Budget Constraint”, Kyklos 39:1.

Lambert-Mogiliansky, A., C. Sonin and E. Zhuravskaya (2000), "Capture of Bankruptcy: A Theory and Evidence from Russia", RECEP Working Paper No.2000/3 (Moscow).

Levine, R. (1997), "Financial Development and Economic Growth: Views and Agenda", Journal of Economic Literature 35:2, June.

Levine, R. and S. Zervos (1998), "Stock Markets, Banks, and Economic Growth”, American Economic Review 88:3, June.

Nunberg, B. (1999), The State After Communism: Administrative Transitions in Central and Eastern Europe (Washington: The World Bank). 


\section{ECO/WKP(2005)17}

“Ob arbitrazhnykh sudakh” (2003). Federal'nyi konstitutsionnyi zakon RF ot 04.07.2003 № 4-FKZ ‘O vnesenii izmenenii i dopolnenii v federal'nyi konstitutsionnyi zakon "Ob arbitrazhnykh sudakh v Rossiiskoi Federatsii"”.

OECD (1995), OECD Economic Surveys: Russian Federation (Paris: OECD).

OECD (2001), “A Decade of Trade Liberalisation in Transition Economies”, Paris, 11 May.

OECD (2002), OECD Economic Surveys: Russian Federation (Paris: OECD).

OECD (2004a), OECD Economic Surveys: Russian Federation (Paris: OECD).

OECD (2004b) OECD Investment Policy Reviews: Russian Federation: Progress and Reform Challenges, Paris, December.

OECD (2004c), Enhancing Trade Openness Through Regulatory Reform in Russia, Paris, February.

“O statuse” (2001), Federal'nyi zakon RF ot 15.12.2001 № 169-FZ 'O vnesenii izmenenii i dopolnenii v federal'nyi zakon "O statuse sudei v Rossiiskoi Federatsii”'.

Pinto, B., V. Drebentsov and A. Morozov (2000), "Give Growth and Macroeconomic Stability in Russia a Chance: Harden Budgets by Eliminating Nonpayments", Economics of Transition, 8:2, July.

Pittman, R. (2001), "Vertical Restructuring of the Infrastructure Sectors of Transition Economies" (background paper for World Development Report 2002: Institutions for Development).

Rajan, R. and L. Zingales (1998), “Financial Dependence and Growth”, American Economic Review 88:3, June.

Shleifer, A. and R. Vishny (1993), “Corruption” NBER Working Paper 4372, May.

Shleifer, A. and Treisman, D. (2000). Without a Map: Political Tactics and Economic Reform in Russia (Cambridge, MA: MIT Press).

Sinel'nikov, S. (1995), "The State of Public Finance, Fiscal Policy and the Budget in Russia", in Michael McFaul (ed.), Privatisation, Conversion, and Enterprise Reform in Russia, Westview Press, Boulder.

Solnick, S. (1998). Stealing the State: Control and Collapse in Soviet Institutions (Boston MA: Harvard University Press).

Tadesse, S. (2001), "Financial Architecture and Economic Performance: International Evidence", William Davidson Working Paper 449, August.

Tompson, W. (1998), “Russia's 'Ministry of Cash': Sberbank in Transition”, Communist Economies \& Economic Transformation 10:2, June.

Tompson, W. (1999), "The Price of Everything and the Value of Nothing? Unravelling the Workings of Russia's "Virtual Economy"”, Economy and Society 28:2, May. 
Tompson, W. (2000), "Nothing Learned, Nothing Forgotten: Restructuring without Reform in Russia's Banking Sector", in Stefanie Harter and Gerald Easter (eds), Shaping the Economic Space in Russia, Aldershot, Ashgate.

Tompson, W. (2001), "Judicial Reform Moves forward in Russia", International Company and Commercial Law Review 12:7-8, July/August.

Tompson, W. (2002), "Russia Amends Law on Joint-Stock Companies", International Company and Commercial Law Review 13:1, January.

Tompson, W. (2003), "What Kind of 'Financial Safety Net' for Russia? Russian Banking Reform in Comparative Context", Post-Communist Economies 16:2, June.

Tompson, W. (2004), "Banking Reform in Russia: Problems and Prospects", OECD Economics Department Working Paper No. 410, November.

Voslensky, M. (1984), Nomenklatura: The Soviet Ruling Class, An Insider's Report (New York: Doubleday).

Woodruff, David (1996), 'Beyond the Rouble: The Politics of Monetary Consolidation in Russia', paper presented at the AAASS Annual Convention, Boston, MA, November 1996.

Woodruff, David (1999), Money Unmade: Barter and the Fate of Russian Capitalism (Ithaca: Cornell University Press).

World Bank (2004), Russia: Transition Meets Development, Country Economic Memorandum for the Russian Federation (Moscow: The World Bank), April. 


\section{WORKING PAPERS}

The full series of Economics Department Working Papers can be consulted at www.oecd.org/eco/Working_Papers/

429. Assessing the OECD Job Strategy: Past Developments and Reforms (May 2005) Nicola Brandt, Jean-Marc Burniaux and Romain Duval

428. Ageing, Welfare Services and Municipalities in Finland (May 2005) Jens Lundsgaard

427. The Impact of Structural Policies on Trade-Related Adjustment and the Shift to Services (April 2005) Per Mathis Kongsrud and Isabelle Wanner

426. Product Market Competition and Economic Performance Iceland (April 2005) Thomas Laubach and Michael Wise

425. Enhancing Brazil's Regulatory Framework for Network Industries: The Case of Electricity, Oil and Gas, and Water and Sanitation

(April 2005) Edmar Almeida and Nanno Mulder

424. Education Attainment in Brazil: The Experience of FUNDEF (April 2005) Luiz de Mello and Mombert Hoppe

423. Estimating a Fiscal Reaction Function: The Case of Debt Sustainability in Brazil (April 2005) Luiz de Mello

422. Product Market Competition and Economic Performance in the Netherlands (April 2005) Maria Maher and Michael Wise

421. Product Market Competition and Economic Performance in Canada (April 2005) Maria Maher and Jay Shaffer

420. The Impact of Ageing on Demand, Factor Markets and Growth (April 2005) Joaquim Oliveira Martins, Frédéric Gonand, Pablo Antolin, Christine de la Maisonneuve and Kwang-Yeol Yoo.

419. Product Market Regulation in OECD Countries: 1998 to 2003 (February 2005) Paul Conway, Véronique Janod and Giuseppe Nicoletti

418. Reforming Turkey's Public Expenditure Management (February 2005) Rauf Gönenç, Willi Leibfritz and Erdal Yilmaz

417. Fiscal Gimmickry in Europe: One-Off Measures and Creative Accounting (February 2005) Vincent Koen and Paul van den Noord

416. Getting the Most out of Public Sector Decentralisation in Japan (January 2005) Isabelle Joumard and Tadashi Yokoyama

415. Structural Policy Reforms and External Imbalances (January 2005) Mike Kennedy and Torsten Sløk

414. The Jobs Challenge in Poland: Policies to Raise Employment (January 2005) Andrew Burns and Przemyslaw Kowalski 
413. Product Market Competition and Economic Performance in Finland (December 2004) Jens Høj and Michael Wise

412. Oil Price Developments: Drivers, Economic Consequences and Policy Responses

(December 2004) Anne-Marie Brook, Robert Price, Douglas Sutherland, Niels Westerlund and Christophe André

411. Wealth Effects on Money Demand in EMU: Econometric Evidence (November 2004) Laurence Boone, Fanny Mikol and Paul van den Noord

410. Banking Reform in Russia : Problems and Prospects (November 2004) William Tompson

409. Public Expenditure in France (November 2004) Andrew Burns and Alessandro Goglio

409 La gestion des dépenses publiques en France (Novembre 2004) Andrew Burns et Alessandro Goglio

408. Russian Industrial Restructuring: Trends in Productivity, Competitiveness and Comparative Advantage (October 2004) Rudiger Ahrend

407. Improving the Capacity to Innovate in Germany (October 2004) Andrés Fuentes, Eckhard Wurzel and Margaret Morgan

406. Tax Treatment of Private Pension Savings in OECD Countries and the Net Tax Cost per Unit of Contribution to Tax-Favoured Schemes (October 2004) Kwang-Yeol Yoo and Alain de Serres

405. The Reform of the Health Care System in Portugal (October 2004) Stéphanie Guichard

404. Accounting for Russia's Post-Crisis Growth (October 2004) Rudiger Ahrend

403. Restructuring Russia's Electricity Sector: Towards Effective Competition or Faux Liberalisation? (October 2004) William Tompson

402. Russia's Gas Sector: The Endless Wait for Reform? (September 2004) Rudiger Ahrend and William Tompson

401. One Money, One Cycle? Making Monetary Union a Smoother Ride (September 2004) Peter Hoeller, Claude Giorno and Christine de la Maisonneuve

400. Modelling Cyclical Divergence in the Euro Area: The Housing Channel (September 2004) Paul van den Noord

399. Product Market Competition and Economic Performance in Korea (August 2004) Yongchun Baek, Randall Jones and Michael Wise

398. Product Market Competition and Economic Performance in the United States (July 2004) Hannes Suppanz, Michael Wise and Michael Kiley

397. Saving Behaviour and the Effectiveness of Fiscal Policy (July 2004) Luiz de Mello, Per Mathis Kongsrud and Robert Price 